\title{
WOMEN AND THE SECOND ESTATE IN 16TH CENTURY ZAMBEZIA: GENDERED POWERS, A 'PUPPET' AFRICAN QUEEN AND SUCCESSION IN VAKARANGA SOCIETY, 1500-1700
}

\author{
A Thesis \\ presented to \\ The Faculty of California Polytechnic State University, \\ San Luis Obispo
}

\author{
In Partial Fulfillment \\ of the Requirements for the Degree \\ Master of Arts in History \\ by \\ George Gregor Levin
}

October 2013 
(C) 2013

George Gregor Levin

ALL RIGHTS RESERVED 
COMMITTEE MEMBERSHIP

TITLE: Women and the Second Estate in 16th Century Zambezia: Gendered Powers, a 'Puppet' African

Queen and Succession in vaKaranga Society, 15001700

AUTHOR: $\quad$ George Gregor Levin

DATE SUBMITTED: October 2013

COMMITTEE CHAIR: $\quad$ Matthew Hopper, PhD

Associate Professor of History

COMMITTEE MEMBER: Thomas Trice, PhD

Associate Professor of History

COMMITTEE MEMBER: John Oriji, PhD

Associate Professor of History 


\begin{abstract}
Women and the Second Estate in 16th Century Zambezia: Gendered Powers, a 'Puppet' African Queen and Succession in vaKaranga Society, 1500-1700

George Gregor Levin
\end{abstract}

Women in vaKaranga society of the 15th to 17 th centuries have been portrayed as oppressed by an "extremely patriarchal" system, but the reality, while still fitting the simple classification of a 'patriarchal' monarchy, indicates quite a bit more negotiation of gendered powers than women, as a class, experienced in the Mediterranean or East Asia. The vaKaranga were the architects of Great Zimbabwe, the capital of a growing state, colonizing their cousins of the Zambezi river, which their Kusi-Mashariki Bantu forefathers had traversed southward a millennium before. Civil war had (apparently) split one nation into two states, Mutapa (Monomotapa) and Khami (Torwa, Toroa, Changamire) immediately before Portuguese ships arrived at Sofala in 1502. Statements like "women are dust, one does not count dust" have been used to illustrate the traditional social outlook of the Shona, descendants of the vaKaranga and a major population in present-day Zimbabwe, Zambia, Malawi and central Moçambique. However, close reading of early Portuguese-language sources on women in vaKaranga society suggests that, prior to influence from these original European colonists, vaKaranga women negotiated everyday and political power in a near-even exchange with men, predicated on the imbalance of power women held in the metaphysical dimension, their control of industries from gold production to staple crop production and a strategy for minimizing economic risk for a king transacting a brideprice or 'rovora' exchange. In this, vaKaranga women are exceptions to the theory that societies must become more gender imbalanced as they begin to form classes and state-level monarchies.

Keywords: Women, Shona, vaKaranga, Gender, Power, Zambezi, Zambezia, zimbabwe, "Great Zimbabwe," Mutapa, Monomotapa, Khami, Torwa, Toroa, Changamire, Sofala, Danda, Dande, Sedanda, Teve, Quiteve, Barwe, Mureche 


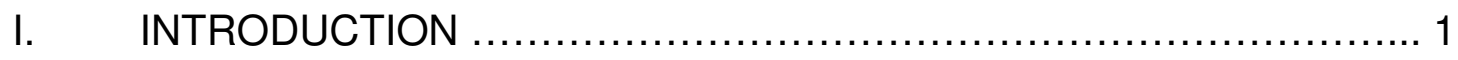

II. PART I - LITERATURE REVIEW ..................................... 17

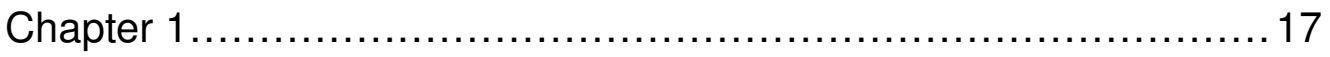

A. General History of the vaKaranga .......................... 18

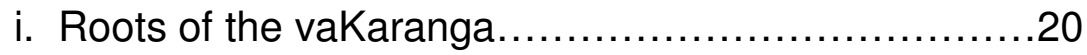

ii. Geography and Economy............................ 20

iii. Emergence of a Distinctive Culture....................23

iv. vaKaranga Political and Social Organization...........23

v. Life in dzaKaranga................................. 28

Chapter 2: Women in Precolonial Africa.................................. 37

Chapter 3: vaKaranga Women Prior to European Contact.............. 41

A. Economic Roles............................................ 42

B. Marriage, Family and Reproduction....................... 45

C. Access to, and Control Over, Space......................... 50

D. Women in Religious Life................................... 53

E. Women in Political Life....................................... 57

Chapter 4: Primary Literature Review and Methodology................6 63

III. PART II - THE BALANCE OF GENDER POWER AMONG VAKARANGA PRIOR TO EUROPEAN CONTACT: HISTORICAL

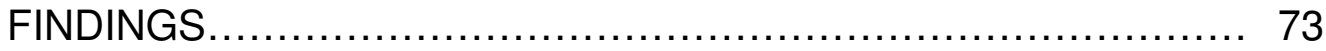

Chapter 5: Women's Roles in the Economy......................... 74

Chapter 6: Marriage, Family and Reproduction........................81 
Chapter 7: Women's Access to, and Control Over, Space............. 89

Chapter 8: Women in Religious Life............................... 97

Chapter 9: Women in vaKaranga Political Life.........................100

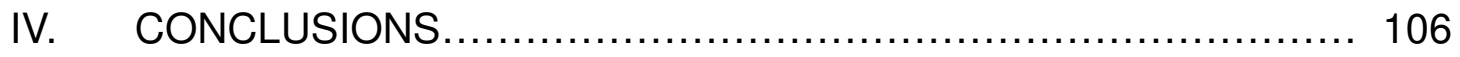

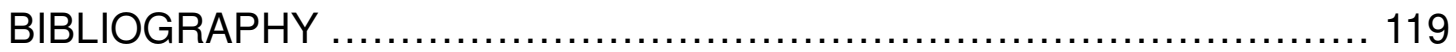




\section{LIST OF FIGURES}

Figure $\quad$ Page

1. The Dry Masonry Walls of the Great Enclosure Complex at Great Zimbabwe. Center-left is the Masterwork 'Conical Tower' Structure... 4

2. Overview of the Great Enclosure and Nearby Ruin Complexes at Great Zimbabwe.................................................. 5

3. Southern Africa Showing the Origins of the vaKaranga ................ 19

4. Cities and States Mentioned Throughout This Thesis. (The coastal states do not observe the color-coded chronology: all are from the

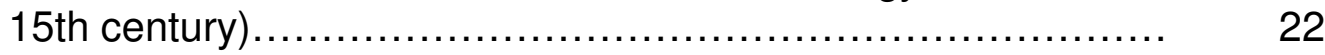




\section{Introduction:}

[Italics are editorial, a speed-reading aide]...for it is a law that no prince can enter the palace where they [the widows of the king] are without their permission, or take possession of the kingdom without their consent, and whoever enters by violence and takes possession against their will loses his right of succession to the kingdom. No one has the power to oppose the election made by the wives, as will be seen by the following example.

Near the kingdom of Quiteve is another of which Sedanda is king, the laws and customs of which are very similar to those of Quiteve, all these Kaffirs being of the same nation, and these two kingdoms having formerly been one, as I shall relate hereafter...Sedanda being dead, the prince whom he had chosen in his life would have entered the palace and seated himself with the wives of the former king, in the usual place where the ceremony of taking possession is gone through, as I have described. But things fell out very differently from what he expected, for the king's wives had great aversion to him, on account of his evil condition and other defects which they found in him. In the night therefore they secretly summoned another prince, upon whom they had fixed their eyes as more skillful and more pleasing to them, and seated him with them in the king's public palace...But [the new king] did not remain long in peace, for the prince who had fled was very powerful and was looked upon as the successor of the dead king. He assembled a large force, and came with violence to take possession of the kingdom, forcing an entrance to the palace in defiance of the king's wives, at which all were amazed, for none may enter there by force, and this action of his was sufficient to cause all his party to desert him and side with the women and the king whom they had elected, so that the rebel was forced to flee and never raised his head again.

Fr. João dos Santos, Ethiopia Oriental, 1:6, in ed. \& trans. George Theal, Records of South-Eastern Africa: Collected in Various Libraries and Archive Departments in Europe VII, (London: William Clowes and Sons, 1899-1903), 193.

Sometime in the last quarter of the fifteenth century, perhaps circa 1480 C.E., Mureche of clan Nzou-Samanyanga, a 'Princess' of Mutapa, the dominant power in northern present-day Zimbabwe, married Chimupore, a son of quiTeve, sovereign of Teve. ${ }^{1}$ Teve, Danda and a third state, Barwe, the ethnically foreign buffer state most directly between the port of Sofala and the territory of the

\footnotetext{
${ }^{1}$ David Beach, The Shona and Zimbabwe 900-1850: An Outline of Shona History (London: Heinemann, 1980), 163.
} 
mWene we Mutapa (the king of Mutapa), which Mureche and Chimupore proceeded to annex on behalf of their shared vaKaranga ethnic nation, were ruled by a regime which negotiated power between gendered hierarchies, as we see in the succession of Danda, above, in which the entire 'college' of the dead king's widows united against the college of elders (or male nobles, more likely) to deny the succession to one man in preference of another. For Mureche, marrying her father's junior ally's son and receiving a dowry-against custom, which dictates a brideprice gift to the father of the bride—of sovereignty over a newly conquered territory, the position of 'puppet' queen over the most important trade route in her known world was an earned distinction given to her in preference to at least two of her brothers who received gifts of lesser territories. ${ }^{2}$

The ethnic name 'vaKaranga,' refers to a people who are not extinct, but no longer identify collectively with the name. They built several state-level societies in the highland regions of southern Africa, including monumental stonewalled communities exemplified by the Great Zimbabwe_rumored, mythologized and disputed for centuries. ${ }^{3}$ The proper name Karanga is used today to refer to only a portion of the ethnic group, who are now broadly known as Shona, or more appropriately vaShona. ${ }^{4}$ The word itself, karanga, is the root word for wife, and the symbolic usage in the title "Wife of the Sovereign," entitled the holder to status more exclusive and privileged than an English Knighthood. The history of the vaKaranga as a distinctive group can be traced to the third or fourth century

\footnotetext{
${ }^{2}$ Beach, Shona and Zimbabwe, 162-63.

3 Joseph Vogel, "'Ruins in a Wild Land," foreward to Innocent Pikirayi, The Zimbabwe Culture: Origins and Decline of Southern Zambezian States (Walnut Creek: AltaMira Press, 2001), xvi-xvii.

${ }^{4}$ The prefix va- signifies that the root noun is human and plural ( $\mathrm{mu}-$ or $\mathrm{m}$ - is singular).
} 
C. E. and this thesis examines women's place in vaKaranga society up to, and including, the moment of first contact with Europeans in January $1506 .{ }^{5}$

This thesis makes use of both secondary and archival sources to argue that vaKaranga women held a number of powers and rights which, while not all were unique in world history, collectively gave them substantial political power. This suggests, although more thorough research is needed, that while the basic classification of vaKaranga/Shona as a patriarchal society is accurate, the society as observed by the original Portuguese colonists of the region, at the very least, was significantly less male-dominated than the European observers' societies were. These colonists' own biases and misconceptions have demonstrably distorted the record; in fact, it was long into the twentieth century before any of the colonizers' societies came close to offering women as a group the opportunities apparent in the historical record of early-modern vaKaranga.

This study began as an attempt to humanize the early period of contact between the three major powers that came together in a peripheral trade port of the southern Indian Ocean on the eastern coast of Africa. The port of Sofala, a vital link in a trade route that extracted gold and ivory, among other products, from the interior in exchange for cotton, silk, glass beads and high-quality ceramics, had acquired enough notoriety in the Indian Ocean market that it was among the named places Vasco da Gama was ordered to find in the course of his historic voyage to India in 1498 . Although he was not successful in visiting

${ }^{5}$ Christopher Ehret, An African Classical Age: Eastern and Southern Africa in World History, 1000 B.C. to A.D. 400 (Charlotsville: University Press of Virginia, 1998), 226-27; Pero d'Anhaya, "An Order from Pero de Anhaia, Captain-Major of Sofala, to the King's Treasurers, 1506 January 7" in Antonio da Silva Rego, ed., Documentos Sobre os Portugueses em Moçambique e na África Central I, trans. T. W. Baxter (Lisbon: National Archives of Rhodesia and Nyasaland, 1962), 367. 
the port on that trip, subsequent fleets soon found the place and in 1505 a mission arrived from Lisbon with orders to establish a fort and trade factory there. ${ }^{6}$ This was done, not without some setbacks, and soon the Portuguese under the command of a 'Capitão-Mor,' Captain-General Pero d'Anhaya, were receiving ambassadors from sovereigns of the interior. ${ }^{7}$

Sofala was a contact zone where Swahili merchants from the African coastal north, at this time under the rule of the mercantilist Sultanate of Kilwa, a 'Shirazi' Muslim state, were hoping to secure control of the coast before the vaKaranga powers of the interior could organize sufficiently to project power

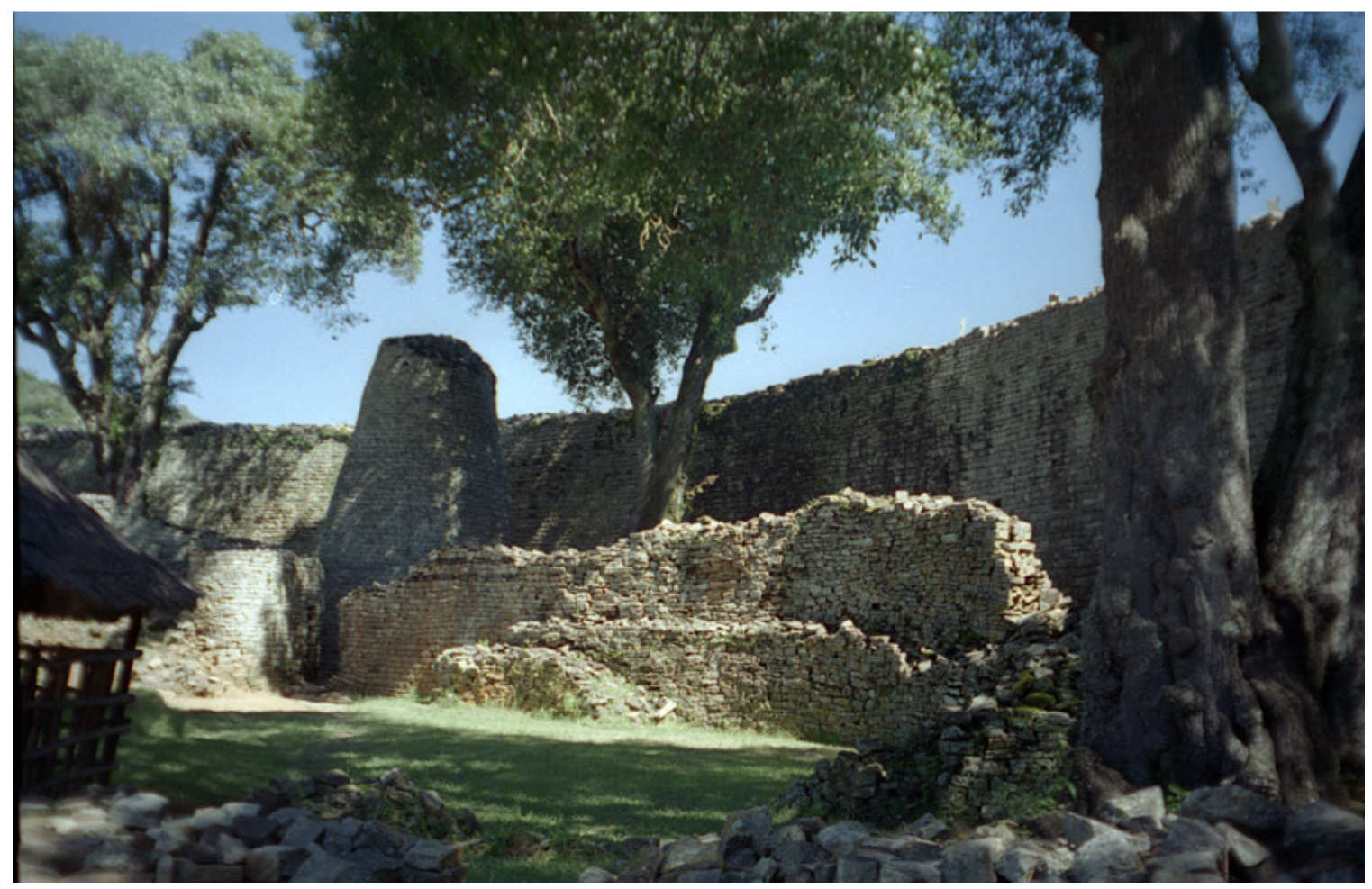

Figure 1: The dry masonry walls of the great enclosure complex at Great Zimbabwe. Center-left is the masterwork 'conical tower' structure

\footnotetext{
${ }^{6}$ João de Barros, Da Asia: Dos Feitos Que os Portugueses Fizeram na Conquista e Descubrimento das Terras e Mres do Oriente, 1:5:3, in Theal, Records VI, 169; Fernão Lopes de Castanheda, History of the Discovery and Conquest of India by the Portuguese, 2:1, in Theal, Records V, 376.

${ }^{7}$ Order from d'Anhaya to the King's Treasurers in da Silva Rego, Documentos, 367.
} 
there in substantial magnitude. ${ }^{8}$ The twin vaKaranga factions were pre-literate feudal kingships, in the midst of a catastrophic national schism. The name of the original nation centered on the Zimbabwe plateau is unknown, however the remains of a set of monumental stone-walled compounds scattered across the Zimbabwe Plateau are exemplified by the famed ruins of the Great Zimbabwe, which, with zimbabwe or dzimba dzimbahwe meaning 'houses of stone' or 'city,' roughly translates as 'The' City, 'The Great' City or more likely just 'the capital.'

At its height, the 'Great' yaKaranga state was a supreme monarchy

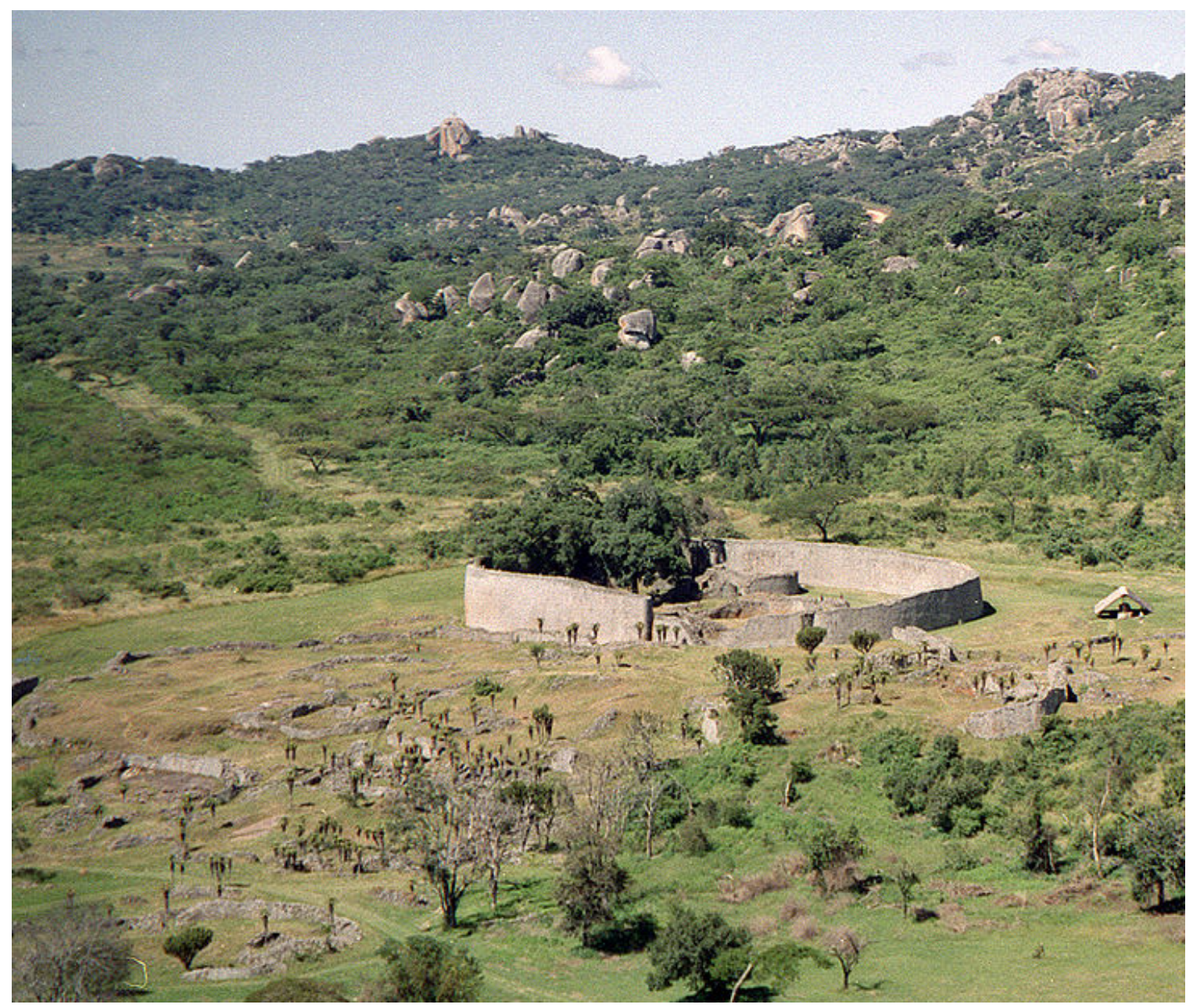

Figure 2: The great enclosure and nearby ruin complexes at Great Zimbabwe

\footnotetext{
${ }^{8}$ de Barros, Da Asia, 1:8:6 in Theal, Records VI, 240-42.
} 
comparable in social, political, economic and technological development to the 'Homeric' or 'Heroic' age cities at the heart of the conflict depicted in 'The Illiad,' composed in the era immediately prior to the diffusion of writing, and written down in the first wave of stories adapted to the new technology. ${ }^{9}$ A more conservative estimate of the 'height' of 'development' in southern Africa prior to da Gama's return to Portugal, which capped the first decade in which men of a single ethnic group had touched the lives of nearly every person on the planet, would put the vaWene of the Great Zimbabwe at the dawn of this 'Heroic' Era rather than at Agamemnon's and Priam's shared climax. The cultural and technological comparisons are still very apt, however. ${ }^{10}$

The Portuguese came into the showdown at Sofala from a third vector, upsetting a delicate dance that had been building to a climax for four centuries and was likely to have come to a head of its own accord in the same century, had they not arrived. Their coincidental arrival, just before the real drama was to begin, exploded the situations of both the vaKaranga powers, caught with their pants down in a nasty intramural struggle, and the developing Swahili city/islandstates, also involved in a process of power breakdown and reconsolidation in metahistorical preparation for the greater challenge of inter-regional rivalry.

When I began this project, I hoped that drawing portraits of three mid-level players in this nexus of Old World societies would shine a new light on one of the

\footnotetext{
${ }^{9}$ For countries and other physical places (as in dzimba dzimbahwe p. 4), a singular i- is paired with plural dzi-, but because this changes to ya- and dza- when the subject is in the past, the most appropriate name for the state in question is apparently 'Great yaKaranga' rather than 'Great Zimbabwe,' which, as I said, means simply 'the Capital.'

10 '-wene' has been the root word for 'sovereign' and now 'owner,' for the past five hundred years, although there is no direct evidence to prove it did not change with the fall of the Great Zimbabwe.
} 
most important historical events in world history, the dawn of the Modern Age. The superficial story of this historical moment seemed to supply two personalities for the triptych out of hand, and it was expected that there would be scant evidence for a specific actor to be named in the case of the third.

D'Anhaya developed a nemesis in the commonly characterized 'Sheikh' of Sofala, said (by the official history of Kilwa) to be the nephew of the Sultan of Kilwa and to have established political independence from his uncle in the interval between Sancho de Tovar's 1502 'discovery' of the port and d'Anhaya's 1505 arrival. ${ }^{11}$ I hypothesized that an agent of the mWene we Mutapa, the dominant power in the immediate interior, had existed, unnamed in the documents, but counterpart to the other two in that (whoever they were) they'd been active in the import/export trade through Sofala. If the portrait of such a person could be filled in around the edges, I thought, a sort of informative silhouette of the mainlander would emerge.

This overly ambitious project began crumbling almost before it began. It soon became clear that the sovereign at Sofala likely was not Swahili, nor ever directly ruled by Kilwa. ${ }^{12}$ It also became obvious almost immediately that to combine a story of the clash of three cultures with microhistories of three individuals would fill far too many pages for the scope of the project at hand, particularly given the wealth of information that would have to be explored with regard to the Portuguese paradigm in particular.

\footnotetext{
${ }^{11}$ S. A. Strong, ed., "Kitab al-Sulwa fi akhbar Kulwa," Journal of the Royal Asiatic Society, LVII (1895); Castanheda, Discovery and Conquest of India, 2:10, 2:11 \& 2:29 in Theal, Records V, 384-89, 391-94.

${ }^{12}$ See in particular Castanheda's account, op cit. above and Gaspar Correa's Lendas da India in Theal, Records II, 36-41.
} 
In the meantime, however, I also discovered that finding at least a real name and rank for a muKaranga (mu- is the singular human prefix) mid-level authority figure might be possible based on the skeletal political histories reconstructed in David Beach's The Shona and Zimbabwe. ${ }^{13}$ A contrast was also beginning to appear between the Catholic and Muslim maritime societies on the one hand, whose representatives to the event necessarily remained pretty fixed, and the metaphysically disparate vaKaranga, for whom the options were somewhat broader. Given this leeway, and a progressively more apparent divergence between the gender attitudes of the Abrahamic societies and the vaKaranga worldview, the focus devolved increasingly on finding a female counterpart to the two male 'governors,' the Swahili Sheikh (who existed, though he likely was not the same person as the "Rey," so-called by numerous Portuguese sources, and in explicit distinction from "Xeque" on one occasion) and the Portuguese Capitão-Mor. ${ }^{14}$

In the end, the tri-cultural look at the event had to be set aside, and even the idea of a 'portrait' look at a single muKaranga in societal context was abandoned in favor of a more straightforward women's history. The exercise in self-control, however, did bear some other fruit. Not only did Beach's synthesis of the traditional histories yield a number of useful candidates for the thesis that some counterpart to the maritime 'governors' existed in proximity to Sofala, it

\footnotetext{
${ }^{13}$ Beach, Shona and Zimbabwe.

${ }^{14}$ This sovereign is also described as a "heathen kaffir" by Correa, who describes the sovereign of Sofala immediately after referring to the sovereign of Moçambique as "the sheikh [who] gave [Pedro Affonso] a good pilot who knew the course. The chief captain sent a large present to the king, who was a heathen Kaffir that in Sofala already had knowledge of our affairs." Correa, Lendas da India in Theal, Records II, 28-29.
} 
eventually offered a named woman to fill that role. ${ }^{15}$ Her story, a woman puppetsovereign over the mWene we Mutapa's most direct trade route to Sofala, offers compelling evidence that vaKaranga women, as a class, held formal power and higher status than more familiar societal counterparts, where even women who achieved power did so as exceptions to the rule. It was, in the process of researching this thesis, the final element in driving home the conviction that women's place in pre-modern vaKaranga society has been badly misunderstood.

This conviction was built through close readings of the primary sources, but also on a critique of the secondary sources and a gendered reading of interdisciplinary material. The secondary material was the most problematic, and is the focus of this thesis, although each group had its difficulties, as a review of the literature below will show. A group of scholars, beginning with Elizabeth Schmidt, followed by a group of self-proclaimed "radical feminists," represented in South-East Africa by Cindy Courville, who acknowledges a direct inspiration from Schmidt, offered biased representations of gender that exaggerated male power or deemphasized women's positions in vaKaranga society. ${ }^{16}$

The theoretical framework of these scholars is by no means a monolithic one espoused by all feminists, nor is it uncommon for two new fields of history to create a small echo chamber in which an idea is smoothed across all categories by a small collection of scholars enamored of one particular field's theory over the other's, however it's important not to let small oversights balloon into larger

\footnotetext{
${ }^{15}$ Beach, Shona and Zimbabwe, 163.

${ }^{16}$ Elizabeth Schmidt, Peasants, Traders and Wives: Shona Women in the History of Zimbabwe, 1870-1939 (London: Heinemann, 1992) and Cindy Courville, "Re-Examining Patriarchy as a Mode of Production: The Case of Zimbabwe" in eds. Stanlie James and Abena Busia, Theorizing Black Feminisms: The Visionary Pragmatism of Black Women (London: Routlege, 1993), 31.
} 
misrepresentations by going uncriticized, even if there is some delicacy in a younger, male scholar criticizing laurelled, not to mention well-published, women scholars on gender theory about women. Caroline Walker Bynum points out, in defense of "postmodern or poststructuralist" subfields of history, including "new subjects such as feminism, gender, post-colonialism, and cultural studies," the commonality of minor or superficial flaws in fundamentally sound and useful schools of thought for interpreting history and this thesis does not propose to reject postmodernism wholesale because of the single bad assumption disguised as a minor premise exposed by its conclusions.

The attitude of its author is that poststructuralists have been, if the reader can forgive the pun, obsessing too long about the foundation where the 'structure' used to be, while the poststructuralism critics Bynum is responding to, to the extent that I speak for them in this, feel comfortable with the amount of information available about past ways of looking at the world and are anxious to begin testing the postmodern mantra that, as Bynum puts it, all information is "always interpreted and interpretable" with new, more nuanced, and if not less biased, then at least more self-conscious, theories for contextualizing history. ${ }^{17}$

So, while some gender scholars, like Natalie Zemon Davis, have displayed the dispassion and sense of nuance that more ardent philosopherscholars like Courville overlook when discussing an issue as near to their sense of identity as gender, whatever 'second turn' post-structuralism critics advocate or look for is a turn away from history like Davis's triptych microhistories, Women on

\footnotetext{
${ }^{17}$ Caroline Walker Bynum, "Perspectives, Connections \& Objects: What's Happening in History Now?" Deadalus 138.1 (Winter 2009), 72-74.
} 
the Margins: Three Seventeenth Century Lives, which explores the world connecting the three subjects to one another so, forgive me, timidly, as to have very little substantial to say about the world in which those subjects lived. ${ }^{18}$ We are left with only vivid flashes of the women in their real context, not explored, and with no real sense of why any of the research matters or what these three women represent. All of the information synthesized about them at great expense of time, by a well-written scholar, loses out (in my mind) by the absence of the expert opinions and insight of the scholar "on the scene," as it were. While little is left of the scholar's biases and oversights to criticize, this is arguably more a vice than a virtue, since much knowledge is to be gained from such debates.

Susan Kent, a gender scholar cited extensively in this thesis, but not among the small group responsible for the mischaracterization under discussion, makes a point of highlighting, in the introduction to her edited volume, what she calls "universalist... biological rather than cultural" perceptions of gender, echoing a theme common to the cultural relativist and social history philosophies that grew out of the 1960s intellectual fluorescence: that social causes and social explanations can always be found for human behavior. ${ }^{19}$ I do not understand what it is to be a woman, fighting for women's representation in the social story, but it seemed counter-intuitive for a contemporary scholar to Kent, claiming the mantle of feminist, then the dominant term over 'gender,' to downplay any women's power at any time. I, for one, find it fascinating to look at vaKaranga

\footnotetext{
${ }^{18}$ Natalie Zemon Davis, Women on the Margins: Three Seventeenth Century Lives (Cambridge: Harvard University Press, 1995), also Davis, "Women in the Crafts in Sixteenth-Century Lyon," Feminist Studies 8.1 (Spring 1982), 46-80.

${ }^{19}$ Susan Kent, "Gender and Prehistory in Africa," in ed. Susan Kent, Gender in African Prehistory (Walnut Creek: AltaMira Press, 1998), 12.
} 
society as potentially a 'world-system' metropole, however small the system, and potentially run on a much more gender-negotiated basis than in the dominant narrative of gender history worldwide. Courville's self-designation "radical" feminism implies a political application of the feminist theory, and while this radical conceptualization of women's oppression being universal worldwide may be false or propagandist, as I argue, I do not wish to lose track of the fact that we are focusing on a tiny portion of the pre-Modern world population to show this. In this case, however, it is the post-modern critique that proves particularly apt in suggesting that a 'universalist biological' characterization of human gender power dynamics would wrongly suggest a 'natural state' of male dominance.

This thesis was pursued as a history of Africa above all, however, with its early-modern setting and gender theme dictated by the primary documents. Had a different portion of the coast been chosen, and therefore a different time for a study of Africa as encountered by the Portuguese, with a different society under the microscope, it is likely some other aspect of the secondary literature would have been most obviously in need of revision.

As things stand, it was a woman, a feminist and a post-modernist scholar, and a good one, who elaborated a theory of women in Africa incorrectly over the vaKaranga, deceived by ambiguous terminology ('precolonial') and a language barrier (Portuguese), which masked the inconsistencies. This was compounded by a group of scholars who cited from the original scholar in building the case out further. I, who have not had occasion to study gender-historiographical methods except insofar as they intersect African historiographical methods (not negligable, 
but nevertheless), do not make any real attempt to show a complete gender outlook. Although I make various comparisons: a house of cards with queens always somewhere in the top row, but one king always at the peak; a zig-zag power structure, man, wives, inferior, inferior's wives; these are merely superficial assessments, not backed up by the research to suggest that they will hold up. My goal here, sadly, is merely a post-modern one: to show what is wrong with the assumptions made by previous scholars, not to suggest new ways of seeing rightly, which in this case I'm not qualified to do, had I the resources anyways. I can show what is wrong only because Africanist social science methods come up with a drastically different conclusion than the gender social science I have critiqued, but I can do no more here than show the discrepancy.

My thesis, that vaKaranga women in the century before and after they were first written about held positions of formal and substantial authority, collective rights and gendered powers unique in number, magnitude and duration, reflects my view that a study of women that focuses on the experiences of real and/or everyday women will provide a more accurate picture of vaKaranga society than a polemic designed to support some global argument shrinkwrapped with feminism. In pursuing a more faithful picture of the vaKaranga, I find a number of things indicated that advance knowledge in useful ways for the long term understanding of gender and gender dynamics.

For instance, there is an abiding theory that, because European societies and more familiar Asian ones by and large did so, societies transitioning from Late Stone Age nomadism to Early Iron Age sedentarism and on to more 
complex preliterate Feudalism must necessarily become more gender imbalanced as their wealth concurrently becomes more unequally distributed. ${ }^{20}$ vaKaranga society, clearly one of these preliterate Feudalist groups, does not seem to have done so to any great extent. At the time of first contact with Europeans, women held substantial positions of power: they spoke for their husbands the sovereigns of territories, they ran agricultural industries at a statewide level and they handled the treasury. Within 150 years of contact (during which outside cultural pressure was pushing against their power), they were sub-rulers comparable in stature to barons, counts or even dukes (note, I have intentionally compared them to the male European equivalents), with power to mete out capital punishment and no known formal superiors excepting their husband the ultimate sovereign. Women in the period under examination founded lineages, were deified as royal lineage spirits and may have been the chief rainmakers, the highest ceremonial position in vaKaranga religion.

Not all of these features are unique to vaKaranga culture, in fact, Michelle Marrese has demonstrated comparable levels of property rights among the women of the second estate in eighteenth century Russia, however this is in explicit contrast to a social and family role which she equates to Western Europe as a standard of global mainstream gender power balances. ${ }^{21}$ Deborah Hertz, too, has shown a moment of relative equal opportunity for elite women in eighteenth century Berlin, but this was conditioned on friendly Franco-Prussian

\footnotetext{
${ }^{20}$ Susan Kent, "Invisible Gender-Invisible Foragers," in Kent, Gender, 60, terms this "the model of the relationship between sociopolitical complexity and egalitarianism," explicitly "including gender equality" in this model.

${ }_{21}$ Michelle Lamarche Marrese, A Woman's Kingdom: Noblewomen and the Control of Property in Russia, 1700-1861 (Ithaca: Cornell University Press, 2002).
} 
relations, among other fleeting circumstances. ${ }^{22}$ It would appear that the collection of rights, responsibilities and powers held in common by vaKaranga women, or available to elite women, is unique (or certainly very rare) in number and/or durability worldwide, or at least among broadly comparable societies, which I would characterize as societies that experienced some version of the Old World metals and agricultural successions of 'ages.' It suggests, although certain avenues of exploration were beyond the ability of this study to confirm it, that a broader study of gender in traditional vaKaranga culture would show us a society substantially more balanced in terms of gender powers than those better documented societies in Europe and Asia which lie closer to the 'mainstream.'

Because of the nature of the literature in early-modern area studies, this thesis has been organized slightly differently from others. Much of the secondary literature is interdisciplinary and the original source of information fragments that are collected and applied here for the first time in a gender history for this place and period. Instead of a short literature review in advance of a lengthy examination of extensive primary source material, therefore, the secondary literature is used at greater length, occupying about half of the main section of the thesis. This is followed by a short discussion of the special problems and methods that attend an historical examination of a moment that straddles the divide between societal pre-literacy and the beginning of the historical record. The methods section also deals with the particular problems encountered in Portuguese-language sources on Africa. Finally, discussion of the original

\footnotetext{
${ }^{22}$ Deborah Hertz, "Salonières and Literary Women in Late Eighteenth Century Berlin" New German Critique 14 (Spring 1978), 97-108.
} 
historical research, that gendered information that is found exclusively in the primary documents, covers almost the other half of the main section.

The first chapter of the literature review is simply an introduction to the vaKaranga people as they have been reconstructed by archaeologists, cultural anthropologists, historical linguists, historians using traditional histories and those using conventional historiography. This, of itself, is a project meriting treatment at greater length, as it has been thirty years since the last general history of the vaKaranga/Shona was written, and there has never been a social history. ${ }^{23}$ The only recent book on the vaKaranga focuses on archeology. ${ }^{24}$

Chapter two is a short synopsis of the treatment of women and gender studies in Africa broadly, a discussion that blends far too many highly disparate societies together to have any value in less than encyclopedic treatment. Its purpose is to establish a framework by which the remaining discussions, which are specifically about vaKaranga women, can be structured. It finds five main classes of gender study on women in Africa: economics; marriage and family; access to and control over space; religion; and politics. Chapter three is subdivided into these sections and each is discussed in the context of vaKaranga women in the secondary literature as separately as it is possible to distinguish such overlapping concepts. Chapter four is the above-mentioned section on methodology, while chapters five through nine follow the same breakdown as chapter three in discussing primary source data on vaKaranga women, and chapter ten concludes.

\footnotetext{
${ }^{23}$ Beach, Shona and Zimbabwe.

${ }^{24}$ Pikirayi, Zimbabwe Culture.
} 


\section{Part I: Literature Review - Chapter 1:}

In constructing the history of women in a pre-modern, preliterate society, scholars rely on fragments from various disciplines. As such, this review draws widely, from not only historiography, but archeology, historical linguistics, and cultural anthropology. Of course, none of these is fully satisfactory or reliable.

Archaeological findings paint a partial picture, in this case undermined by wide-scale theft and destruction of remains by such "explorer-excavators" as Theodore Bent and Richard Hall; moreover, the commentary from such sources, while indispensable as the first written eyewitness accounts of the important ruins at the Great Zimbabwe, is undermined by blatant racism and prejudice. ${ }^{25}$ Based on his subsequent excavations, Randall-Maclver contended that it was the Shona who had created the Great Zimbabwe. ${ }^{26}$ This view was borne out by the findings of archaeologist Gertrude Caton-Thompson, whose conclusive evidence completed the formative stage of vaKaranga studies that has brought the study of Limpopo-Zambezi civilization out of myth and legend and into the realm of preliterate history. ${ }^{27}$ The archaeological record still lacks authoritative analyses and comprehensive catalogs of biological remains, excepting Richard Klein's study of large mammals, and of how culture is expressed in the archaeological record, however the essential human narrative is now more or less settled. ${ }^{28}$

\footnotetext{
25 James Theodore Bent, The Ruined Cities of Mashonaland: Being a Record of Excavation and Exploration in 1891 (London: Longmans, Green, and Co., 1896); Richard Nicklin Hall and W. G. Neal, The Ancient Ruins of Rhodesia: Monomotapae Imperium (London: Methuen \& Co., 1904). ${ }^{26}$ David Randall-Maclver, Medieval Rhodesia (Abingdon: Frank Cass \& Co., 1906).

${ }^{27}$ Gertrude Caton-Thompson, The Zimbabwe Culture: Ruins and Reactions (New York: Negro Universities Press, 1931).

${ }^{28}$ Richard Klein, "The Large Mammals of Southern Africa: Late Pliocene to Recent," in ed.
} 
Contemporary ethnography, meanwhile, faces the dilemma of how much may be extrapolated backwards in time. Oral sources such as the historical traditions collected by Beach or the folktales published by Tracey and Theal offer valuable evidence and are cautiously used, but their reliability has been challenged. ${ }^{29}$ The early written records by European travelers and colonists, too, are suspect; Innocent Pikirayi, author of the recent monograph on the subject, The Zimbabwe Culture: Origins and Decline of Southern Zambezian States, highlights the accuracy of the Portuguese records in some regard while acknowledging that they are "very biased in their depiction of the interior societies." ${ }^{30}$ Nevertheless, put together, the broad and abundant scholarship on the region has grown enough to draw a general picture of the vaKaranga at the time of the arrival of Europeans.

\section{General history of the vaKaranga}

To begin, and because the topic is of interest to a number of disparate specialized historian classes who needn't be particularly familiar with the vaKaranga or Shona already, a review of the general history of the people as a whole will be useful. Much of the ancient history of the vaKaranga rests, of course, on physical anthropology, including archeology. Unfortunately, as noted

Richard Klein, Southern African Prehistory and Paleoenvironments (Rotterdam: A.A. Balkema, 1984), 107-46.

${ }_{29}$ David Beach, The Shona and Zimbabwe 900-1850: An Outline of Shona History (London: Heinemann, 1980); George McCall Theal, Kaffir Folk-Lore: A Selection from the Traditional Tales Current Among the People Living on the Eastern Border of the Cape Colony (London: S. Sonnenschein, Le Bas \& Lowery, 1886); Hugh Tracey, The Lion on the Path: and Other African Stories (London: Routledge \& Kegan Paul, 1967): Beach, himself, Shona and Zimbabwe, 59-60, for instance, and Innocent Pikirayi, The Zimbabwe Culture: Origins and Decline of Southern Zambezian States (Walnut Creek: AltaMira Press, 2001), xxix, share these doubts.

${ }^{30}$ Pikirayi, Zimbabwe Culture, xxviii. 
above, this evidence is incomplete to say the least. Nevertheless, the archeology and its commentary, combined with historical linguistic studies and cultural anthropology, have allowed a mapping of the roots of these people back to at least the early first millennium of the common era. ${ }^{31}$

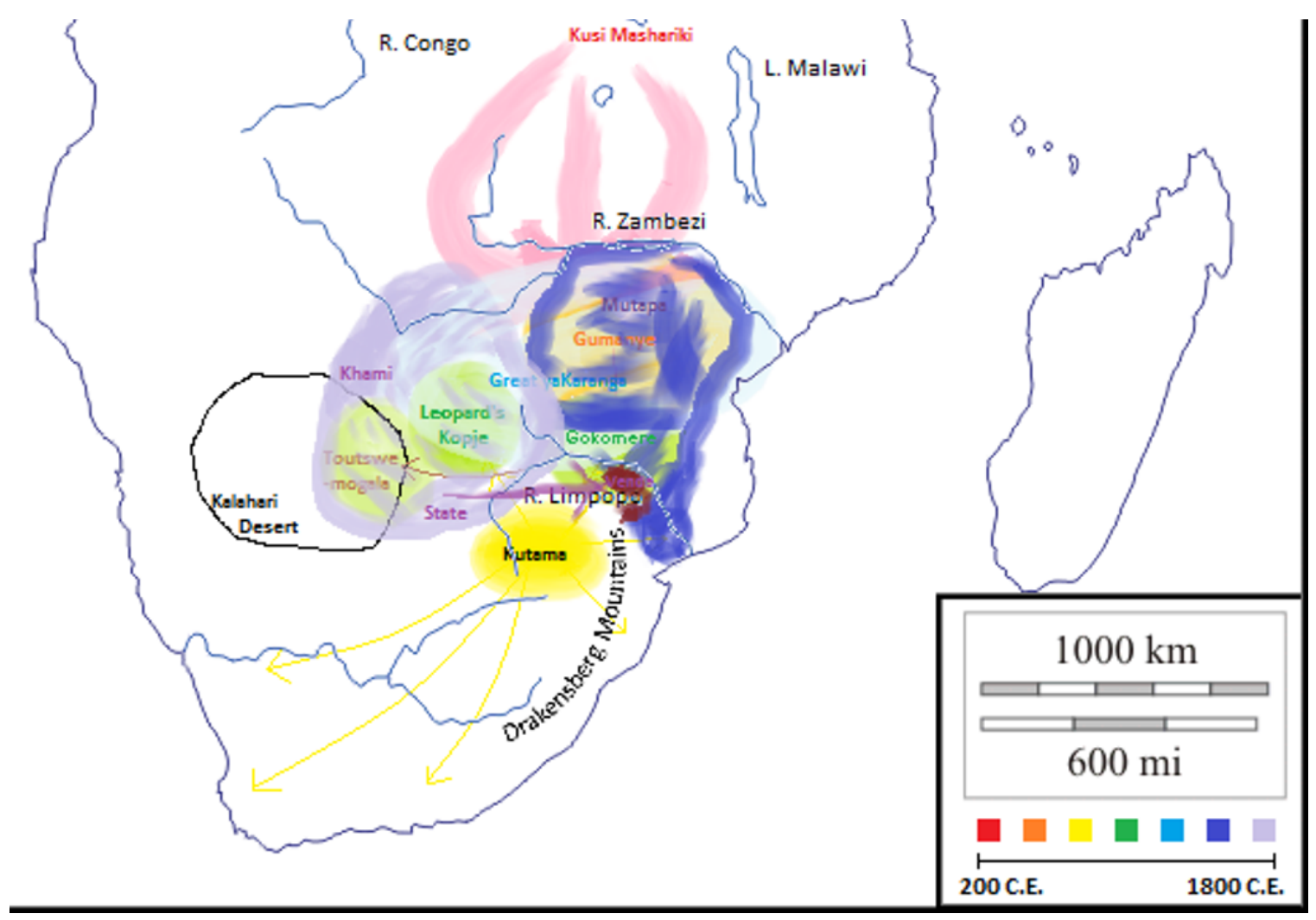

Figure 3: Southern Africa showing the origins of the vaKaranga.

${ }^{31}$ Christopher Ehret, An African Classical Age: Eastern and Southern Africa in World History, 1000 B.C. to A.D. 400 (Charlotsville: University Press of Virginia, 1998); Thomas N. Huffman, "Archaeology and Ethnohistory of the African Iron Age," Annual Review of Anthropology, vol. 11 (1982): 133-50; Adam Kuper, Wives for Cattle: Bridewealth and Marriage in Southern Africa (London: Routledge \& Kegan Paul, 1982); Susan Kent, ed., Gender in African Prehistory (Walnut Creek: AltaMira Press, 1998); William Rayner, The Tribe and Its Successors: An Account of African Traditional Life and European Settlement in Southern Rhodesia (London: Faber and Faber, 1962); Michael Gelfand, The African Witch: With Particular Reference to Witchcraft Beliefs and Practice Among the Shona of Rhodesia (Edinburgh: E \& S Livingstone, 1967); Martin Hall, The Changing Past: Farmers, Kings and Traders in Southern Africa, 200-1860 (Cape Town: David Philip, 1987); David Phillipson, The Later Prehistory of Eastern and Southern Africa (London: Heinemann, 1977); Peter Garlake, Great Zimbabwe (New York: Stein and Day, 1973). 
Roots of the vaKaranga

On a thousand-year scale, the history of the vaKaranga is the broader history of the Iron Age of southern Africa. ${ }^{32}$ The original inhabitants, as far as such a thing can be put into a category, can be described more or less accurately as an indeterminate succession of Khoisan speaking, stone-tool using, huntergatherers. ${ }^{33}$ Through this long-zoom lens we see a society composed of mainly Kusi-Mashariki peoples, who received a basic kit of iron age technology, diffused from some Eastern Sahelian-language speaking peoples in the Great Lakes region of East-Central Africa, before moving south. ${ }^{34}$ They displaced and partially absorbed the Khoisan-speaking Stone Age peoples of the ZambeziLimpopo region and then continued advancing south. ${ }^{35}$

\section{Geography and Economy}

The geographic and economic 'world' of the Zambezi-Limpopo region stretches across a plateau from one great river, the Zambezi, in the north, over a basin of rivers that drains that plateau to the south, and into the mountain valleys that break the terrain for a few hundred miles of rugged "highveld" ridges before smoothing out again into the broadening Northern Transvaal of the present-day Republic of South Africa ${ }^{36}$ The heights on the northern slope of the highveld are the inflection point on which the crest of the Bantu wave of families swept up over

\footnotetext{
${ }^{32}$ Ehret, African Classical Age, 209-42.

${ }^{33}$ Ehret, African Classical Age, 213.

${ }^{34}$ Ibid., 210.

${ }^{35}$ Ibid., 227.

${ }^{36}$ Innocent Pikirayi, The Zimbabwe Culture: Origins and Decline of Southern Zambezian States (Walnut Creek: AltaMira Press, 2001) xvi-xvii.
} 
the lip of the sub-continental ridge and splashed back down, spraying pioneers out into South Africa, but also starting a wave of counter-migration northward. ${ }^{37}$ Cultivating a settled lifestyle as had never been seen in the area, they developed a ceramic culture, 'Kutama ware,' built a localized economy based on copper, salt, iron and eventually tin mines in the mountains and began spreading in all directions from the Drakensberg. ${ }^{38}$ Makers of the descendent 'Gokomere' culture returned north into the Limpopo valley, where the abundant elephant habitat allowed them to inaugurate an export trade in ivory. ${ }^{39}$ The increased prosperity from long-distance trade stimulated the growth of state institutions, first at Bambandyanalo, then moving on to Mapungubwe and eventually shifting even further north to the site of the Great Zimbabwe. ${ }^{40}$ Finding that another metal, gold, in high demand to the far north, was available in small quantities throughout the Zambezi-Limpopo area, they soon took up that industry too. ${ }^{41}$ The Gokomere and their closest Kutama-kin, the Leopard's Kopje people, eventually grew into the vaKaranga, the forebears of today's Shona peoples.

For these vaKaranga, the known-world consisted of the farthest point visible from the north bank of the middle Zambezi to the highest ridge of the Drakensberg Mountains in the south, from the Kalahari edge and the Sowe salt pans in the west to the coast in the East. ${ }^{42}$ It included trade outlets to outworld

\footnotetext{
${ }^{37}$ Beach, Shona and Zimbabwe, 19-20.

${ }^{38}$ Revil Mason, "Background to the Transvaal Iron Age-New Discoveries in Olifantspoort and Broederstroom," Journal of the South African Institute of Mining and Metallurgy 74 (1974): 215; Michael Grant, "The Sourcing of Southern African Tin Artefacts," Journal of Archaeological Science 26, no. 8 (1999): 1112.

${ }^{39}$ Pikirayi, Zimbabwe Culture, 97-98, 107-16.

40 Ibid., 107-16.

${ }^{41}$ Garlake, Great Zimbabwe, 116; M. Hall, Changing Past, 96.

${ }^{42}$ Beach, Shona and Zimbabwe, 1.
} 


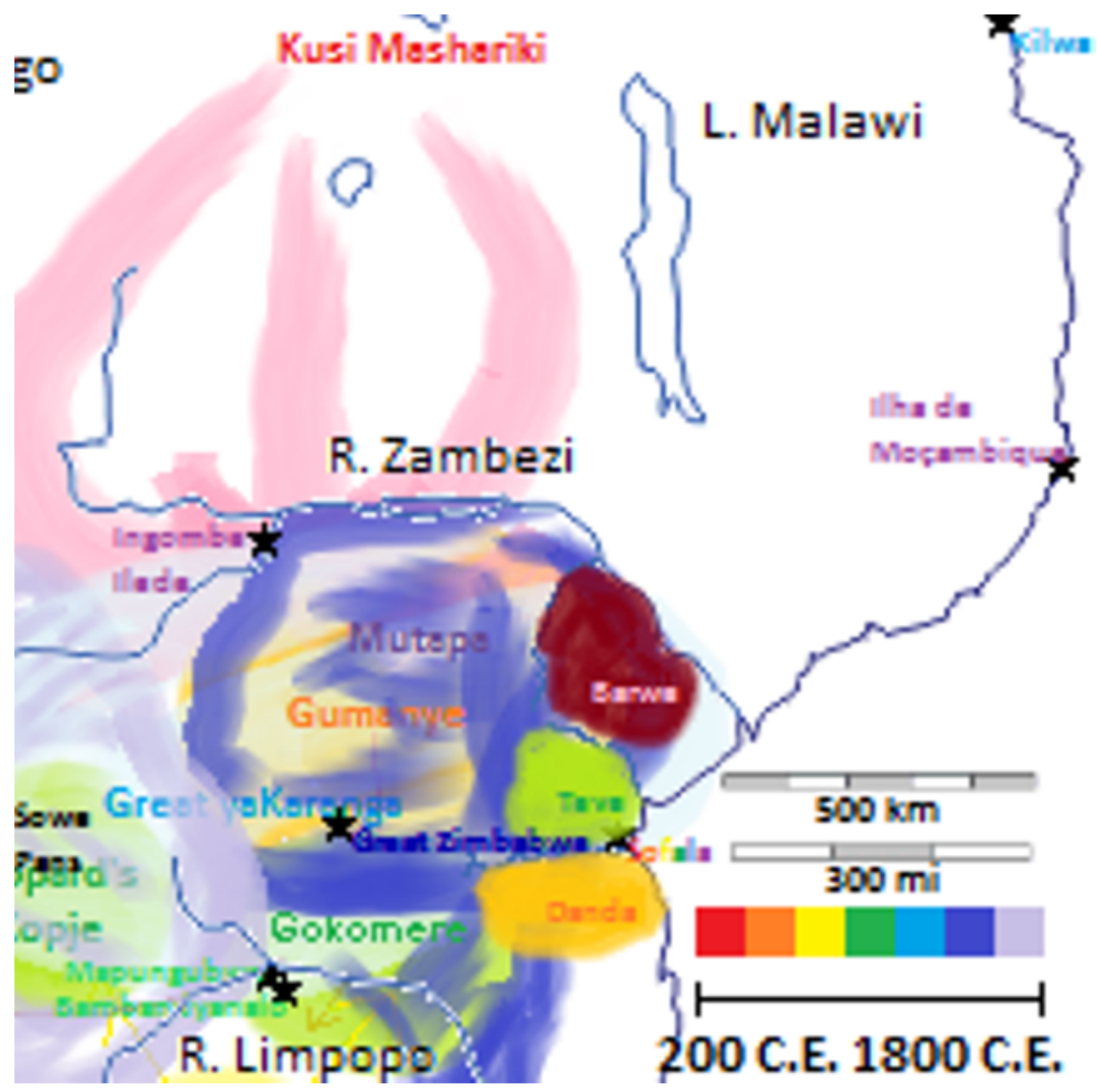

Figure 4: Cities and States Mentioned Throughout This Thesis. (The coastal states do not observe the color-coded chronology: all are from the 15th century) systems, in place of frontiers, for the most part. These are thought to be at the south-eastern sources of the Congo, the third cataract of the Zambezi above Ingombe llede, diffuse trade contacts with the Natal coast and, of course, the all important Swahili contact zone at the Sofala and Ilha de Moçambique coasts. ${ }^{43}$

\footnotetext{
${ }^{43}$ Pikirayi, Zimbabwe Culture, 110; Beach, Shona and Zimbabwe, 48-49; Tim Maggs, "The Iron Age South of the Zambezi," in Klein, Prehistory and Paleoenvironments, 354. No evidence exists that any muKaranga traveled beyond these limits and returned to speak of it prior to the moment
} 


\section{Emergence of a Distinctive Culture}

The Gokomere, the Leopard's Kopje people, and an allied/rival Zhizoware-making group, founded state-level societies based on corporately held clan wealth built from an aggregate of capital in a number of commodities, primarily ivory and cattle. ${ }^{44}$ Although the Gokomere's home territory had little in the way of the gold deposits that would become an important core of the region's exports, they came to dominate the region due to their position to the east of the other two peoples, which allowed them to interdict the export trade and siphon wealth at much lower cost than the original producers' investments. As their power spread, the cultures of the Leopard's Kopje in particular, but also the Zhizo-making Toutswemogala were consumed or obliterated by Gokomere varieties of ceramic and settlement layout. This suggests that both dependent states came to be eventually incorporated into the expanding yaKaranga state, and to some extent, presumably, the ethnic identity of the vaKaranga. By the time of European contact, the whole plateau and its drainage area north as far as the Zambezi river was governed by the social system these three peoples had developed. ${ }^{45}$

\section{vaKaranga Political and Social Organization}

The vaKaranga lived in circular huts, with conical thatch or palm roofs,

\footnotetext{
of first contact with the Portuguese. However, the memoirs of Buzurg ibn-Shahriyar tell of a coastal prince taken as a slave by treachery. He achieves emancipation, returns to his birthplace and is there to welcome his kidnapper, Buzurg, twenty years later when he is again storm-tossed on the Sofala coast. See: Buzurg ibn-Shahriyar, The Book of the Wonders of India: Mainland, Sea and Islands, trans. G.S.P. Freeman-Grenville (London: East-West Publications, Ltd., 1981).

${ }_{44}$ Pikirayi, Zimbabwe Culture, 109-10.

${ }^{45}$ Beach, Shona and Zimbabwe, 21.
} 
with a smoke gap between the top of the walls and the slope of the roof. ${ }^{46}$ Particularly large huts sometimes had extended roofs that covered a broad verandah, and a yard with vegetable garden and probably a small family granary was roughly closed off from other compounds in the settlement by brambled hedges or some other method. ${ }^{47}$

Dual, polarized spaces on a right-to-left axis characterized the metaphysical outlook of eastern Bantu society. Opposing spaces described polarized territories on a multidimensional pie-chart both within individual huts and covering whole settlements. Perpendicular to a genderized axis, which ran across the settlement from left to right, was an axis characterized by status which also carried connotations of profane/secular, dangerous/safe and public/private polarities. ${ }^{48}$ With circular huts distributed around a series of circular compounds, around a central ring and surrounded by the village's millet fields, a picture of everyday life emerges with concentric circles balanced on a disk of polar distinctions that defines the relationships of all things living and supernatural. ${ }^{49}$

This pattern continued at the regional and even the state level. The most important village in the area was home to the sub-chief, whose authority extended over a dunhu, translated by English colonists as 'ward. ${ }^{, 50}$ Dunhu, the

\footnotetext{
${ }^{46}$ Phillipson, Later Prehistory, 180; Garlake, Great Zimbabwe, 118.

${ }^{47}$ Maggs, "Iron Age" in Klein, Prehistory and Paleoenvironments, 346, Phillipson, Later Prehistory 181, Garlake, Great Zimbabwe, 118; Thomas N. Huffman, "Architecture and Settlement Patterns" in ed. Joseph Vogel, Encyclopedia of Precolonial Africa: Archeology, History, Languages, Cultures and Environments (Walnut Creek: AltaMira Press, 1997), 152-53, Phillipson, Later Prehistory, 184, 181, Pikirayi, Zimbabwe Culture, 104, Guy Gardner, Mapungubwe: Ancient Bantu Civilization on the Limpopo, ed. Leo Fouché and Pieter Johannes Coertze (Pretoria: J. L. Van Schaik, 1963), 11.

${ }^{48}$ Huffman, "Patterns" in Vogel, Encyclopedia, 152.

${ }^{49}$ M. Hall Changing Past, 95.

${ }^{50}$ Rayner, Tribe and its Successors, 49.
} 
basic unit of governmental organization, were collected into larger units, their name based on the overall size of the polity in question. Non-state societies generally ended at the next level of complexity, with the sovereign essentially corresponding in authority with the European concept for 'chief.' Semi-state societies might have another level of complexity with regional or district chiefs distributed about the territory answering ultimately to a corollary to a baron, while the Mutapa or Kahmi states collected numerous powerful 'noble' or hereditary elite authorities under the leadership of a true kingship. ${ }^{51}$

The political status of the Great yaKaranga state immediately prior to its split must have been similar to Agamemnon's Argos: on the verge of uniting the whole of his ethnic brethren and striking out to leverage power on a world stage. Just as Agamemnon was able only to gather the reins for a historical moment, the siege of Troy, and true empire had to wait another few centuries for the kings of Macedon to seize their chance, the vaWene nearly reached, perhaps momentarily touched trans-Plateau nationhood, before disintegrating into two large daughter states surrounded by 'buffer' polities.

It is worth repeating that the bottom line of political organization was patriarchy, a kingship, and this study does not dispute that basic fact, it merely questions the magnitude of imbalance in social attitudes and overall power. ${ }^{52}$ The generic family-unit was organized along similar lines to a Latinized threegeneration family led by the eldest male. Differences existed however, for

\footnotetext{
${ }^{51}$ Thomas N. Huffman, "Zambezian States," in Vogel, Encyclopedia, 515-16.

52 I agree with Kent, "Invisible Gender," in Kent, Gender, 66 and Simon Hall, "A Consideration of Gender Relations on the Late Iron Age 'Sotho' Sequence of Western Highveld, South Africa," in Kent, Gender, 236.
} 
instance, in the added dimension of multiple wives and a plurality of children in elite families. It was usually, but by no means strictly, a patrilocal, patriarchal kingroup and consisted not only of the sovereign, his wives, his predecessor's wives, their sons and unmarried daughters, his uncles and brothers, their wives and children, his sons, their wives, his unmarried daughters and his patrilineal grandsons and unmarried granddaughters ad infinitum of living generations, but was also mentally constructed of the ancestral generations' memories and the collective potential of the clan for future progeny. ${ }^{53}$

At one step remove above the family was the clan, a collection of families not terribly unlike the original Roman 'tribes,' their relationship to one another traced by a shared totemic symbol. Totems essentially acted as a surname for the vaKaranga. Because each patriarchal family shared a single totem, even families that split and migrated to different villages could maintain their genetic diversity by avoiding intermarriage with their totemic cousins. ${ }^{54}$ The totem also acted as a magical and symbolic focal point around which the power of the clan could be concentrated: on the hunt; in battle; or around the campfire, where the oldest stories wove the totemic symbols of famous clans into allegories of their interactions and adventures. ${ }^{55}$

Society was made up of age-grouped units, including elders, adult males and females, children, casually divided, and the ancestors, but there is little

\footnotetext{
${ }^{53}$ Rayner, Tribe and its Successors, 50.

${ }^{54}$ Beach, Shona and Zimbabwe, 65-66.

${ }^{55}$ Ibid.; Fr. Francisco Monclaro, Account of the Journey Made by Fathers of the Company of Jesus with Francisco Barreto in the Conquest of Monomotapa in the Year 1569, in ed. \& trans. George Theal, Records of South-Eastern Africa: Collected in Various Libraries and Archive Departments in Europe III, (London: William Clowes and Sons, 1899-1903), 243; Tracey, Lion on the Path, ii.
} 
consensus on whether age grades or other initiate societies played any role in social or political organization. The unborn, not being yet individual people, were a principle to be protected, by the living and the ancestors alike. William Rayner translates the concept rudzwi, kind, or, essentially, kin, as a description of this potential future, one that must be cultivated and protected. Rudzwi was therefore the metaphysical being of the living and ancestral clan members in corporation, with the survival of the rudzwi a fundamental, in fact the most fundamental, cultural value. ${ }^{56}$ The identity of the clan was paramount: heroes were those who increased the honor or wealth of the entire clan, and the most basic responsibility of all vaKaranga adults, whether male or female, was simply reproduction. The self was subsumed in the identity of the clan. ${ }^{57}$

A young man's life labor, therefore, was devoted to earning enough cattle and other value-holding commodities to pay for his wedding. Providing for his children and, if prosperous, helping his sons to celebrate their weddings were his secondary concerns. ${ }^{58}$ One wonders about the first generation of vaKaranga society that saw a few patriarchs prosperous enough to spend lavishly for their children's weddings without imperiling their income. The clan that managed this may have been the first members of what can be called an elite 'class,' in that it was a multi-generational economic unit rather than an age based hierarchy. The whole elite clan had to be productive enough to furnish privileges to members and give its productive generations leisure to pursue other activities-commercial

\footnotetext{
${ }^{56}$ Beach, Shona and Zimbabwe, 65-66.

${ }^{57}$ Rayner, Tribe and its Successors, 50.

${ }^{58}$ Kuper, Wives for Cattle, 26.
} 
innovations like standardizing production methods, for instance. ${ }^{59}$

As this class grew and increasingly secured its position, some clans came to dominate others, both economically and militarily. In the late 11 th century CE, the clan that dominated the growing town of Bambandyanalo broke ground on a new compound nearby. Although they built their houses atop a hill, they located the public court at the base, a layout that survived into the historical period, when it was associated with developing and mature monarchical states. The interpretation that the city that would come to be called Mapungubwe is the first archaeologically visible manifestation of this monarchical statehood is borne out by finds of burial sites containing substantial markers of wealth. ${ }^{60}$

\section{Life in dzaKaranga}

According to some sources, cases of capital crime were reserved for the higher authorities of the zimbabwe, however it is possible that this included at least district heads if not regional chiefs in the larger vaKaranga societies. ${ }^{61}$ In this clannist political system dispensation of justice took place in public courts convened in the open space before the local chief's compound, in other words, inside the cattle corral, at the far point from the entrance to the settlement. Its purpose, in an environment where most litigants were members of extended family or in-laws, was more to reestablish social equilibrium through mediation

\footnotetext{
${ }^{59}$ Elizabeth Voigt, Mapungubwe: An Archaeozoological Interpretation of an Iron Age Community (Pretoria: Transvaal Museum, 1983), 79 notes that ivory remains at Mapungubwe display a consistency of manufacture suggestive of exactly this type of emergent specialized industry. ${ }^{60}$ M. Hall, Changing Past, 77.

${ }^{61}$ Beach, Shona and Zimbabwe, 93; dos Santos, Ethiopia Oriental, 1:10 in Theal, Records, VII, 201.
} 
than to rule by arbitration. ${ }^{62}$ However, if agreement could not be reached, arbitration was among the secondary solutions available to the chief.

Court days, which took place on the week-ending labor holidays, were attended with the same sort of circumstance and festivity, or likely more, than collective labor events, which will be discussed below. For those who did not have business before the court it was a draw as dramatic entertainment, and speakers were celebrated and made notorious for their performances in the same manner that history has inherited the fame of Socrates. Both criminal trials for offenses such as witchcraft and civil disputes like destruction of property were settled in these sessions. Orators for each side (not always the litigant themselves, for sometimes well known speakers would act as stand-ins for one or both plaintiffs) were encouraged by callers shouting encouragement. ${ }^{63}$ "Deco!" is the call André Fernandes recalls in a letter to the Jesuits in Portugal, and he translates it as "Well said!" or "So it is!" although surely "Preach it!" or "I heard that!" are as appropriate..$^{64}$

The proceedings, as they appeared in the 1960s to Rayner, began with opening arguments by each party. These, and all other communication that took place were relayed in brief by a lieutenant to and from the chief, who sat in judgment on a rock or stool physically higher than the assembled litigants and audience. Although everyone could hear the chief and the chief could hear each of the litigants perfectly well, this translator always served as intermediary before

\footnotetext{
${ }^{62}$ Rayner, Tribe and its Successors, 78-79.

${ }^{63}$ Rayner, Tribe and its Successors, 80-81.

${ }^{64}$ André Fernandes to the Jesuits in Portugal, 5 December, 1562, in Theal, Records, II, 147.
} 
responses could be made in either direction. ${ }^{65}$ As a point of interest to our subject, it is intriguing to wonder what role Mureche of Barwe might have played in such a scene. Would she, being very probably the dominant personality in the sovereign marriage, have left custom untouched and given Chimupore the privileges and responsibilities of magistracy? What role would she have played if she'd decided to take on any?

Each disputant would step forward as they spoke and crouch before the chief, although all dialogue would be directed at the intermediary. As he or she approached, the petitioner would clap respectfully and call out some of the chief's praise names. Their relation of the events was not a simple statement of facts but a dramatic and rhetorical performance, replete with emotional outcries and ad hominem imprecations regarding the attitude of the opposing side toward them in the past. No evidence was considered inadmissible, according to Rayner's understanding of the practices. This, he says, is because the dispute might truly be based on far deeper animosities than those that stemmed exclusively from the event in question, and as the purpose of trial was more reconciliation that adjudication, any information that served to illuminate the wider dispute between the litigants was considered useful in helping the chief come to a decision. ${ }^{66}$

After each disputant had been called forward, a succession of witnesses followed. Rayner describes these as more partisans than impartial bystanders telling the whole truth and nothing but the truth. They, in turn, would be followed by any member of the audience who felt compelled to offer his or her opinion,

\footnotetext{
${ }^{65}$ Rayner, Tribe and its Successors, 79-82.

${ }^{66}$ Rayner, Tribe and its Successors, 79-82.
} 
with the audience often grumbling along and discussing the finer points on the sidelines of the proceedings. At the end of this stage (which would last as long as there were speakers wishing to be heard) the chief would summarize the circumstances of the case as he understood them and render his judgment, which would assess a penalty from the guilty party but would also be open for feedback and input from the assembly. At bottom it was most important that submission to the judgment by both parties be voluntary, if at all possible. As a last resort, judgment would be imposed. However, as this did not relieve the tension between the parties, this was only done in the absence of any alternative, and by the 1960 s some chiefs preferred to refer such circumstances to European colonists' native commissioner courts rather than impose sentence themselves. ${ }^{67}$

At other times a party adjudged guilty might insist on his innocence, or the case might remain opaque even after extended discussion. In these circumstances, as not infrequently happened under accusations of witchcraft, recourse was made to trial by ordeal. As accusations of witchcraft were made most frequently against women in the English-record, these ordeals were a particularly important part of the legal structure in a woman's life, at least by the 19th century. The ordeals listed by J. dos Santos are lucasse, a poisonous drink which it was assumed (contrary to the European custom in which the innocent die so that the witch might be tortured) would kill the guilty while the righteous would vomit the substance up and live on, absolved; licking of a red-hot adze (the righteous are expected to be unburned); and the drinking of a bitter draught

${ }^{67}$ Rayner, Tribe and its Successors, 82. 
(the conditions under which innocence is assumed are not discussed) ${ }^{68}$ Rayner substitutes a hand in boiling water for the bitter draught, with the conditions of innocence the same as with the adze. ${ }^{69}$

Court was not the only occasion for work holidays, and it seems from the schedules found both in the Portuguese sources and the investigations by $D$. Beach that a substantial amount of time was set aside for public leisure. J. de Barros lists ten holidays out of the lunar month, more than one day in three. Essentially these fall on the first, sixth and seventh days of every ten-day week with an extra for the day of the month on which the sovereign was born. In addition, seven days (or one quarter of the month) were devoted to work-tribute, the only tribute expected of peasants in de Barros's time. A commoner might pay tribute in-kind for an audience with the mWene (or presumably with any subchief), but his labor was the only obligatory responsibility. ${ }^{70}$

De Faria e Sousa wrote that the calendar was made up of three ten day weeks with the first of the month at every new moon (the numerical discrepancy is not explained). Weekends in his time were on the fourth and fifth of each week and the most important holiday of the year, Chuavo, at the May new moon. ${ }^{71}$ Beach describes a similar calendar but notes that each sovereign chose the number of days-off individually, so that the differing numbers of work days

\footnotetext{
${ }^{68}$ dos Santos, Ethiopia Oriental, 1:11, in Theal, Records, VII, 204-05.

${ }^{69}$ Rayner, Tribe and its Successors, 95-96.

70 João de Barros, Da Asia: Dos Feitos Que os Portugueses Fizeram na Conquista e Descubrimento das Terras e Mres do Oriente, 1:10:1, in Theal, Records, VI, 271; dos Santos, Ethiopia Oriental, 1:18, in Theal, Records, 222.

${ }^{71}$ Manuel de Faria e Sousa, Asia Portugesa, 2:3:15, in Theal, Records, I, 25.
} 
between de Barros and de Faria e Sousa might be interpreted as a comment on the economies of the two periods. ${ }^{72}$ Between holidays and labor tribute there remains less than half of the month, twelve out of the twenty-eight days, devoted to one's own work, perhaps explaining the reputation vaKaranga gained among the Portuguese for indolence. It is not entirely clear, however, if both men and women (who did not have the same reputation with the Portuguese and did the most visible labor, farming) observed this same holiday-tribute schedule.

Both Early and Late Iron Age societies were agripastoralist. What set the Late Iron Age vaKaranga apart was their productivity. Their more stable agrarian regime and a convenient landmark to look for in picking a successful settlement, the high rocks of a cliff or crag (kopjes, as they're called by, in fairness, probably the first persons in the area to give such geographical features names, Dutch Africaaners) made them highly successful, and their numbers multiplied. These settlements at the edge of highland and overlooking lowland plain offered more stable cattle-keeping than flat terrain. The summer grasses of the midveld plains were supplemented by highveld grasses that were sparser but more robust in the chilly winters of inland southern Africa. ${ }^{73}$

But, while millet thrives in midland environments, spotty rainfall made it an uncertain partner with the somewhat longer-lagging cattle. Among grains, millet keeps relatively poorly, and when drought doubled the length of the crop cycle it became necessary to trade items for food with better stocked (or watered) neighbors. Lean seasons, it became clear, were an opportunity to devote

\footnotetext{
${ }^{72}$ Beach, Shona and Zimbabwe, 92.

${ }^{73}$ Pikirayi, Zimbabwe Culture, 124.
} 
otherwise wasted time into things that would be marketable during the next drought. $^{74}$ The need to supplement food stocks drove both men and women to produce secondary commodities in the time left free by their primary efforts. These goods would prove useful in trading for necessities during lean times. ${ }^{75}$

The labor regime was a collective system in which members of the community gathered to accomplish individual limited goals, organized into gangs to focus their efforts in a single area at a time. In the day-to-day labor of the year between times of peak effort like planting and harvest individual nuclear families tended their own fields, which were generally just enough to support their own subsistence or slightly more. ${ }^{76}$ In more intense labor seasons, families volunteered to help each other out as a part of the clannal system of reciprocity in which one family's fields might be planted on one day and another's done on the next day. One contributed one's efforts to planting another's field so that later they could expect to receive help in planting their own. ${ }^{77}$

As an added enticement, communal labor days were imbued with festival atmosphere. Workers were fed by the field's owner, and drinking, music and dance followed in the evening when the labor was finished. The same was true of labor-tribute days, in which the food would be provided from the chief or higher sovereign's stores. ${ }^{78}$ In a male gendered context this communal labor might

\footnotetext{
${ }_{75}^{74}$ Beach, Shona and Zimbabwe, 28-29.

${ }^{75}$ Ibid., 28-30.

${ }^{76}$ Chet S. Lancaster, The Goba of the Zambezi: Sex Roles, Economics and Change (Norman: University of Oklahoma Press, 1981), 45.

77 Ibid., 42-68.

78 Isaac Schapera and Astley John Hilary Goodwin, "Work and Wealth," in ed. Schapera, The Bantu-Speaking Tribes of South Africa (London: Routlege and Kegan Paul, 1937), 151-52.
} 
have taken the form of a combined herd driven to winter or summer pasturage by all of the men of the community.

Women were the makers of the millet beer that was drunk on these occasions, and a wife had the acknowledged right to refuse to make it, if she decided that the family's stores could not afford the burden of reduction by such a process. Although millet beer is essentially an alcoholic porridge that retains enough solid nutrition that many older middle-Zambezi Goba men farmed personal fields in order to guarantee that they could survive essentially off beer alone, according to Lancaster, the brewing process converts substantial quantities of the carbohydrates to alcohol, meaning that significantly more millet goes into the amount of beer needed to subsist without other food than goes into a day's non-alcoholic meals. ${ }^{79}$ Not surprisingly, beer was a valuable trade good, and women who devoted the extra labor and land to producing a surplus of millet could profit greatly, both in trade commodities and in the status that came with having a home where elder men, especially, came to relax. ${ }^{80}$

Elite families were far more likely to be polygamous and therefore to control the produce of more of the community's productive land. And because vaKaranga polygamy is funded by the keeping of large herds of cattle, elites are more likely to own many cattle. ${ }^{81}$ However, because the amount of capital changing hands in marriage transactions was relatively large, wealth was in a state of constant flux from generation to generation. Even the most simplistic

\footnotetext{
${ }^{79}$ Lancaster, Goba of the Zambezi, 66.

80 lbid., 50.

${ }^{81}$ Alinah Segobye, "Daughters of Cattle: The Significance of Herding in the Growth of Complex Societies in Southern Africa Between the $10^{\text {th }}$ and $15^{\text {th }}$ Centuries AD," in Kent, Gender, 228.
} 
formula for wealth could only be calculated as a function of the numbers of male and female offspring, the size of cattle herds and the value of imperishable commodities held by the household. Partly because the values of commodities remained relative to one another throughout the pan-Bantu Iron Age, this system of aggregate capital wealth was unquantifiable. And while there was certainly magnitude in the reckoning of wealth, there could be no fixed units regardless of whether they were based on a single or a basket of commodities. This was because such characteristics as beauty, mutual attraction, status of prospective partners, cultivation skill and human reproductivity all had determinative effects on value and buying power for the most valuable asset of all, wives. ${ }^{82}$

82 Michael Bourdillon, The Shona Peoples (Gwelo: Mambo Press, 1976), 52-68. 


\section{Chapter 2: Women in Precolonial Africa:}

The literature on women in Africa tends toward treating the whole continent or vast regions of it as a unit, particularly the literature dealing with periods before contact with Europe. Walter Rodney, Ifi Amadiume and Niara Sudarkasa have shown a number of ways in which themes apply broadly across much or all of the continent, and Jeff Guy and Iris Berger have found deep commonalities across savanna Bantu societies. ${ }^{83}$ While these macroscopic and theoretical findings have great value in guiding studies with a tighter focus, the greatest value to be found in surveying gender studies of past or 'indigenous' African societies is in finding a common framework through which to analyze particular African histories, in this case vaKaranga women's.

Broadly speaking, there are five main themes by which the lives or places of women in Africa are discussed in literature. By far the most common theme is women's roles in the economy. Guy is a professor of history who makes frequent use of Marxist analytical tools to examine women's role as a commodity and as an agricultural producer, Rodney's well known book How Europe Underdeveloped Africa discusses economic consequences of colonization in a section on women and Sudarkasa notes that "it was almost invariably the case that African women were conspicuous in the economic life of their societies, being involved in farming, trade or craft production." ${ }^{\prime 4}$

\footnotetext{
${ }^{83}$ Walter Rodney, How Europe Underdeveloped Africa (Washington: Howard University Press, 1982); Ifi Amadiume, Male Daughters, Female Husbands: Gender and Sex in an African Society (London: Zed Books, 1987); Niara Sudarkasa, "'The Status of Women' in Indigenous African Societies," Femenist Studies 12, no. 1, (Spring 1986): 91-103; Jeff Guy, "Gender Oppression in Southern Africa's Precapitalist Societies" in ed. Cheryl Walker, Women and Gender in Southern Africa to 1945 (Claremont: David Philip Publishers, 1990), 33-47; Iris Berger, "Women in East and Southern Africa" in eds. Iris Berger and E. Frances White, Women in Sub-Saharan Africa: Restoring Women to History (Bloomington: Indiana University Press, 1999), 5-62.

${ }^{84}$ Guy, op.cit.; Rodney, Underdeveloped Africa,115-21,226-27;Sudarkasa, "Status of Women," 91.
} 
Nancy Rose Hunt lists four different economic perspectives among a short list of papers published by the time of her 1989 historiography of African women's history; Amadiume and Berger both discuss women's ability to accumulate wealth; Margaret Strobel examines women's "productive and reproductive labor;" Jack Goody explores "the relationship between plural marriage and women's position in the economy" in Ghana, arguing that it is broadly illustrative of many societies on the continent and is in agreement in this with Nakanyike B. Musisi's findings regarding the Buganda state; and many contributors to Susan Kent's Gender in African Prehistory discuss division of labor and other economic themes visible in the archeological record. ${ }^{85}$

Also common are discussions of marriage, family and reproduction. Strobel's statement tying economic and demographic production is common, appearing also in Guy. ${ }^{86}$ Hunt discusses the status of widowhood, while Guy and Berger discuss aging. ${ }^{87}$ Guy and Berger both discuss marriage directly, as do Amadiume, Strobel, Gerald Chikozho Mazarire, Goody and Musisi. ${ }^{88}$ Kin and kinship are discussed by Gina Bujis, Rayner, Strobel and Mazarire. ${ }^{89}$

\footnotetext{
${ }^{85}$ Nancy Rose Hunt, "Placing African Women's History and Locating Gender," Social History 14, no. 3 (October 1989): 359-79; Amadiume, Male Daughters; Berger, "Women in East and Southern Africa" in Berger and White, Women in Sub-Saharan Africa; Margaret Strobel, "African Women," Signs 8, no. 1 (Autumn 1982): 109; Jack Goody, "Polygyny, Economy and the Role of Women" in ed. Jack Goody, The Character of Kinship (Cambridge: Cambridge University Press, 1974), 175; Nakanyike Musisi, "Women, 'Elite Polygyny,' and Buganda State Formation" Signs 12, no. 4, Women, Family, State and Economy in Africa (Summer 1991): 757-86; Kent, op. cit. ${ }^{86}$ Strobel, "African Women," 109; Guy, "Gender Oppression" in Walker, Women and Gender, 41. ${ }^{87}$ Hunt, "Locating Gender," 362-63; Guy, "Gender Oppression" in Walker, Women and Gender, 41-42; Berger, "Women in East and Southern Africa" in Berger and White, Women in SubSaharan Africa, 45-47.

${ }^{88}$ Guy, "Gender Oppression" in Walker, Women and Gender, 43-45; Berger, "Women in East and Southern Africa" in Berger and White, Women in Sub-Saharan Africa, 30-39; Amadiume, Male Daughters; Strobel, "African Women," 112-13; Gerald Chikozho Mazarire, "'The Politics of the Womb': Women, Politics and the Environment in Precolonial Chivi, Southern Zimbabwe, c.1840 to 1900," Zambezia XXX, no. i (2003): 35-50; Goody, "Polygyny" in Goody, Character of Kinship, 175-90; Musisi, "Elite Polygyny and Buganda State Formation."

${ }^{89}$ Gina Buijs, "Gender and Person in African Societies: The Role of Hermeneutics," Alternation, 9,
} 
Women's access to and control over space is the least commonly discussed of the major themes. Kent, in particular, discusses it, and examines many of her contributors' perspectives on space, in particular their varying attitudes to what constitutes gendered space. ${ }^{90}$ Berger, Bujis, and Mary E. Modupe Kolawole all discuss it in various ways, with Kolawole discussing women's public voice and women's representation in written and performing arts. Women's roles in religion is an important theme although it is sometimes difficult to access. Often times this is because early observers of African religions were highly prejudiced: either Muslim, Catholic or Victorian. Rodney discusses the topic, however, as do Amadiume, Strobel and Berger. ${ }^{91}$

Last, and decidedly not least, women's roles or power in politics are difficult to ignore. Mazarire and Bujis make the subject their primary focus and for Musisi they are crucial objects in the process of state formation in Buganda. ${ }^{92}$ Guy discusses women and authority; Rodney examines women's political position before European contact; Sudarkasa argues that women are more conspicuous in 'high places' in Africa than any other world region, although not in Islamic areas of the continent; Hunt discusses studies of women and law; Amadiume discusses matriarchy, titles and power and political organization and administration; Strobel discusses political roles and activity; even Kolawole finds

no. 1 (2002): 57-73; William Rayner, The Tribe and Its Successors: An Account of African Traditional Life and European Settlement in Southern Rhodesia (London: Faber and Faber, 1962), 48-53; Strobel, "African Women," 113-117; Mazarire, "The Politics of the Womb."

${ }^{90}$ Kent, "Gender and Prehistory," in Kent, Gender, 12-15.

${ }^{91}$ Rodney, Europe Underdeveloped Africa, 117; Ifi Amadiume, Reinventing Africa: Matriarchy, Religion and Culture (London: Zed Books, 1997); Strobel, "African Women," 127-28; Berger, "Women in East and Southern Africa" in Berger and White, Women in Sub-Saharan Africa, 40-42. 92 Mazarire, "The Politics of the Womb;" Buijs, "Gender and Person;" Musisi, "Elite Polygyny and Buganda State Formation," 758. 
a place to talk about the role of women's voices in political movements, although her book has decisively transitioned to colonial times by that point. ${ }^{93}$

Although there is obviously a great amount of overlap in these categories, the thesis has been organized along the lines of these five important themes in an attempt to provide a coherent structure. Because the difficulties of isolating gender information on vaKaranga society before contact with Europeans are substantial enough to begin with, attempts to build a narrative have been left behind in the previous chapter. Instead, the period from the middle fifteenth century (just prior to first contact with Europeans) through the early seventeenth century (the publication date for a number of the earliest Portuguese formal histories addressing the vaKaranga), a 'long sixteenth century,' are treated as a mostly timeless era during which Portuguese cultural pressure is incomplete enough that careful scrutiny can distinguish old from changing from new social characteristics with reasonable reliability. In introductory and conclusory sections, I've tickled the edges of the idea of a narrative of change in gender attitudes, but the real purpose of this thesis is merely to establish a 'point of origin' for vaKaranga gender studies, a women's history, narrowly defined, from which to discuss the changes brought on by contact with Europe.

\footnotetext{
${ }^{93}$ Guy, "Gender Oppression" in Walker, Women and Gender, 41; Rodney, Europe Underdeveloped Africa, 118; Sudarkasa, "Status of Women," 91-97; Hunt, "Locating Gender," 72 74; Ifi Amadiume, Reinventing Africa; Amadiume, Male Daughters; Strobel, "African Women," 124-26; Kolawole, Womanism, 43-70.
} 


\section{Chapter 3: vaKaranga Women Prior to European Contact:}

The first important contemporary scholarship on women in precolonial vaKaranga society was anthropologist William Rayner's 1962 book, The Tribe and its Successors. ${ }^{94}$ In 1980, historian David Beach contributed a major work entitled The Shona and Zimbabwe, with further analyses of women's roles. ${ }^{95}$ And the following year, anthropologist Chet Lancaster also addressed vaKaranga gender norms in The Goba of the Zambezi. ${ }^{96}$

A number of scholars returned to the topic of vaKaranga women in the 1990s. The subject got a full book treatment in Peasants, Traders and Wives, by cultural anthropologist Elizabeth Schmidt. ${ }^{97}$ The position of vaKaranga women was also the subject of book chapters by Simon Hall and by Alinah Segobye (both physical anthropologists) and by political scientist Cindy Courville. ${ }^{98}$ While other sources are included in this review, these authors have written most extensively about women's roles in traditional vaKaranga society and are drawn on most heavily here.

\footnotetext{
${ }^{94}$ William Rayner, The Tribe and Its Successors: An Account of African Traditional Life and European Settlement in Southern Rhodesia (London: Faber and Faber, 1962)

${ }^{95}$ David Beach, The Shona and Zimbabwe 900-1850: An Outline of Shona History (London: Heinemann, 1980), 96-98, for instance.

${ }^{96}$ Chet S. Lancaster, The Goba of the Zambezi: Sex Roles, Economics and Change (Norman: University of Oklahoma Press, 1981), throughout.

${ }^{97}$ Elizabeth Schmidt, Peasants, Traders and Wives: Shona Women in the History of Zimbabwe, 1870-1939 (London: Heinemann, 1992).

${ }^{98}$ Simon Hall, "A Consideration of Gender Relations in the Late Iron Age "Sotho" Sequence of the Western Highveld, South Africa" in Kent, Gender, 235-58; Alinah Segobye, "Daughters of Cattle: The Significance of Herding in the Growth of Complex Societies in Southern Africa Between the 10th and $15^{\text {th }}$ Centuries AD." in ed. Susan Kent, Gender in African Prehistory (Walnut Creek: AltaMira Press, 1998), 227-33; Cindy Courville, "Re-Examining Patriarchy as a Mode of Production: The Case of Zimbabwe" in eds. Stanlie James and Abena Busia, Theorizing Black Feminisms: The Visionary Pragmatism of Black Women (London: Routlege, 1993), 31-43.
} 


\section{Economic Roles}

The vaKaranga economy was organized on the society's clannal structure, Martin Hall's "lineage mode of production," undergirding a statewide "tributary mode of production." ${ }^{99}$ Although there was a gendered division of labor, there is debate among scholars as to if this was structural to the mode of production. As children grew, their labor was gradually segregated by gender, with boys following their fathers and uncles out to learn the business of bush-survival and girls introduced to the particular chores of farm and hearth. ${ }^{100}$ Beach asserts that "the division of labor was based mainly on the need for men to guard against shangwa (crop-failure) by going into other branches of production such as hunting or herding," while Courville asserts that women are doubly peasants, controlled both by male owners of wealth and elite concentrators of it. ${ }^{101}$

As noted in Chapter 1, scholars agree that cattle-the domain of men-were a mainstay of the evolving economy. Beach notes that archival sources claim other commercial transactions were also dominated by men, but expresses some skepticism about these sources, subject to the Swahili Muslim informants' and Portuguese Catholic ethnographers' biases. ${ }^{102}$ As we will see below, even personal experience could be misleading in this regard, because trading, as with many other gender divisions, was separated on an intramural/interregional basis.

\footnotetext{
${ }^{99}$ Martin Hall, The Changing Past: Farmers, Kings and Traders in Southern Africa, 200-1860 (Cape Town: David Philip, 1987), 65 \& 75.

${ }_{100}$ Lancaster, Goba of the Zambezi, 184-88.

${ }^{101}$ Beach, Shona and Zimbabwe, 92; Cindy Courville, "Re-Examining Patriarchy as a Mode of Production: The Case of Zimbabwe" in eds. Stanlie James and Abena Busia, Theorizing Black Feminisms: The Visionary Pragmatism of Black Women (London: Routlege, 1993), 35.

${ }_{102}$ Beach, Shona and Zimbabwe, 91-92; and Fr. João dos Santos, Ethiopia Oriental, 1:3 \& 1:12, in ed. \& trans. George Theal, Records of South-Eastern Africa: Collected in Various Libraries and Archive Departments in Europe VII, (London: William Clowes and Sons, 1899-1903), 186 \& 20708 for an example.
} 
There is consensus, however, that women were integrally involved in various aspects of economic activity, especially farming and mining. Women are responsible for cultivation of the fields, for maintaining the food supply for themselves and their children, and for their husband as necessary. ${ }^{103}$ In the dayto-day labor of the year, between times of peak effort like planting and harvest, individual nuclear families tended their own fields, which were generally just enough to support their own subsistence or slightly more. ${ }^{104}$ As Lancaster notes, women had responsibility not only for cultivation of the land, but for choosing what, when and how products were planted, harvested and processed. This responsibility for the food cycle from planting through cooking is recognized by such legal protections as the right to refuse to make beer if one's husband has not contributed labor to the field it comes from in that year. ${ }^{105}$

Their farming roles went beyond subsistence level, however. Beach notes that the same sources who claim men to have a monopoly on commerce also describe lowland women selling their rice, an important export commodity as well as a staple. ${ }^{106}$ And while Schmidt notes that the husband was responsible for the distribution of land among his wives and dependents, he would lose title to any land not under active cultivation, giving women a great deal of influence in maintaining the wealth of the family as a whole. ${ }^{107}$

Women were involved in crafts and mining as well as trade. Segobye

\footnotetext{
${ }^{103}$ Rachel MacLean, "Gendered Technologies and Gendered Activities in the Interlacustrine Early Iron Age" in Kent, Gender, 175.

${ }^{104}$ Lancaster, Goba of the Zambezi, 45.

105 Ibid., 66.

${ }^{106}$ Beach, Shona and Zimbabwe, 91.

${ }^{107}$ Schmidt, Peasants, Traders and Wives, 44.
} 
calls for more attention not only to women's role in cultivation but also in craft production. ${ }^{108}$ Lorraine Swan notes that the "greater proportion of miners were women" in vaKaranga mines, judging from the sexes of skeletons found in collapsed shafts, and is supported by Rogers Summers's and lan Phimister's findings. ${ }^{109}$ That said, it remains unclear to what degree women managed their own labor or controlled the exchange of, and value extracted from, the minerals. Scholars generally point to male ownership of the means of production, whether it was the ownership of gold mines by the sovereign, or the distribution of land by a patriarch. At the least, it is certain that vaKaranga queens had a direct role in trade. They were the trade ministers to foreign powers, they were put in charge of the most important trade routes and they were the treasurers of their clan's wealth. ${ }^{110}$ Beach suggests that the literature has perhaps exaggerated the exclusivity of men in trade, obscuring women's involvement. ${ }^{111}$

Senior wives were the keepers of the household savings (the treasurers noted above). According to Thomas Huffman, the senior wife is traditionally the only person with the right to custody of a man's possessions. ${ }^{112}$ Thus, any stockpiles of ivory tusks the family puts away, waiting for the occasional trade

\footnotetext{
${ }^{108}$ Segobye, "Daughters of Cattle," in Kent, Gender, 233.

109 Lorraine Swan, "Southeastern African Gold Mining and Trade" in ed. Joseph Vogel, Encyclopedia of Precolonial Africa: Archeology, History, Languages, Cultures and Environments (Walnut Creek: AltaMira Press, 1997), 539; Roger Summers, Ancient Mining in Rhodesia and Adjacent Areas (Salisbury: Trustees of the National Museums of Rhodesia, 1969), 21-26; Thomas N. Huffman, "Ancient Mining and Zimbabwe," Journal of the South African Institute of Mining and Metallurgy 74 (1974), 238-42; Ian Phimister, "Pre-colonial Gold Mining in Southern Zambezia: A Reassessment," African Social Research 21 (1976), 1-30.

${ }^{110}$ Antonio Bocarro, Decada Composto por Antonio Bocarro: Chronista de Sua Magestade, do Estado da India, do Feitos dos Portuguezes no Oriente Capitulo CXXIII in Theal, Records III, 358; Manuel de Faria e Sousa, Asia Portuguesa, 2:3:15, in Theal, Records I, 24; Beach, Shona of Zimbabwe, 173; and Thomas N. Huffman, "Expressive Space in the Zimbabwe Culture," Man, New Series, 19, no. 4 (Dec. 1984): 596.

${ }^{111}$ Beach, Shona and Zimbabwe, 91.

112 Huffman, "Expressive Space in the Zimbabwe Culture," 596.
} 
caravan to stop nearby and buy it all, any carved, beaten-metal or wire bracelets their daughters no longer wear, any extra tools or raw iron stock, any gold, is all kept in the care of the senior wife.

Segobye argues that women's economic role was central to the economy and to socioeconomic progress in ways that traditional scholarship has overlooked. ${ }^{113}$ This critique applies to both the early male European colonists and to more contemporary scholars. In Kent's introduction to her contributor's chapter, she notes that it was necessary for Segobye to "revise basic assumptions concerning the role of each sex in the activities that contributed to the archaeological record before analyzing site data." The latter's chapter then challenges the accepted wisdom that the process of sociocultural change was solely directed by male activities. ${ }^{114}$

\section{Marriage, Family and Reproduction}

As with many neighboring peoples, the vaKaranga were a clan-based society in which patrilocal, exogamous marriage was a central social institution. ${ }^{115}$ Beach writes that the word vaKaranga, which the Mutapa and other semi-dependent ethnic cousins used to self-identify, could be translated 'people of the wives,' i.e., the root word -karanga is reputed to mean 'wife. ${ }^{116}$

In wealthy households marriage was polygamous and according to Beach

\footnotetext{
${ }^{113}$ Alinah Segobye: "Daughters of Cattle," in Kent, Gender, 233.

${ }_{114}$ Kent, "Gender and Prehistory," in Kent, Gender, 10.

${ }^{115}$ Adam Kuper, Wives for Cattle: Bridewealth and Marriage in Southern Africa (London: Routledge \& Kegan Paul, 1982), 28.

${ }^{116}$ dos Santos, Ethiopia Oriental, 2:10 in Theal, Records, VII, 274 \& Diogo de Couto, Da Asia: Of the Deeds Which the Portuguese Performed in the Conquest and Discovery of the Lands and Seas of the East, 9:25, in Theal, Records, VI, 391; Beach, Shona and Zimbabwe, 96.
} 
adultery was common among all classes. ${ }^{117}$ Kuper provides a particularly thorough review of marriage practices, considered one of the most important studies of Bantu societies in general and regarding gender issues in particular. ${ }^{118}$ Marriage transactions involved the gift of rovora or brideprice to the father of the bride. ${ }^{119}$ At its most typical, this involved receiving cattle in exchange for his daughter's residence and work-transfer to the new-husband's clan. ${ }^{120}$ A key aim of young men was, therefore, to gather adequate property (especially cattle, iron and cloth) to exchange for a wife. Similarly, social life encouraged a girl to achieve an 'advantageous' marriage, one where she would be productive, provide adequately for her husband and where his family would thrive by her help. ${ }^{121}$

Many Bantu societies were polygamous, but only those men who amassed substantial cattle and property could manage the additional rovora for multiple wives. Hence, elite families were far more likely to be polygamous than those of other clans. ${ }^{122}$ In contrast, according to Beach, a young man from the peasant class who was unable to afford a bride-price might agree to a matrilocal arrangement until such time as his wife's value had been paid in labor to her family. ${ }^{123}$ This is an extreme example of the familial obligation that the man continues to owe his tezvara or father-in-law even after the rovora is technically paid. This obligation is so significant that Beach illustrates it with a common

\footnotetext{
${ }^{117}$ Beach, Shona and Zimbabwe, 90.

${ }_{118}^{118}$ Kuper, Wives for Cattle.

119 lbid., 14.

120 lbid., 16.

121 Ibid., 26-27.

122 dos Santos, Ethiopia Oriental, 1:15, in Theal, Records, VII, 213.

${ }^{123}$ Beach, Shona and Zimababwe, 30; 90.
} 
aphorism: "mukuwasha mukuyu, haaperi kudyiwa," which translates as 'the sonin-law is a fig tree, he never stops being eaten. ${ }^{124}$ It is also underlined by the marriage practices of vaKaranga sovereigns, who maintain power in part by taking a sister for their first wife: in this way, Beach notes, the mwene ('king,' in something very close to a direct translation) has no obligation and pays no rovora to any tezvara before himself. ${ }^{125}$

One cluster of oral histories, referring to a period immediately prior to or concurrent with the moment of first contact with Europeans, note an intriguing exception to the practice of paying a girl's father for his daughter's hand in marriage; Beach highlights a number of accounts dealing with a lineage founder who comes to power via his mother, who is said (in some of the versions) to have received dominion over the land of Barwe, a semi-state, populated by ethnic Tonga and buffering Mutapa from the Sofala coast, through a dowry from her father, the mWene Matope Nebedza of Mutapa. While it is unclear because of the disagreement in the histories whether Barwe was really Matope's to give or whether Mureche and Chimupore, the son of quiTeve, the sovereign of Teve, had still to conquer the territory themselves, the dowry of rights to conquest says the same thing for the topic at hand as the gift of the already pacified territory. ${ }^{126}$

The dominant power in a region, such as Mutapa was, simply does not give away territory to the son of a rival, particularly when we know he had two

\footnotetext{
${ }^{124}$ Beach, Shona and Zimababwe, 90.

125 Ibid., 96.

${ }^{126}$ Ibid., 163 citing Albino Manoel Pacheco, Uma Viagem de Tete ao Zumbo (Moçambique Imprensa Nacional, 1883), 23 and D.P. Abraham, "The Early Political History of the Kingdom of Mwene Mutapa, 850-1589," in Historians in Tropical Africa: Proceedings of the Leverhulme Intercollegiate History Conference (Salisbury: University College of Rhodesia and Nyasaland, 1962), 65.
} 
sons governing lesser territories to choose from as alternatives. ${ }^{127}$ The precise reasons Mureche was put in power over Barwe, which, Beach notes, straddled the best trade route from Mutapa proper to Sofala, and calls it the closest thing to a state that does not rise to that status, cannot be determined. ${ }^{128}$ However the fact of it, reinforced by the information I will discuss below, showing that Mutapa queens held full sovereignty over personal estates, attests to the normalcy of women in positions of formal authority in vaKaranga society prior to Portuguese arrival. ${ }^{129}$

In the exogamous marriages of the vaKaranga, children belonged to their father's clan (although the establishment of a new lineage, as in the example above, was a different case). ${ }^{130}$ Childbearing was of utmost importance, and a barren woman could be divorced by her husband or kept in the household as he chose; in either case her father would have to refund her brideprice or send another of his daughters. Infertile men, Rayner reports, might solicit a secret 'donation' of sperm from a brother or cousin, for the appearances of honor. ${ }^{131}$ Over the course of a few generations a family that produced a preponderance of daughters might grow their wealth in cattle and commodities by dint of the brideprices they received. ${ }^{132}$ They would thereby have sufficient wealth to contract multiple marriages per male member, presumably securing their new-

\footnotetext{
${ }^{127}$ dos Santos, Ethiopia Oriental, 2:10 in Theal, Records, VII, 273; Beach, Shona and Zimbabwe, 36, 162.

${ }_{128}$ Beach, Shona and Zimbabwe, 36, 173.

${ }^{129}$ Bocarro, Decada, in Theal, Records III, 358; de Faria e Sousa, Asia Portuguesa, 2:3:15 in Theal, Records I, 24.

${ }^{130}$ Beach, Shona and Zimbabwe, 90; João de Barros, Da Asia: Dos Feitos Que os Portugueses Fizeram na Conquista e Descubrimento das Terras e Mres do Oriente, 1:10:1, in Theal, Records, VI, 269.

${ }_{131}$ Rayner, Tribe and its Successors, 60.

${ }^{132}$ Beach, Shona and Zimbabwe, 90.
} 
won status, as each wife could be expected to multiply the potential labor available to the clan over time.

Men were responsible for most high-risk work, particularly herding and hunting (although notably not mining); wives were responsible for meal preparations and domestic routines and for cultivation of crops and some other economic activities. ${ }^{133}$ The wife was also traditionally a legitimate source of advice and support for a man in his affairs. ${ }^{134}$

Of course, women's status interacted with their economic status and with general norms about marriage. But while each woman was subordinate to her husband, she was still superior to her husband's male inferiors. ${ }^{135}$ A married, peasant woman's status, therefore, compared favorably to an unmarried, peasant man's. Unmarried women, though rare because of the polygamous practices, did have a status below even the oldest unmarried men, except that they were more likely to have a reputation as witches, giving them a dark mystique that acted as a kind of stand-in for legitimate status. ${ }^{136}$

According to Lane, another contributor to Kent's edited volume, both preinitiation children and elders form "almost 'androgynous"' groups. ${ }^{137}$ That said, it is elder women who generally help most with rearing children, and Schmidt and

\footnotetext{
${ }^{133}$ Rayner, The Tribe and its Successors, 50.

${ }^{134}$ Antonio Caiado, "Letter from Monomotapa to one of his friends in another part of that country" in Theal, Records II, 103 (while it is not clear if the Portuguese are correct in calling this woman the "Queen Mother," she is one of the Mutapa queens and is therefore either the current or the previous mWene's wife).

${ }^{135}$ Note the "Queen Mother's" presence at the first meeting between Francisco Monclaro and the mWene, in a house "to which no one is ever admitted." No other Mutapans are present. Luiz Froes, "Of the Voyage of the Father Dom Gonçalo to the Kingdom of Monomotapa and of his Happy Passing Away," in Theal, Records, II, 120.

${ }_{136}$ J. R. Crawford, Witchcraft and Sorcery in Rhodesia (Oxford: Oxford University Press, 1967), 60.

${ }^{137}$ Paul Lane, "Engendered Spaces and Bodily Practices in the Iron Age of Southern Africa," in Kent, Gender, 180-81.
} 
Fortune note their role in conveying cultural values to the children of the village by telling stories. George Fortune notes that these storytelling sessions are acknowledged as socially valuable to the extent that parents accept that they cannot pull their children away from a story for a trifling errand. ${ }^{138}$ Further, the grandmother remains the touchstone for advice to young married women, giving them a proportionate influence on the success or failure of marriage relationships. ${ }^{139}$

Inheritance practices were not based solely on birth order, but rather on the principle that "he has the best right of succession who is best fitted to govern." ${ }^{40}$ Gerald Chikozho Mazarire notes that, while women may only rarely accede to the chiefly title themselves (that, according to Schmidt), the closer relationships between what Westerners would term 'full' brothers, as opposed to genetic 'half' brothers, often dictated the succession or land distribution decisions of 19 th century chiefs in the Chivi sub-group of the Shona. ${ }^{141}$

\section{Access to, and Control Over, Space}

Women's access to space was dictated mainly by their work roles. However, a woman's status vis-à-vis other wives, and the status of their husbands vis-à-vis the social hierarchy of the village or zimbabwe played a part in the access of the individual woman.

\footnotetext{
${ }^{138}$ George Fortune, ed., Ngano, vol. 2 (Salisbury: University of Rhodesia, Department of African Languages, 1974), xi; Schmidt, Peasants, Traders and Wives, 23.

${ }_{139}^{139}$ Schmidt, Peasants, Traders and Wives, 23.

${ }^{140}$ dos Santos, Ethiopia Oriental, 1:5, in Theal, Records, VII, 191.

${ }^{141}$ Gerald Chikozho Mazarire, "'The Politics of the Womb': Women, Politics and the Environment in Precolonial Chivi, Southern Zimbabwe, c.1840 to 1900," Zambezia XXX, no. i (2003): 49;

Schmidt, Peasants, Traders and Wives, 23.
} 
Physical mobility was influenced by labor roles, which in turn were gendered: Males hunted, tended cattle, fought in battle and took part in interregional trade, all relatively high-risk activities which could, at times, take them great distances from their home territories; women ran the household, cultivated the fields, retrieved water, traded in the marketplace and gathered supplemental subsistence material in the bush, activities which gave them freedom within a bounded territory, but were restricted in comparison to vaKaranga men. ${ }^{142}$ While this inter-regional/intra-regional distinction is likely an accurate picture of general circumstances, women did, at times, take part in the hunt, go on campaigns with the army and were at least represented in trade and diplomatic missions to foreign powers, although it is unclear the gender of these representatives. ${ }^{143}$

The normal settlement, according to Huffman's CCP framework, was laid out to offer protection and defense of men's cattle, the possessions that marked male power. The household, which was the woman's domain, was on the outer ring of the homestead and in this sense more vulnerable to raid. ${ }^{144}$ This superficial expression of masculine supremacy is consistent with other exterior signifiers, like the oft-cited aphorism that "a man being the male should have horns," which many take as a suggestion that human males should physically dominate their mates the way gender-dichotomous prey animals presumably do, however delving deeper offers a modified picture. ${ }^{145}$

\footnotetext{
${ }^{142}$ Lancaster, Goba of the Zambezi, 43-46.

${ }^{143}$ de Faria e Sousa, Asia Portuguesa, 2:3:15 \& 16, in Theal, Records I, 24 \& 27; de Couto, Da Asia, Capitulo XXIII in Theal, Records VI, 376; dos Santos, Ethiopia Oriental 2:6, in Theal, Records VII, 263; Bocarro, Decada, Capitulo CXXIII, in Theal, Records III, 358.

${ }^{144}$ Thomas N. Huffman, "Archaeology and Ethnohistory of the African Iron Age," Annual Review of Anthropology, vol. 11 (1982): 140-41.

${ }^{145}$ dos Santos, Ethiopia Oriental, 1:12, in Theal, Records, VII, 207.
} 
Paul Lane explains that the location of a household was itself a reflection of status. ${ }^{146}$ The senior wife of a chief was apportioned the second or even the first spot in the spacial organization, directly opposite the settlement entrance or immediately beside that space if the residence of the senior male were in the first spot. The third rank of social prestige was beside the first rank on the other arc of the circle, and the locations proceeded less desirable, alternating sides from left to right. What is important to note is that although this spacial metaphysics designates a left side/right side pole for femininity, women were not restricted to the left side of the compound: their status took precedence over their gender in the position of their home. ${ }^{147}$

Lane compares Iron Age Southern African societies to the gender regime described by Leach among the Mande of Sierra Leone, saying that senior wives have "a more active role in household decision making and the organization of farm labor" and are "much more closely related with upland farm plots" than junior cowives, who are more usually associated with household space. ${ }^{148}$ Archaeological evidence of women's and children's remains in mines suggests that they were also actively involved in the mining of gold and copper. ${ }^{149}$

\footnotetext{
${ }_{146}^{146}$ Lane, "Engendered Spaces," in Kent, Gender, 183.

${ }_{147}^{147}$ Huffman, "Architecture and Settlement Patterns," in Vogel, Encyclopedia, 152-53.

${ }^{148}$ Melissa Leach, "Women's Crops in Women's Spaces: Gender Relations in Mende Rice Farming," in ed. Elizabeth Croll and David Parkin, Bush Base: Forest Farm (London: Routledge, Chapman \& Hall, Inc., 1992), 84 cited in Lane, "Engendered Spaces," in Kent, Gender, 180. ${ }_{149}$ Swan, "Gold Mining and Trade" in Vogel, Encyclopedia, 539; Summers, Ancient Mining in Rhodesia, 21-26; Huffman, "Ancient Mining and Zimbabwe," 238-42; Phimister, "Pre-colonial Gold Mining," $1-30$.
} 


\section{Women in Religious Life}

Evidence about the role of women in religious life is drawn primarily by extrapolating from contemporary practices that are viewed as likely having survived from precolonial spiritual life. Overall, they suggest that, while the highest religious positions are often the domain of men, religion is a sphere in which women regularly held authority. In ethnographic research from the mid1980s, Schmidt reported that, although she interprets them as "anomalies in an extremely patriarchal society," women did hold certain positions of respect and power, particularly in religious life. ${ }^{150}$ For example, because women gathered plants and herbs, they tended to be knowledgeable about their pharmacological properties, which gave them opportunities to become healers. As Schmidt reports, women also had roles as visionaries:

Women, as well as men, attained the highly prestigious position of spirit medium (svikiro) ... The gift of divining and healing was commonly attributed to a person's communion with alien spirits (mashave), which, as noted above, were frequently associated with outsider women ... The vocation of n'anga [diviner] was one of high status and could result in considerable material rewards. ${ }^{151}$

Similarly, Pikirayi, notes that "in many present-day traditional societies the chief's sister may also be the rainmaker," arguing that this practice can likely be extrapolated to the past reliably. ${ }^{152}$ As Pikirayi is even more averse than most scholars to supposing what he describes as unfairly facile "ethnographic

\footnotetext{
${ }^{150}$ Schmidt, Peasants, Traders and Wives, 29.

151 lbid., 24.

152 Pikirayi, Zimbabwe Culture, 105-06.
} 
analogies," his willingness to do so in this instance is telling. ${ }^{153}$ This religious authority was not limited to the spiritual or ceremonial circumstances, either. Schmidt notes that spirit mediums, famously the female mediums primarily responsible for mobilizing the 'First Chimurenga,' an uprising against the imposition of a hut tax in the first decade of British occupation of the Zimbabwe plateau, 1896-97, often had political influence with the male chiefs who held temporal power. ${ }^{154}$

There is some confusion here in that Schmidt asserts that an important indicator of women's "extremely" subservient position was that, while women were not-uncommonly svikiro or 'lineage spirit' mediums, "it was extremely unusual for women to be acknowledged as mhondoro" or 'royal' mediums. However, in referring to the Nehanda spirit who led the revolt (a characterization Schmidt calls exaggerated, but which is supported by the fact that the execution of the medium effectively ended the revolt) Schmidt does not hesitate to refer to this female medium, who channels the mudzimu (spirit) of a female royal ancestor, as mhondoro. ${ }^{155}$ Other sources agree the Nehanda is mhondoro. ${ }^{156}$ Malevolent spirits, in contrast to good mashave, are often feminized. The vaKaranga understand possession (as opposed to channeling, done by mediums in misnamed possession trances, a distinction between temporary and permanent or semi-permanent communion) to be both naturally occurring and solicited by would-be magic users. This is true of both 'diviners' and 'witches,'

\footnotetext{
${ }^{153}$ Pikirayi, Zimbabwe Culture, 94.

${ }^{154}$ Schmidt, Peasants, Traders and Wives, 28.

155 Ibid., 24, 26-28.

${ }^{156}$ Beach, Shona and Zimbabwe, 104 \& 314 for instance.
} 
the English words best translating the terms for sanctioned and unsanctioned, good and evil users. Involuntary possession is considered by far the more powerful form, and more so if the possessed consciously accepts their possession and enthusiastically pursues the study of magic. With witches, both types of possession involve the witch's body, mind, actions and motivations being primarily driven by the spirit. ${ }^{157}$

Usually witches are women, and usually the spirits that possess them are believed to be one of the woman's own ancestors, usually female as well. ${ }^{158}$ Diviners, by contrast, are more often (though not as exclusively) men, and are understood to be controlled by the living being, who uses and is magnified by the spirit, rather than controlled by it. ${ }^{159}$

While this gendered distribution is well attested in the professional ethnography of the 20th century, however, it is entirely absent from the primary sources. In fact, the only explicit reference to gender regarding a magic user in the primary material (aside from the "chief-wizard" of a particular mWene we Mutapa's court, whose position is referred to with the masculine noun in Portuguese) is a powerful mage who accompanies the main force of the Mongaze army to their first full scale engagement with the Portuguese. While the witch or diviner status of this 'mage' (a generalized term, derived from popular fiction, for any manipulator of supernatural forces) is only implicit in the fact that the Mongazes exude overconfidence in the face of the fewer than one

\footnotetext{
${ }^{157}$ Michael Gelfand, The African Witch: With Particular Reference to Witchcraft Beliefs and Practice Among the Shona of Rhodesia (Edinburgh: E \& S Livingstone, 1967), 23-46.

158 lbid., 25.

${ }^{159}$ Rayner, Tribe and its Successors, 86, 93.
} 
thousand European and allied African soldiers of the invasion force, this can do no more than suggest that they lack sufficient motivation to violate strong taboo in seeking assistance from a witch. Three sources describe the mage as female and one, less convincingly, as male. ${ }^{160}$

Opinions vary on whether vaKaranga culture included a rite of passage, and although there is nothing explicitly religious about the rites themselves, if they existed at all, Eugenia Herbert has postulated a 'transformational paradigm' in some African societies covering irreversible activities that include an ambiguous period during which the outcome may be in some doubt and which often require manipulation of metaphysical forces, and she includes the transformation of children to adults in passage rites under this umbrella. ${ }^{161}$ For social structures that fit this paradigm and do not intuitively fit in other sections of the study, Herbert's classification has been used as a model. During the vaKaranga rite, as Huffman depicts it, intensive social schooling takes place and both boys and girls are indoctrinated with the society's sexual mores. ${ }^{162}$ vaKaranga children, of either sex, are not circumcised according to Fr. Dom Gonçalo Silveira (though Huffman disagrees based on ethnographic comparison to the present-day baVenda), but the rite of passage institution is essential because it is the only formal instruction broadcast to society at large. ${ }^{163}$

\footnotetext{
${ }^{160}$ Faria e Sousa, Asia Portuguesa, 2:3:16, in Theal, Records I, 27, de Couto, Da Asia, Capitulo XXIII in Theal, Records VI, 376, dos Santos, Ethiopia Oriental 2:6, in Theal, Records VII, 263, Fr. Francisco Monclaro, Account of the Journey Made by Fathers of the Company of Jesus with Francisco Barreto in the Conquest of Monomotapa in the Year 1569, in Theal, Records, III, 243.

${ }^{161}$ Eugenia Herbert, Iron, Gender and Power: Rituals of Transformation in African Societies (Bloomington: Indiana University Press, 1993), 221.

162 Thomas N. Huffman, "Where You Are the Girls Gather to Play: The Great Enclosure at Great Zimbabwe" in ed. Martin Hall, et al., Frontiers: Southern African Archeology Today (Oxford: British Archeological Reports, 1984).

${ }^{163}$ Fr. Dom Gonçalo Silveira, Letter to the Jesuits of the College at Goa, in Theal, Records, II, 94.
} 


\section{Women in Political Life}

At the apex of political authority in vaKaranga life was nearly always a

man. Schmidt asserts that males "made the decisions that governed public life, regulating relations and settling disputes." ${ }^{164}$ While her study found that women occasionally did ascend to the supreme chieftainship of a polity, she describes these women as "anomalies," going on to say they had "attained positions that conferred status and prestige usually reserved for men."165

Lancaster, however, concludes that the power of women in vaKaranga societies was at some point in the past formally recognized and substantial. ${ }^{166}$ The numerous senior Mutapa queens held substantial estates as personal fiefs, granting them authority at least equivalent to the male district governors and high level advisors of the court, including power to pass capital sentence. ${ }^{167}$ Hugh Stayt, discussed at length in Gina Bujis's "Gender and Person in African Societies: The Role of Hermeneutics," writes that "even men...to whom all other women kneel, must kneel to the makhadzi," the baVenda sovereign's paternal aunt, his predecessor's sister. ${ }^{168}$

Senior queens were often an mWene's close female relatives, a breaking of a strong taboo against incest that Van Warmelo and Phophi theorized is a relic of the proto-Niger-Congo idea of 'sacred kingship' otherwise lost among Bantu. ${ }^{169}$

\footnotetext{
${ }^{164}$ Schmidt, Peasants, Traders and Wives, 14.

165 Ibid., 29.

${ }^{166}$ Lancaster, Goba of Zambezi, 10.

${ }^{167}$ Faria e Sousa, Asia Portuguesa, 2:3:15, in Theal, Records I, 24; Bocarro, Decadas, Capitulo CXXIII, in Theal, Records, III, 358.

${ }^{168}$ Gina Buijs, "Gender and Person in African Societies: The Role of Hermeneutics," Alternation, 9, no. 1 (2002): 59 on Hugh Stayt, "Gender and Personhood," in The BaVenda (Oxford: Oxford University Press, 1931), 196-97.

${ }^{169}$ Nicolaas J. Van Warmelo and W. M. D. Phophi, Venda Law (Pretoria: Government Printer,
} 
Beach, while denying that Shona sovereigns are revered as sacred kings, describes a Mutapa philosophy of kingship. He notes that a Mutapan ruler's sister, an Nzou-Samanyanga heiress, had "certain political uses" as a senior wife, and that they were "powerful personalities."170

vaKaranga senior queens appear to have had an administrative role over dependent labor for the royal clan: Bujis notes older wives' roles as menial workers and Bocarro, that each senior queen had numerous junior queens in residence on the royal estates she controlled: "and all obey the chief wives in whose house they live, and wait upon them as their servants." ${ }^{171}$ As the successor king took all of his predecessor's wives as his own, "only excepting his own mother," these senior queens would be in charge of rather large cadres of gold-mining and millet- or rice-cultivating dependent laborers each. ${ }^{172}$ It seems likely that the "thousands" figure written by a number of sources was an exaggeration of the number witnessed by the Portuguese source or their informant themselves, however it may have been an accurate estimate to account for the numbers unseen on estates not toured by the informants. ${ }^{173}$

Beach asserts that the philosophy of kingship is to marry incestuously in order to keep these "political uses" operating: after all, land that is not in constant cultivation reverts to the market, for fair distribution by the sovereign, and a

\footnotetext{
1948), 37.

${ }_{171}^{170}$ Beach, Shona and Zimbabwe, 96, 102-03.

171 Buijs, "Gender and Person," 60 in Stayt, BaVenda, 201; Bocarro, Decada, Capitulo CXXIII in Theal, Records III, 358.

${ }_{172}^{172}$ dos Santos, Ethiopia Oriental, 1:5, in Theal, Records VII, 191.

${ }^{173}$ Monclaro, Account, in Theal, Records III, 229; de Barros, Da Asia, 1:10:1 in Theal, Records VI, 272; and dos Santos, Ethiopia Oriental, 1:5 in Theal, Records VII, 191, in which quiTeve, with 1/9 to $2 / 9$ the number of senior queens as the Mutapa might be estimated to have a similar ratio of total wives, $~ 450-1,200$.
} 
woman takes her labor to her husband's clan. ${ }^{174}$ Beach also notes that the first wife of an mWene, the most likely to have been a sister by established tradition, was not always the most influential because she was likely married to him before his ascension. Later wives, married in order to cement alliances, were often more important than the earlier ones, whether or not they were the mWene's sisters or aunts. ${ }^{175}$ This flips Schmidt's notion that the relationship to their husband is of special relevance to their status in the hierarchy of wives on its head in that it shows that these women bring the status of their family connections with them into their new position. ${ }^{176}$

While Schmidt and others might respond that this only shows that the women's statuses are dependent on their connections to powerful men, this argument would be both anachronistic and inaccurate. ${ }^{177}$ In a clan-organized political system (as, in fact, in an aristocratic one), all status is founded on the holder's connections to their blood relatives, and what is more, this mechanism operates universally across gender. Meanwhile, it is the family's overall status that establishes this baseline, by no means the same thing as the connections to males with status. ${ }^{178}$

\footnotetext{
${ }^{174}$ Beach, Shona and Zimbabwe, 96.

175 Ibid.

${ }^{176}$ Schmidt, Peasants, Traders and Wives, 16.

177 Ibid., 29.

${ }^{178}$ While in Portuguese aristocratic society, for example, all positions of authority were held by males, making the sum of a person's status effectively the sum of the authority of male connections, this is not true at all of vaKaranga society, where the member of an elite clan with the highest formal position might easily be a senior queen of the mWene we Mutapa. Her status, precisely like that of her father or brother, would be calculated as a summation of the power of their clan as a whole (rather than just the patriarch, whose own status is built on the size and wealth of the entire clan: imagine, for instance, that the patriarch's son is a mukomohasha, a general, and a niece is a famous n'anga) plus the power of the queen's office. In other words, not only does the male power confer added status on the queen's 'majesty,' her power acts in the opposite direction, adding political power to their status, a fact that is evident because marriages
} 
Another example of formal female authority is the makhadzi, the sister of a late chief among the baVenda. Citing Stayt, Bujis writes:

The chief is supposed to consult [the makhadzi] and follow her judgment on all matters concerned with the affairs of his people. She lives at the chief's capital, with her husband and children living elsewhere. She receives a percentage of all taxes given to the chief, who must grant all her reasonable requests. She is treated with most of the respect and formality accorded to the chief.

Even men, Stayt says, to whom all other women kneel, must kneel to the makhadzi. Her food is prepared, like that of the chief, by one of his wives, and presented to her with the same ceremony as it is given to him. All this respect, notes Stayt, is the outward and visible sign of the real power which she wields in the state. In addition, her home is a sanctuary for criminals and murderers, whom she may reprieve and her consent is needed before war may be waged. In all these matters her judgment takes precedence over that of the chief and he is bound to submit to her decisions. ${ }^{179}$

The baVenda are descended from the Khami-state branch of the vaKaranga, hinting at broad continuity in the positions of women across both states of the first contact period. The mWene we Mutapa's mother held a very similar position to the makhadzi of the baVenda. ${ }^{180}$ For example, when Swahili merchants made exaggerated claims against Father Gonçalo Silveira the mWene consulted his mother on how to deal with the perceived betrayal. ${ }^{181}$ In similar fashion, the sister-wives of the mWene are similar to the baVenda sovereign's own sister, the khadzi

The mWene's senior wives, too, had status and privileges akin to those described by Stayt and Bujis, who characterize sovereignty as a pie, held by the

function as reciprocal guarantors of political alliances, with real obligations on both sides (Beach, Shona and Zimbabwe, 96).

${ }_{179}$ Stayt, BaVenda, 195-96 from Buijs, "Gender and Person," 60.

180 Bujis, "Gender and Person," 60.

${ }^{181}$ Caiado, Letter from Monomotapa, Theal, Records II, 103. 
clan's chief, the ultimate sovereign, but with a four 'thumb' steering committee made up of the makhadzi, khadzi, the chosen brother of the former sovereign (the khotsimunene) and the chosen brother of the current one (the ndumi). In this way, the sovereign's attention is kept on what is best for the entire royal clan, rather than himself. ${ }^{182}$

Among the more compelling accounts of powerful elite women in the literature on precolonial vaKaranga culture is that of the Mutapa Princess Mureche, later Queen of Barwe. Mureche, as I have noted, was made the puppet ruler of Barwe in preference to at least two brothers, whose territories, also given to them by mWene Matope Nebedza, were less strategically, economically or militarily important to his power, according to Beach. ${ }^{183}$ Castille, ruled by a woman at almost the same time, if not precisely the same, and a far more institutionalized state political system, did not accept a woman sovereign without open dissent. ${ }^{184}$ Yet Mureche's sovereignty over a non-vaKaranga, the baTonga, not only survived her, the lineage she established under the name of her son Makombe remained the elite clan in Barwe until at least Beach's time, although they assimilated to the local language. ${ }^{185}$

Most women were not in the most elite circle, of course, let alone the ultimate sovereign (even a puppet one) of an entire semi-state. These women still held certain forms of political power, however. For example, although the children of the senior wife usually did not inherit the Mutapa 'throne,' their mother

\footnotetext{
182 Bujis, "Gender and Person," 59-60 using Stayt, BaVenda, 195.

${ }^{183}$ Beach, Shona and Zimbabwe, 36; 173.

${ }^{184}$ Barbara F. Weissberger, Isabella Rules: Constructing Queenship, Wielding Power (Minneapolis: University of Minnesota Press, 2004).

${ }^{185}$ Beach, Shona and Zimbabwe, 163.
} 
was an influential voice in the succession of the subordinate wives' sons, partly by dint of her relative neutrality. ${ }^{186}$ Even in non-elite households as recently as the 1990s, Huffman writes, the dead head-of-household's eldest sister was the executor of her brother's estate. ${ }^{187}$

Female nouns were used to signify positions of respect and power in the Mutapa state, as well. Beach points to Father Francisco Monclaro's and Friar João dos Santos's anecdotes, in which the mWene uses the terms 'wife' and 'great wife' as "an honour and as a sign of affection."188 "Indeed," writes dos Santos, "the Kaffirs have a great veneration for the Portuguese who have the title of the king's [mWene's] wife."189 Indeed, this title, formally bestowed by the mWene, entitled recipients to all of the respect and the privileges due to a queen. In addition, Sono, the title of the army chief, translated as 'woman,' and we have already noted that the root word -karanga translates as 'wife..$^{190}$

Finally, note Lancaster's assertion that the vaKaranga's adherence to patriarchal norms was not set in stone. He documents how vaKaranga who migrated across the Middle Zambezi became the Middle-Zambezi Goba-a matriarchal society with female chiefs-partly through marriages to local women from matriarchal societies, common north of the river. They adopted these norms favoring female power without sign of social upheaval on their account. ${ }^{191}$

\footnotetext{
${ }^{186}$ Beach, Shona and Zimbabwe,96.

187 Thomas N. Huffman, Snakes and Crocodiles: Power and Symbolism in Ancient Zimbabwe (Johannesburg: Wits University Press, 1996), 93.

${ }_{188}$ Monclaro, Account in Theal, Records III, 251.

189 dos Santos, Ethiopia Oriental, 1:20 in Theal, Records VII, 225.

190 Ibid. 1:20, 225 and 2:9, 271; Damião de Goes, Chronica do Felicissimo Rei Dom Emanuel da Gloriosa Memoria (Chronicle of King Emanuel), 2:10, in Theal, Records, III, 130 and Beach, Shona and Zimbabwe, 96; 106.

${ }^{191}$ Lancaster, Goba of the Zambezi. While the Goba themselves are not directly representative of
} 


\section{Chapter 4: Primary Literature Review and Methodology:}

There is little, if anything, in the way of new archival source material to be found regarding the vaKaranga prior to the arrival of the British in the region in 1890. Whatever little tidbits dealing with interior peoples, places or environments that are missed in George Theal's nine volume compendium of 'important' material collected and translated from the archives of Portuguese, Jesuit and other Catholic Church authorities seem to have been swept up by Antonio da Silva Rego's indiscriminate seven volume collection of all mentions of South-East Africa, whether their value was readily apparent or not. ${ }^{192}$ The vast majority of the latter set is administrative documents that tell us surprisingly much about the activities of the Portuguese themselves, but disappointingly little about peoples of the interior, and even less about gender among those peoples. While there is one useful piece of gender information in da Silva Rego's Documentos, it is primarily Theal's Records of South Eastern Africa which have proved useful for this study.

Activities in the field, like collections of core words or oral traditions from groups and sub-groups, show more promise of shedding truly original light on previously unilluminated corners in the semi-darkness of vaKaranga history. Any

mainstream vaKaranga culture, Lancaster makes a strong case that their matriarchal society is not an anomalous derivation but a natural variation from commonly occurring social mutations in which vaKaranga women came into power by socially sanctioned methods (p.10). This, of course, stands in stark contrast to Schmidt's argument that Shona women in power, even prior to British occupation were "anomalies in an extremely patriarchal society." (p. 29)

192 George Theal, ed. \& trans., Records of South-Eastern Africa: Collected in Various Libraries and Archive Departments in Europe 9 Vols. (London: William Clowes and Sons, 1899-1903); Antonio da Silva Rego, ed., Documentos Sobre os Portugueses em Moçambique e na África Central, trans. T. W. Baxter, 7 Vols. (Lisbon: National Archives of Rhodesia and Nyasaland, 1962). 
hopes of finding material of this nature in the Historical Archives of Moçambique, however, were frustrated by the relative youth and lack of funding of that facility or perhaps simply by the author's pidgin Italian/Spanish/Portuguese, which probably resulted in miscommunication despite his best efforts. Copies of many of the original documents in Theal's work are to be found there in microfilm form, however, and the opportunity to observe the greatly varying calligraphy skills of the Latin Catholic priests, the ships' captains, the third sons of Castilian noblemen looking for adventure and the convicted felons who populated the colonizing workforce, as well as the signature of King Manuel himself held its own sort of value.

Lacking funding, it was not practical to attempt field studies, however enlightening the experience might have been, and this investigation was perforce limited to in-depth readings and close textual analyses of the materials already available in print. This exercise, however, was not as redundant as might be feared, particularly as regards the sub-topic it eventually settled on for closer analysis.

While some concerted efforts have been made, particularly in the last thirty years, to describe and analyze vaKaranga gender, and much has even been done to focus on authentic or 'pre-colonial' vaKaranga attitudes toward gender, weaknesses, some minor but others quite glaring, are evident.

First and foremost, those who have attempted to isolate gender in precolonial Bantu societies have generally ignored historical sources: only Rayner, Beach, and Lancaster drew on the extensive archives from the early Portuguese 
visitors, and among them Beach pays little attention to gender, Lancaster writes only a synopsis of pre-colonial society and Rayner puts much the greater focus on British records. ${ }^{193}$ While the more recent scholars, including Schmidt and Courville, reference the archives of the British colonists extensively, these were generally collected by administrators or courts, and even those which reference the past (usually by means of reminiscences, accounts of grievances that started before the Pioneer Column's arrival in 1890 , or other personal accounts that extend only as far back as living memory) refer to the period prior to British involvement but long after Portuguese influence began. ${ }^{194}$

Secondly, we have noted above how many scholars are skeptical of the reliability of the oral traditions. Inconveniently, the most accepted limit of reliability is about 1500 , the limit at which they can be compared to Portuguese sources. ${ }^{195}$ Sadly, no one has yet come up with a method to test the reliability of oral sources independent of written corroboration, nor is there a systematic characterization of the rate at which traditions maintain consistency over time.

Furthermore, oral traditions are even more single-minded political histories than early twentieth century written historiography was, essentially being royal lineages with some details of the politics that caused or resolved disputes and perhaps an origin myth for the founders. The frequency with which women

\footnotetext{
${ }^{193}$ David Beach, The Shona and Zimbabwe 900-1850: An Outline of Shona History (London: Heinemann, 1980); William Rayner, The Tribe and Its Successors: An Account of African Traditional Life and European Settlement in Southern Rhodesia (London: Faber and Faber, 1962); Chet S. Lancaster, The Goba of the Zambezi: Sex Roles, Economics and Change (Norman: University of Oklahoma Press, 1981).

${ }^{194}$ Elizabeth Schmidt, Peasants, Traders and Wives: Shona Women in the History of Zimbabwe, 1870-1939 (London: Heinemann, 1992); Cindy Courville, "Re-Examining Patriarchy as a Mode of Production: The Case of Zimbabwe" in eds. Stanlie James and Abena Busia, Theorizing Black Feminisms: The Visionary Pragmatism of Black Women (London: Routlege, 1993)

${ }^{195}$ Beach, Shona and Zimbabwe, 59-62.
} 
appear in these traditions is commensurate with their numbers as the ultimate sovereigns in vaKaranga society, except in the origin myths, in which, Schmidt notes, they frequently appear as catalysts, vessels or even actors in the events that give birth to lineages. ${ }^{196}$ On at least one occasion a woman is the founder of the lineage, although it is Mureche of Barwe's son, Makombe who gives his name to the dynasty, appropriate for a patrilineal descent-reckoning society. ${ }^{197}$

The final problem is that there is a tendency to apply the term 'pre-colonial' to the entire period prior to the first English-language records on the region. ${ }^{198}$ Schmidt, for instance, explicitly equates the nineteenth century to the time "prior to the European occupation." 199 While this Anglocentrism is not uncommon in any region of African historiography, excepting perhaps where it is substituted by Francocentrism, the fact of the matter is that there are few places anywhere on the continent that did not see at least two if not all three of the 'C's' of colonialism ('Commerce,' 'Culture' and 'Christianity') long before the so called 'Scramble.'

In the case of the vaKaranga, the rules laid out in the Berlin Conference may have been a primary cause of this continuing shortsightedness. The only truly new feature of post-Berlin colonization lay in the 'Principle of Effectivity,' which required European powers to occupy territories with local acquiescence, flags flying and standing administrative and security forces throughout the territory claimed in order to be recognized by other European powers. ${ }^{200}$ While

\footnotetext{
${ }^{196}$ Schmidt, Peasants, Traders and Wives, 26.

197 Beach, Shona and Zimbabwe, 163.

198 Lancaster, Goba of the Zambezi, 170, 153-55; Schmidt, Peasants, Traders and Wives, 44.

199 Schmidt, Peasants, Traders and Wives, 17.

200 General Act of the Conference of Berlin Concerning the Congo The American Journal of International Law, Vol. 3, No. 1, Supplement: Official Documents (Jan., 1909), 24.
} 
Portuguese manpower throughout the Mutapa state had once been sufficient to fulfill this requirement, and perhaps even to expand contact to the Khami state had the need been present in the seventeenth or early eighteenth centuries, by 1885 her power had waned and a concerted effort was underway to reassert her presence on the Zimbabwe Plateau in anticipation of the agreement on effectivity. ${ }^{201}$

When the British Government issued its 1890 ultimatum to the King of Portugal however, it became a matter of national interest to deny the presence of Portuguese then or in the past in however much territory was possible, for the purpose of appearing not to break the Treaty of Berlin. ${ }^{202}$ Although scholars have been aware of some problems caused by this willful blindness (the confusion caused by British insistence that the Portuguese-mapped Mount Afur was not the heights they renamed Mount Darwin is the best known), somehow this awareness has not translated to more thorough acknowledgement of the Portuguese presence and influence on the plateau before British conquest. ${ }^{203}$

The fact of the matter is that Portuguese colonies of several hundred settlers each, served by wood- and stone-built churches and operating trade fairs were built at three separate locations many miles south of the Zambezi and were inhabited for hundreds of years. ${ }^{204}$ That the colonies eventually declined and were lost even to cartographers by the 1880s must not be allowed to obscure the

${ }^{201}$ Charles Nowell, The Rose-Colored Map: Portugal's Attempt to Build an African Empire from the Atlantic to the Indian Ocean (Lisbon: Junta de Investigações Científicas do Ultramar, 1982).

202 João Ferreira Duarte, "The Politics of Non-Translation: A Case Study in Anglo-Portuguese Relations," TTR : traduction, terminologie, rédaction 13, no. 1 (2000): 95-112.

${ }^{203}$ Innocent Pikirayi, The Archaeological Identity of the Mutapa State: Towards an Historical Archaeology of Northern Zimbabwe (Uppsala: Societas Archaeologica Upsaliensis, 1993), 43. ${ }^{204}$ Innocent Pikirayi, The Zimbabwe Culture: Origins and Decline of Southern Zambezian States (Walnut Creek: AltaMira Press, 2001), 175-81. 
fact that Portuguese culture, religion and trade dominated the Zambezi-Limpopo region from the beginning of the sixteenth century at least until 1700, when her overseas empire began to dissolve in earnest. This thesis incorporates the historical sources into the historiography of gender in vaKaranga society through close, textual analysis, comparison and corroboration with interdisciplinary sources, and by my having enough Latin grammar to know when the Portuguese version of the translated documents might hold another tidbit of information obscured by the English. Because of the lack of clarity burdening the term 'precolonial,' however, I have avoided its use wherever possible.

This thesis aims to illuminate 'authentic' vaKaranga society, what is sometimes called 'indigenous' society. To do this, it is necessary to look beyond the earliest influence of Europeans in the region. This is not easy information to find. The principle that observing something changes it has different names in different scientific disciplines, from the 'uncertainty principle' to 'reactivity.' In social science it is called the 'Hawthorne effect' after social experiments conducted at the Hawthorne Works, an electronics equipment factory that saw its findings on productivity in different lighting environments evaporating as soon as the social scientists wrapped up their study. 205

The fact that the first written information about vaKaranga society was set down by outside observers is only the smallest of the problems faced in getting at this truly authentic understanding of pre-colonial vaKaranga gender. The primary sources themselves are universally Iberian Catholics writing in a period that

\footnotetext{
205 John French, "Field Experiments: Changing Group Productivity" in ed. James Miller, Experiments in Social Process: A Symposium on Social Psychology (New York: McGraw-Hill, 1950), 82.
} 
stretches from the height of the Reconquista through the Counter-Reformation. Even the laypeople exhibit such a depth of faith, such an assurance in the absolute truth of the doctrine of the Church that the simple fact of muKaranga's belief in a supreme metaphysical being is taken as an inaccurate belief in the Christian god, further proof that there is one and only one deity. ${ }^{206}$ For this reason, almost any statement made by a source from the Portuguese tradition regarding those issues that the Catholic church considered its proprietary domain: social issues, particularly gender issues; sexuality; marriage; spirituality; religion; worship; ceremony; etc. must all be questioned, massaged for the believable details and sifted for the bias.

The most important of the primary sources is probably João dos Santos's Ethiopia Oriental, despite his rather overt distain for the vaKaranga themselves. His humanist theoretical framework drove him to document the region so exhaustively that despite his frequent equation of the human and other fauna of the region, the level of detail in his description of indigenous cultures is quite a bit deeper than any other source's analysis. Manuel de Faria e Sousa and Antonio Bocarro's information on the court of the mWene we Mutapa is among the best political history available for any society in the physical and chronological area, with real names, not just of vaWene, but of queens, councilors and other highranking personalities. Father Francisco Monclaro is also a complicated source, whose self-serving revisions of events narrated by multiple other sources and evident relish in recounting the most scandalous and salacious anecdotes he can

\footnotetext{
${ }^{206}$ Monclaro, Account in Theal, Records III, (London: William Clowes and Sons, 1899-1903), 230, for instance, also see the petition to the king from the residents of Moçambique, asking for a fully invested bishop so they could have their sons ordained, in Theal, Records V, 199-201.
} 
find undermine an otherwise informative and detailed account of vaKaranga at war. João de Barros's Da Asia, while drawn along similar humanist lines to dos Santos's Ethiopia Oriental, takes a rather broader subject, and shows substantially less interest in women's activities.

Other primary sources have been used, especially the numerous correspondences and bureaucratic pamphlets of the Brothers André Fernandes and Luiz Froes, which tend to address the subjects of greatest importance to the Catholic church: marriage, spirituality and the political events leading up to the 'martyrdom' of the Missionary Jesuit Father Dom Gonçalo Silveira. Silveira himself penned an ethnographic account of the vaKaranga prior to his death, and Antonio Caiado, Damião de Goes, Diogo de Couto and Capitão-Mor Pero d'Anhaya each contributed a documentary tidbit to this thesis, as did Duarte Barbosa, although his contentions about vaKaranga 'amazons' was convincingly refuted by compatriots from nearly his own time.

The Portuguese saw what they expected to see, but it is still possible that the reality was, in fact, the same. What is certain, however, is that they rigidly imposed their own worldview on vaKaranga society, making it equally possible that they distorted reality substantially. And while Beach is being less than charitable when he says that the "prime" interest of these Jesuit humanist friars and other Portuguese writing ethnographies was monetizing their knowledge, their self-interest is evident in a number of cases. ${ }^{207}$ Generally, however, this self-interest is aimed more at advancing personal ambitions than at some semi-

${ }^{207}$ Beach, Shona and Zimbabwe, 197. 
conscious national or economic interest. ${ }^{208}$ In fact, dos Santos goes so far as to debunk assertions made by other authors regarding the extent of Mutapan territorial power in the coastal lowlands, exactly the opposite of Beach's argument that the Portuguese exaggerate Mutapan power as a means to augment their own claims to territory. ${ }^{209}$

Meanwhile, in February, 1506 Diogo de Alcaçova described Torwa and the Changamire as having been subject to the mWene we Mutapa until 1493 or $1494 .^{210}$ This letter is written a mere month after the first direct contact is made with an authority of the interior (which it is not entirely clear is Mutapa) and more than half a century before any attempt is made to coerce any interior peoples militarily. If cynical geopolitics or economics were the primary motivator for how circumstances in the interior were described it would have been far smarter policy to side with Changamire, a rebel needing legitimacy and in a position to interdict trade from his rival. ${ }^{211}$

So it has been important to tread carefully in dealing with this literature. As we will see below, however, there is actually quite a large amount of material that conventional history can contribute to gender studies on the vaKaranga, particularly when a close analysis of the text is compared to what other disciplines in the social sciences have found. Meaningfully incorporating women's history for the first time will substantially alter our understanding of

\footnotetext{
${ }^{208}$ See for instance disparate accounts by de Barros and Monclaro on the decision to march overland from Tete rather than Sofala.

${ }^{209}$ dos Santos, Ethiopia Oriental, 2:15, in Theal, Records, VII, 287.

${ }^{210}$ Letter from Diogo de Alcaçova to the King, Cochin, 1506 November 20 (Alcaçova left his post in Sofala in February), in da Silva Rego, Documentos, I, 389-401.

${ }^{211}$ As Alcaçova complained that they do quite effectively lbid.
} 
'indigenous' or 'authentic' vaKaranga gender views and the process by which they became what they are today. 


\section{Part II: The Balance of Gender Power Among vaKaranga Prior to European Contact: Historical Findings -}

Gender is in the category of ideas now considered so fundamental to human behavior as to merit specialized sub-disciplines in many fields of social science. In historiography these are called 'Social' Histories and offer, according to Joan Scott, who argued in 1986 for the relevance of gender as a member of a 'big three' paradigmatic social categories-race, class and gender-"stories of the oppressed and an analysis of the meaning and nature of their oppression and...understanding that inequalities of power are organized along at least three axes." ${ }^{212}$ Scott notes, however, that in 1986, because gender studies involved only those topics regarding interactions between the sexes, "war, diplomacy and high politics" had been assumed not to relate to gender. While she suggests ways for gender scholars to to develop this relationship, her main point is that gender is formed in ways that little reference the opposite and can be studied from the perspective of significations, formulations or exclusions, thereby both encompassing and transcending simple 'women's histories. ${ }^{213}$ vaKaranga gender and power relations, however, offer none of the obstacles to reconciling a discussion of gender and politics, even in the context of the scholarly attitudes of the middle 1980s: women's politics, and particularly diplomacy, are not only a part of the story, the gendered relationship between the male sovereign and his immediate subordinate, a mother, an aunt, a sister, a wife, or some combination thereof, had substantial influence on the dynamics and direction of state policy. ${ }^{214}$

\footnotetext{
${ }^{212}$ Joan Scott, "Gender: A Useful Category of Historical Analysis," The American Historical Review, 91, no. 5 (1986): 1054.

${ }^{213}$ Ibid., 1055.

${ }^{214}$ Pero d'Anhaya, "An Order from Pero de Anhaia, Captain-Major of Sofala, to the King's
} 


\section{Chapter 5: Women's Roles in the Economy:}

As we discussed in the previous section, the position of women in the vaKaranga economy is not entirely clear. We know that women engage in trade, although I have suggested that they likely left long-distance trade to men and stuck to buying and selling products in their local marketplaces, or were engaged in subordinate porter or 'camp follower' roles in caravans led by a man or men. We also know that senior queens of Mutapa held substantial personal estates.

Both Antonio Bocarro and Manuel de Faria e Sousa discuss these queens as they were in the early seventeenth century. Both men, however, record the same account almost word for word and it is difficult to determine who wrote the original and who plagiarized as both died "in or about" 1649 and both works were published posthumously. ${ }^{215}$ Bocarro's account includes a few more details, and phrases some things more clearly, so it has been preferred here for reproduction.

There is much to unpack from these passages, not all of it economic. For the sake of clarity, the entire passage from Bocarro is given here so that, below, shorter quotations may be made and the reader may return here to see those portions in context. As these are not the only passages of this nature, the same model will be followed for all, with sections given at length once, and other references restricted to the portions relevant to the topic then being discussed.

\footnotetext{
Treasurers, 1506 January 7" in Antonio da Silva Rego, ed., Documentos Sobre os Portugueses em Moçambique e na África Central I, trans. T. W. Baxter (Lisbon: National Archives of Rhodesia and Nyasaland, 1962), 367, Gina Buijs, "Gender and Person in African Societies: The Role of Hermeneutics," Alternation, 9, no. 1 (2002): 59-60 on Hugh Stayt, "Gender and Personhood," in The BaVenda (Oxford: Oxford University Press, 1931), 195.

${ }^{215}$ These are Theal's words introducing Antonio Bocarro, in ed. \& trans. George Theal, Records of South-Eastern Africa: Collected in Various Libraries and Archive Departments in Europe III, (London: William Clowes and Sons, 1899-1903), 254; introductory comments regarding de Faria e Sousa fix his death date precisely at 3rd June, 1649 in Theal, Records, I, 1.
} 
In the fulsome quotations, the portions relevant to the topic at hand will be set in italics and all italics will be editorial:

The monomotapa [a Latinized version of mWene we Mutapa, "king of Mutapa] has many chief wives, who are like queens. Most of them are his relations or sisters, and others are the daughters of the kings and lords who are his vassals. The principal one is called Mazarira, who is always one of the king's sisters. She is the mother of the Portuguese, speaks for them, and treats of their concerns with the king, therefore the Portuguese send their presents to her; and the monomotapa sends no ambassador to the Portuguese without one of Mazarira's servants with him. The second wife is called Inhamunda, and speaks for the Moors. The third is called Nabuiza; she is his real wife, for she is the only one who lives in the palace with the king. The fourth is called Nauemba; the fifth Nemangore; the sixth Nizingoapangi; the seventh Nemangoro; the eighth Nessanhi; and finally the ninth is called Necharunda. All these are the king's chief wives, and have houses and estates of their own, as have all the king's officers, and many lands and vassals, and some of these women have kingdoms pertaining to their houses. When one of them dies some other woman is put in her place by the king, and succeeds to her house, state, and name. They all have jurisdiction over their vassals, to punish or put them to death for their offences.

"In the houses of these women the king has many more, whom he uses at his pleasure, ordering them to come to his house, and all obey the chief wives in whose house they live, and wait upon them as their servants. The king sometimes goes to the houses of these chief wives, and sometimes commands them to come to his; but the wife he chiefly makes use of is Nabuiza, who lives in his palace with him, where she has her service and officers like the king. [end of chapter]"216

As we can see, these senior wives act as lineage matriarchs, running their economic units, the feudal fiefs attendant to their queenly title, just as other, male, lineage leaders do. If, indeed, as Bocarro and de Faria e Sousa document, these wives' holdings are legally the same "as have all the king's officers," then they control the aggregate wealth of the clans living on their

\footnotetext{
${ }^{216}$ Antonio Bocarro, Decada Composto por Antonio Bocarro: Chronista de Sua Magestade, do Estado da India, do Feitos dos Portuguezes no Oriente Capitulo CXXIII in Theal, Records III, 358.
} 
estates, not only in ivory, copper, gold and other inanimate goods, but in cattle and other livestock as well, just as male elites do. ${ }^{217}$

We see here that queens act as trade ministers to both the Portuguese and to the Swahili-aligned creoles of the interior and that no embassy is sent without the representative of the appropriate queen. ${ }^{218}$ It is also worth noting that of all the kingdoms mWene Matope Nebedza had to choose from, he put sons in charge of the territories that could interdict the "smuggling" trade from the interior, but put his daughter Mureche in control of his own best trade route to Sofala. ${ }^{219}$

In an order, dated January 31, 1506, from Pero d'Anhaya to Manoell Fernandes, factor of the king's treasures at Sofala, we see that Mutapa is not the only vaKaranga state where elite women were leading diplomats. In it, d'Anhaya gives a lengthy catalog of fine goods, charging them to the official account:

...which items [Fernandes] gave by my order to a Kaffir Queen the wife of a Kaffir King on the confines of the land of the Kaffirs who had given a warm welcome to two Christians sent by me to her house and placed herself at my orders saying that she and her husband were there in that land to serve the King our Lord... ${ }^{220}$

We have seen already that vaKaranga women were major producers of both gold, the second most lucrative export product in the economy; cultivators of cash crops like rice; and the major staple of most vaKaranga life, millet. Women were also the main producers of arguably the most lucrative manufacture in the domestic economy, machiras, or homespun, according to dos Santos. ${ }^{221}$

\footnotetext{
${ }^{217}$ Manuel de Faria e Sousa's version is found in Asia Portuguesa 2:3:15, in Theal, Records I, 24. ${ }^{218}$ Bocarro, Decada Capitulo CXXIII in Theal, Records III, 358; de Faria e Sousa, Asia Portuguesa 2:3:15, in Theal, Records I, 24.

${ }^{219}$ Beach, Shona and Zimbabwe, 162-63.

220 "Order from d'Anhaya to the King's Treasurers, 1506 January 7" in da Silva Rego, ed., Documentos I, 367

${ }^{221}$ Fr. João dos Santos, Ethiopia Oriental, 1:12, in Theal, Records, VII, 207.
} 
We have also seen that women's labor tended to be managed and directed by senior women, rather than by men. ${ }^{222}$ De Barros agrees with Bocarro and de Faria e Sousa that junior wives "wait upon" a senior queen, and also shows us that this management scheme extended to the agricultural regime, with the queen of Mutapa, rather than the lord of the realm, responsible for reviewing and inspecting the harvest: "When the harvest is ready and the crops are gathered in the queen goes to the field with them to favour their property, and this they hold to be a great honour.,"223

While Michael Bisson describes dry season copper mining campaigns organized by the master smelter or the chief of the Yeke, of the Kolwezi region on the northern border of Zambia, present-day Democratic Republic of Congo, and this is implied to stand for ores mining more generally, the Encyclopedia looks at Africa as a whole, and Yeke practices may be different from Zambezi-Limpopo mining farther south. ${ }^{224}$ We know, for instance, that women shaft miners were more common on the plateau than in Bisson. Given Sudarkasa's findings that "the purviews of female and male in African societies were often described as separate and complimentary," and Schmidt's that vaKaranga women's greatest metaphysical and memorial reverence centers on their fecundity, both in human

\footnotetext{
${ }^{222}$ Elizabeth Schmidt, Peasants, Traders and Wives: Shona Women in the History of Zimbabwe, 1870-1939 (London: Heinemann, 1992), 15-16; Paul Lane, "Engendered Spaces and Bodily Practices in the Iron Age of Southern Africa," in ed. Susan Kent, Gender in African Prehistory (Walnut Creek: AltaMira Press, 1998), 180, citing Melissa Leach, "Women's Crops in Women's Spaces: Gender Relations in Mende Rice Farming," in ed. Elizabeth Croll and David Parkin, Bush Base: Forest Farm (London: Routledge, Chapman \& Hall, Inc., 1992), 84.

${ }^{223}$ João de Barros, Da Asia : Dos Feitos Que os Portugueses Fizeram na Conquista e Descubrimento das Terras e Mres do Oriente, in Theal, Records, VI, 269; 272.

${ }_{224}$ Michael Bisson, "Copper Metallurgy," in ed. Joseph Vogel, Encyclopedia of Precolonial Africa: Archeology, History, Languages, Cultures and Environments (Walnut Creek: AltaMira Press, 1997), 128.
} 
children and in the "fecundity of the land," we can speculate (though no more than that) that the role of vaKaranga women may have been greater than just physical labor in extracting metals from the earth, as it is in extracting food. ${ }^{225}$

Three sources make some note of the value of women as economic tools, a complicated issue which, on its face, appears to objectify women in a manner that directly contradicts the thesis of this paper. This, however, is an oversimplification. Firstly, this is because women, as such, were not commodities, to be traded back and forth as fungible goods, but rather were capital assets exchanged under special circumstances. For another thing, the price being paid for the marriage was not for the woman herself as retail product, for the simple sexual or other pleasure or benefit to be derived from her presence in the husband's clan, but rather for the products of her incorporation in the husband's clan, the labor hours and the future laborers-an economically important, and not simply a semantic point. ${ }^{226}$ Dos Santos takes note of this, pointing out that "Kaffirs who are careful to choose laborious wives are the richest, and have the most provisions." 227

Once married, women were removed from the market entirely and could only be exchanged for goods by refund to their original source, their birth-clan's patriarch, and often not for the full purchase price. Once returned, the woman might marry again, however her subsequent brideprice offers might not offset her value to her birth-clan. As an economic object marked 'not for resale,' comparing

\footnotetext{
${ }^{225}$ Niara Sudarkasa, "'The Status of Women' in Indigenous African Societies," Femenist Studies 12, no. 1, (Spring 1986): 91; Schmidt, Peasants, Traders and Wives, 26.

${ }^{226}$ David Beach, The Shona and Zimbabwe 900-1850: An Outline of Shona History (London: Heinemann, 1980), 90.

${ }^{227}$ dos Santos, Ethiopia Oriental, 1:12, in Theal, Records, VII, 208.
} 
the exchange of women for other goods to a sale is inappropriate. Because rovora involved a continuing obligation to the husband's father-in-law, his tezvara, which went beyond the original goods exchanged, the closest economic analogy that can be made is to the lease of a capital asset, like an automobile or a home. ${ }^{228}$ Rayner goes into some detail refuting the notion of sale of women, noting that the woman went to live with her husband's family in vaKaranga society, but that she never took on the husband's totem herself, although her children did. When she died, her spirit was thought to return to her father's clan, making the marriage "always a "borrowing of the [non-incestuous] womb.",229

There is, however, precedent for female vaKaranga to be exchanged as commodities. This, however, explicitly excluded marriage contracts, because only the unmarried could be so exchanged and both genders were subject to trade. "These demands are called milandos among them," André Fernandes wrote in an open letter to the Jesuits of Portugal, referring to the repayment of a debt or blood-price with unmarried dependent male or female offspring. He notes the drastically higher demand in these circumstances for females than for males, saying, "usually in these cases they will not take a male because they are expensive, but the females work."230

This is a great oversimplification of the market pressures, for, in fact, the labor hours of the woman herself are not valued so much as the labor multiplier her fertile womb represents. Speaking of the dead, de Barros lists "the wife who

\footnotetext{
${ }^{228}$ Beach, Shona and Zimbabwe, 90.

${ }^{229}$ William Rayner, The Tribe and Its Successors: An Account of African Traditional Life and European Settlement in Southern Rhodesia (London: Faber and Faber, 1962, 56.

${ }^{230}$ André Fernandes to the Jesuits in Portugal, 5 December, 1562 in Theal, Records II, 145.
} 
bore many children" as the woman most likely to be given special reverence by her husband's clan. ${ }^{231}$ This value is also visible in the relative value of wives (not women, NB) over cattle. Rayner found that a single wife was worth between four and fifteen head of cattle in the first half of the twentieth century, but even more striking is the anecdote in Luiz Froes's account of the execution of Father Gonçalo Silveira: "The king asked him four questions: first, how many wives he wanted; second, if he wanted gold, third, if he wanted lands, and fourth, if he wanted cows, which according to the Portuguese from those parts are worth more than gold in that country."232 Notice that of the four questions, three are asked in the conditional tense ("if he wanted"), while the first, on the matter of wives, is quantitative ("how many"). The assumption that wives, not gold, nor even cattle, are the no-brainer gift may have escaped the celibate monks' notice, but it suggests that however great the difference in domestic values between gold and cattle, the value of wives is at least that factor again above cattle.

\footnotetext{
${ }^{231}$ de Barros, Da Asia, 1:10:1 in Theal, Records VI, 269.

${ }^{232}$ Rayner, Tribe and its Successors, 57, Luiz Froes, "Of the Voyage of the Father Dom Gonçalo to the Kingdom of Monomotapa and of his Happy Passing Away," in Theal, Records II, 120.
} 


\section{Chapter 6: Marriage, Family and Reproduction:}

We have, of course, just dealt with one of the more popular topics regarding marriage in vaKaranga society, the economic dimension, in which the historical data may be interpreted broadly in line with the conclusions others have come to through ethnographic research. The terms used to characterize the exchanges needed refinement however, because the literature shows that women are not unique in being the human objects of economic exchange, and that the only exchange that is explicitly gendered does not treat them as slaves, as some of the Portuguese writers claim.

It is often clear that these statements are as much colonizer's rhetoric as an accurate depiction of the real status of marriage relationships. Take, for instance, dos Santos's depiction of the institution:

The Kaffirs of these lands buy the women whom they marry from their fathers or mothers, giving in exchange cows, cloths, beads, or hoes, each according to his power and the value of the woman. Thus those Kaffirs who have many daughters to marry are rich, and live in contentment through them, because they have plenty to sell. If any Kaffir is discontented with his wife he may return her to her father, but forfeits the price which he paid for her; and her father or mother is obliged to receive their rejected daughter, and when she is once more in their power the marriage is dissolved, and the father may sell her to another husband. A woman may not separate from her husband, nor leave, nor reject him, because in a way she is his slave for whom he has paid. When these Kaffirs marry they have no other ceremony than an agreement between the parties, and on the day of the wedding they have great dancing, feasting, and games, at which all the inhabitants of the kraal where the wedding takes place are present. Each of the guests brings a present of millet, meal, yams, grain, beans, and whatever else they can afford or wish to contribute, all of which is given to the young couple to assist in the expense of the day, and most of these 
presents are consumed in the eating and drinking of the wedding feast.

"Every Kaffir who wishes to have two wives may do so if he can afford it, but these are very few, and therefore they only have one, except the nobles and high lords of the kingdom, for these have many, one only being the chief wife and all the rest like concubines. $^{233}$

For the most part, the first portion set in italics above is accurate and consistent with the findings of Rayner and Kuper. Divorce is socially acceptable and legal (although the ease of it is exaggerated by the Catholic Friar, consistent with the assertion made above that subjects touching on Church doctrine receive particularly biased reporting), and a full refund of the brideprice is standard, although certain qualifiers can be made by the bride's family. ${ }^{234}$ The divorcée does return to her parents' home, and is allowed to remarry. ${ }^{235}$

It is manifestly untrue, however, at least by the mid-twentieth century, that women could not initiate divorces. Even Schmidt does not contend otherwise, and because it trends against the laws and social mores of European colonial authorities, it is far more likely that dos Santos's statement is simply untrue for the sixteenth century (dos Santos's Ethiopia Oriental was published in 1609) than that any other explanation exists. In fact, André Fernandes's anecdote about milandos is about a claim by a family whose son died, supposedly because his wife left him. ${ }^{236}$ This one falsehood, whether accidental or intended, measurably distorts the apparent balance of power in the marriage relationship and therefore

\footnotetext{
${ }^{233}$ Fr. João dos Santos, Ethiopia Oriental, 1:15 in ed. \& trans. George Theal, Records of SouthEastern Africa: Collected in Various Libraries and Archive Departments in Europe VII, (London: William Clowes and Sons, 1899-1903), 212-13.

${ }^{234}$ William Rayner, The Tribe and Its Successors: An Account of African Traditional Life and European Settlement in Southern Rhodesia (London: Faber and Faber, 1962), 58.

${ }^{235}$ lbid.

${ }^{236}$ André Fernandes to the Jesuits in Portugal, 5 December, 1562 in Theal, Records II, 145.
} 
the way that balance was understood by all authorities for three hundred and fifty years. Furthermore, Monclaro, normally one of the more blatantly prejudiced sources, notes that a marriage is completed "with the consent of the father and the girl," calling dos Santos's highly male-biased depiction slightly further into question. ${ }^{237}$

As for the subsequent assertion that junior wives are "like concubines," this, like the exaggerated ease of divorce, is a statement clearly based on Catholic paradigms, which seek to delegitimize any marriage beyond the first, whether in comparatively developed societies like Arab Muslim regions, or anywhere else. ${ }^{238}$ Take, for another example of this, the statement in Bocarro (it is omitted by de Faria e Sousa) that Nabuiza is the "only one" who is the "real wife" of the mWene we Mutapa, despite the fact that Mazarira is explicitly called the "principal one."

It is certainly true enough that a clan could rise in wealth if they gave birth to a greater proportion of daughters than sons, as dos Santos says, a fact that likely further added to the demand for young women in milandos payments. ${ }^{239}$ There does not appear to be any indication that this translated to male children being exposed in any great numbers, however, nor of other population control practices, particularly ones favoring one sex over the other.

The Father Gonçalo Silveira, venerated by the church after being executed on exaggerated charges of plotting to conquer Mutapa and using

\footnotetext{
${ }^{237}$ Fr. Francisco Monclaro, Account of the Journey Made by Fathers of the Company of Jesus with Francisco Barreto in the Conquest of Monomotapa in the Year 1569 in Theal, Records, III, 230.

${ }^{238}$ dos Santos, Ethiopia Oriental, 1:15 in Theal, Records VII, 213.

${ }^{239}$ Ibid., 212.
} 
sorcery to take the kingdom by magic, notes, in one of the few surviving letters written before his death, that wives whose husbands die before they give birth are remarried to one of the husbands brothers, which some might argue is an example of the woman being treated as property to be inherited. ${ }^{240}$ Rayner, however, would disagree, interpreting it as an example of rudzwi, the valuation of the kin-group over the self, suggesting that it has little overall effect on balances of gender power. ${ }^{241}$ In this paradigm, the woman is married to the entire clan, who, after all, contribute collectively to the brideprice and benefit collectively from her labor hours and her children's produce. If she maintains an exclusive sexual relationship with one male member rather than being available to all of them, this is likely more to do sociologically with men's intra-gender status, privilege and competitiveness, or with keeping lineages straight for the purposes of observing the taboo against incest, than with concepts of property or possession.

André Fernandes tells the Jesuits in Portugal that taboos against premarital sex exist, reinforced by a myth of a deadly curse on the entire clan following from violation of the taboo. ${ }^{242} \mathrm{His}$ is, however, the only mention of such a thing, and the Jesuit Father is a less than reliable source on human sexuality, for reasons examined above. There are, though, two sources on a related topic, that of prepubescent sex, which could be interpreted as reinforcing Fernandes's claim. Damião de Goes suggests a wasting curse on all offspring of a girl who has intercourse before puberty, saying "they consider that the child of a woman who has lived with a man before such time are always sickly and of little

\footnotetext{
${ }^{240}$ Fr. Dom Gonçalo Silveira, Letter to the Jesuits of the College at Goa in Theal, Records, II, 94.

${ }^{241}$ Rayner, Tribe and its Successors, 50.

${ }^{242}$ André Fernandes to the Jesuits in Portugal in Theal, Records II, 143.
} 
vitality."243 De Barros notes only that marriage is not allowed before puberty and says that "they are accustomed to keep that day with great feasting." ${ }^{244}$ It is not clear, however, whether "that" refers to the day a promised girl has her first period (i.e. her wedding day), if all young women's first periods are so celebrated, or if he is suggesting confusedly that women go through their initiation rite at the next opportunity after they first menstruate. There may, in fact, be another, less obvious, explanation.

Young men, too, have certain taboos on their sexuality, at least elite ones in particular positions of privilege. De Faria e Sousa says that the servants and undercooks of the mWene we Mutapa are "the sons of his noblemen" and "men of quality" under twenty years of age, "for till that age they do not believe they have to do with women, and if any do they are severely punished; after that time," he goes on, "they are preferred to great employments." ${ }^{245}$ Bocarro notes the nobility of the mWene's servants, two chefs and multiple underchefs, and states that they are "between fifteen and twenty years of age," but leaves out the details about abstinence and patronage. ${ }^{246}$

De Barros and de Faria e Sousa agree that adultery was a capital crime, or rather, that it and theft are punished with equivalent severity to witchcraft,

\footnotetext{
${ }^{243}$ Damião de Goes, Chronica do Felicissimo Rei Dom Emanuel da Gloriosa Memoria (Chronicle of King Emanuel)2:10 in Theal, Records III, 129.

244 João de Barros, Da Asia : Dos Feitos Que os Portugueses Fizeram na Conquista e Descubrimento das Terras e Mres do Oriente, 1:10:1 in Theal, Records VI, 269.

${ }^{245}$ Manuel de Faria e Sousa, Asia Portuguesa, 2:3:15, in Theal, Records, 23-24.

${ }^{246}$ Antonio Bocarro, Decada Composto por Antonio Bocarro: Chronista de Sua Magestade, do Estado da India, do Feitos dos Portuguezes no Oriente Capiltulo CXXII in Theal, Records III, 356, This, of course, only makes the issue of who is copying from whom the more confused, since in one case the detail is in Bocarro, while in the other, it is in de Faria e Sousa. The most obvious answer is that each copied something from the other, but there is no way to know.
} 
which de Goes and de Barros say is a capital offense, without pardon. ${ }^{247} \mathrm{De}$ Barros also notes that both parties to adultery "pay the penalty of justice."248 It may be, however, that the 'mandatory minimum' sentences (as we call them in the present-day) were no more than submission to one of the three ordeals, chosen by the sentencing chief. Because of the perceived severity of these crimes it may have been that they were only heard by higher authorities like queens or high lords. We know that higher male elites held estates comparable to the queens, and may have had authority to try capital crimes, although Bocarro does not mention it and de Faria e Sousa compares authority of the queens to the mWene's: "They have power to reward and punish, as well as the king."249 The least severe of these would have amounted to nothing more than public shaming, no small thing in a clannal society, but substantially lighter punishment than permanent scarring of the mouth or hand, which would draw the shame out permanently (and hurt!).

The final major sexual taboo noted in the record is incest, which Beach explains is strictly enforced by means of clan totems, many of which have today become surnames in Zambia, Zimbabwe and surrounding countries. These totems, usually animals or body parts, or body parts of animals ("heart of elephant" is a major northern clan, for instance) are forbidden from marrying one another, and the rather vulgar phrase, kudya matopo, eating one's totem, is used to describe both the forbidden act of killing one's totem animal and incest. ${ }^{250}$

${ }^{247}$ de Faria e Sousa, Asia Portuguesa, 1:1:10 in Theal, Records I, 15; de Barros, Da Asia, 1:10:1 in Theal, Records VI, 269; de Goes, Chronicle of King Emanuel, 2:10 in Theal, Records III, 129.

${ }^{248}$ de Barros, Da Asia, 1:10:1 in Theal, Records VI, 269.

${ }^{249}$ Bocarro, Decada Capitulo CXXIII, in Theal, Records III, 358; de Faria e Sousa, Asia Portuguesa, 2:3:15 in Theal, Records I, 24.

${ }^{250}$ David Beach, The Shona and Zimbabwe 900-1850: An Outline of Shona History (London: 
Incest appears in the historical record more frequently, however, as a practice common among vaKaranga royalty. De Faria e Sousa points out that Ambuya (a word Schmidt translates as grandmother, strangely), which he translates as "great steward" is responsible for appointing the new Mazarira when the mWene we Mutapa's principal wife dies. The new Mazarira, however, "must be one of the king's sisters or nearest relations," he says. He also claims that all nine of the "great queens" are incestuous marriages. ${ }^{251}$ We have seen how Bocarro makes essentially the same statement, although he says that most, not all, of the senior queens are sisters or relations, while it is only Mazarira who must be from among the mWene's sisters. ${ }^{252}$

André Fernandes notes "the relationship of parent and children and brothers and sisters being the only impediment to their intercourse," but it is dos Santos who discusses incest in the greatest detail, in a section on Teve, rather than Mutapa:

This Quiteve has more than a hundred wives, all within his palace, among whom one or two are his chief wives, like queens, and the rest are but concubines. Many of these are his own sisters and daughters, whom he uses, saying that children born of them are the true heirs of the kingdom, having no admixture of alien blood, and will defend and sustain the kingdom much better than those descended from a strange people and kingdom.

"When Quiteve dies his chief wives are obliged to die also, in order to serve and dwell with him in the next world, which is another of their barbarities. In fulfillment of this inhuman law, as soon as the king is dead they take poison, which they call lucasse, kept prepared for the purpose, and so die. The king who succeeds to the throne also succeeds as husband to all the remaining wives of the former king, of whom some are his sisters, aunts, and nieces, only

\footnotetext{
Heinemann, 1980), 90.

${ }^{251}$ de Faria e Sousa, Asia Portuguesa, 2:3:15 in Theal, Records I, 23-24.

252 Bocarro, Decada Capitulo CXXIII, in Theal, Records III, 358.
} 
excepting his own mother if she is among the wives of his predecessor. This law only applies to the kings, for the other Kaffirs, though they may be great lords, cannot marry their sisters or daughters, under pain of death."253

Beach, I have noted, opines that one reason for the royal exception to the incest taboo, which non-royals violate "under pain of death," might be the avoidance of obligation to his tezvara, his father-in-law. ${ }^{254}$ If his senior wife's patriarch is himself, the reasoning would go, no other clan has a claim to privileges the mWene does not first offer himself.

This preserves property within the royal clan by more than just the savings of rovora, which the mWene can presumably afford, or else he might have cut back his marriages by a few dozen or hundred. Recalling Huffman's findings that the senior wife is exclusively privileged with looking after the patriarch's wealth, and Lane and Leach's associations of senior wives with rich farmland, we can see how senior wives coming from the royal clan could be instrumental in preserving the wealth (and thereby the power, in this tributary mode-ofproduction society), and the territorial integrity of the mWene's holdings undivided by the community fission that remained common in vaKaranga state societies even as wealth became increasingly concentrated. ${ }^{255}$ Conversely, strictly forbidding incestuous marriage among the elite would be a means to keep rival clans' wealth in a constant state of recombination.

\footnotetext{
${ }^{253}$ André Fernandes, Letter to the Jesuits in Portugal in Theal, Records II, 143; dos Santos, Ethiopia Oriental, 1:5 in Theal, Records VII, 191.

${ }^{254}$ Beach, Shona and Zimbabwe, 90.

${ }^{255}$ Thomas N. Huffman, "Expressive Space in the Zimbabwe Culture," Man, New Series, 19, no. 4 (Dec. 1984): 596; Melissa Leach, "Women's Crops in Women's Spaces: Gender Relations in Mende Rice Farming," in ed. Elizabeth Croll and David Parkin, Bush Base: Forest Farm (London: Routledge, Chapman \& Hall, Inc., 1992), 84, cited in Paul Lane, "Engendered Spaces and Bodily Practices in the Iron Age of Southern Africa," in ed. Susan Kent, Gender in African Prehistory (Walnut Creek: AltaMira Press, 1998), 180.
} 


\section{Chapter 7: Women's Access to, and Control Over, Space:}

vaKaranga women appear to have had a relatively large amount of freedom of movement and significant control over their own space. In addition to the outer ring of the settlement space in Central Cattle Plan settlements afforded to them by the metaphysical outlook of society, which also set aside the left half of the home as female space, royal dwellings seem to have had space set aside that was inviolable to men. A spacial division appears to be supported in the archaeological record of the hill enclosure at the Great Zimbabwe, according to Hall, and is clearly indicated by de Faria e Sousa and Bocarro:

The dwelling in which the monomotapa resides is very large, and is composed of many houses surrounded by a great wooden fence, within which there are three dwellings, one for his own person, one for the queen, and another for his servants who wait upon him within doors. There are three doors opening upon a great courtyard, one for the service of the queen, beyond which no man may pass, but only women, another for his kitchen, only entered by his cooks, who are two young men from among the principal lords of his kingdom, his relations in whom he has most confidence, and the lads who serve in the kitchen, who are also nobles between fifteen and twenty years of age. ${ }^{256}$

As we can see, this passage is the same quoted above regarding the mWene's footmen, and while de Faria e Sousa offers the more detail in regard to those servants, it is Bocarro who offers this greater detail about the architectural layout. Like these two, Father Monclaro notes that the mWene we Mutapa both

\footnotetext{
${ }^{256}$ Martin Hall, The Changing Past: Farmers, Kings and Traders in Southern Africa, 200-1860 (Cape Town: David Philip, 1987), 110-16; Antonio Bocarro, Decada Composto por Antonio Bocarro: Chronista de Sua Magestade, do Estado da India, do Feitos dos Portuguezes no Oriente, Capitulo CXXIII in ed. \& trans. George Theal, Records of South-Eastern Africa: Collected in Various Libraries and Archive Departments in Europe III, (London: William Clowes and Sons, 1899-1903), 356; Manuel de Faria e Sousa, Asia Portuguesa, 2:3:15 in Theal, Records I, 23.
} 
summons his wives from outlying estates on some occasions and goes to their estates himself on others. ${ }^{257}$

Dos Santos claims that vaKaranga queens were in complete control of the royal compound from the time a sovereign died until his successor ascended, and that none, particularly any potential successors, could enter the royal compound without their permission. This later point, indeed, may have applied outside of succession rites, for the language is in no way exclusive. ${ }^{258}$ Obviously this point has huge implications for female political power, and as there is a deal more to discuss in that regard, we will save textual analyses and quotations for that section, below.

It has been noted, in a previous section, that the (probable) diviner who accompanies the Mongaze army was (probably) a woman. Dos Santos says so, as do de Couto and de Faria e Sousa, while Monclaro, who de Couto documented as having animus against Francisco Barreto, dissents from the story common among the other three that Barreto recognized that the diviner was casting some sort of spell before the battle, ordered a falçon field artillery piece leveled at the diviner and rewarded the chief gunner's successful shot with a gold chain from around his own neck. ${ }^{259}$ In Monclaro's version, in which he skips the battle's opening so as "not to delay too long upon this matter, which has not much bearing on the subject," he refers to the wizard with the masculine noun

${ }^{257}$ Fr. Francisco Monclaro, Account of the Journey Made by Fathers of the Company of Jesus with Francisco Barreto in the Conquest of Monomotapa in the Year 1569 in Theal, Records III, 229.

${ }^{258}$ Fr. João dos Santos, Ethiopia Oriental, 1:5 in Theal, Records VII, 192.

259 de Faria e Sousa, Asia Portuguesa, 2:3:16, in Theal, Records I, 27; Diogo de Couto, Da Asia: Of the Deeds Which the Portuguese Performed in the Conquest and Discovery of the Lands and Seas of the East, Capitulo XXIII in Theal, Records VI, 376; dos Santos, Ethiopia Oriental 2:6, in Theal, Records VII, 263; Monclaro, Account in Theal, Records, III, 243. 
ending and pronouns, but does not specifically call him 'homem' as the others call her 'mulher velho,' 'old woman.' He returns to the subject of the wizard only after the battle, saying merely that he was among the dead, having had his jaw blown away by a musket ball and dropped his gourd of medicine dust. ${ }^{260}$

The matter of Monclaro's diminishment of Barreto's leadership and selfserving obfuscation, indeed, has not terribly much bearing on our subject, that of women's access to space, except in that the woman diviner's presence or not on the field stands in dialogue with de Barros's statement that:

While they are engaged in war they do not wash their hands or faces, as a sign of sorrow, until they have gained the victory over their enemies, neither do they take their women with them, for these are so loved and venerated that should the king's son meet any woman on the road he must stand still and make way for her to pass. ${ }^{261}$

Probably, de Barros's comment is true as a general rule, although Monclaro refers to "negresses," a literal translation by Theal, as enslaved camp followers to the Portuguese invasion force, a passage that has its own problems, as it shows open disdain for the African allies of the Portuguese, the Chombe, suggesting exaggeration. ${ }^{262}$

Even if we accept de Barros, however, it must be with the caveat that, in isolated circumstances, women have some role in warfare and individual women, for one reason or another, might accompany a vaKaranga army. Further, it requires attention that Duarte Barbosa (apparently mistaking the translation of Sono for a description of his soldiers), claims that the mWene we Mutapa

\footnotetext{
${ }^{260}$ Monclaro, Account in Theal, Records, III, 243.

261 João de Barros, Da Asia : Dos Feitos Que os Portugueses Fizeram na Conquista e Descubrimento das Terras e Mres do Oriente, 1:10:1 in Theal, Records VI, 272.

${ }^{262}$ Monclaro, Account in Theal, Records III, 424.
} 
"constantly takes with him into the field a captain whom they call Sono, with a great number of people, and five and six thousand women who also bear arms and fight."263 This misconception, however, is among the mistakes that dos Santos corrects, along with the aforementioned territorial extent of Mutapan coastal holdings. ${ }^{264}$

Beach notes that women wear the majority of copper and gold, especially beads, but also wire and beaten bracelets, anklets and armlets, a sort of control of material wealth and of their appearance that, although minor, is reflected in the primary sources. ${ }^{265}$ Barbossa, writing early and with inferior access to affluent communities in the interior (and, as we just saw, to reliable informants), says of "The Great Kingdom of Benemetapa" that, "They are men of war, and some of them are great traders; their women go naked, only they cover their loins with cotton cloths while they are single, and when they are married and have children they throw other cloths over their breasts."266

André Fernandes agrees with this description of peasant dress, saying, "their dress, speaking of the [male] courtiers, (for the rest a skin of an animal in front and another at the back), is a piece of calico..." He goes on to describe male elites' dress in greater detail and then moves on to that of wealthy women:

The women wear a piece of cloth which I think well suited to them, it is not very long, and over it they wear many strings of different coloured beads twisted together in front, and arranged to fall one below the other at the back. They wear all sorts of finery, such as

\footnotetext{
${ }^{263}$ Duarte Barbosa, Livro em que Dá Relacão do que Viu e Ouviu no Oriente (manuscript), in Theal, Records I, 95-96.

${ }^{264}$ dos Santos, Ethiopia Oriental, 2:15 in Theal, Records VII, 287.

265 David Beach, The Shona and Zimbabwe 900-1850: An Outline of Shona History (London: Heinemann, 1980), 98.

${ }^{266}$ Barbosa, Livro, in Theal, Records I, 95.
} 
crowns and circlets, on their heads, which are half shaved, but the men's heads are not fit to be seen... ${ }^{267}$

Monclaro merely notes the wire bracelets and anklets, "drawn very fine," of both copper and gold, and attributes them specifically to women. ${ }^{268} \mathrm{De}$ Barros, however, offers an interesting detail. "Though Benomotapa is king of this country and lord of all, and his wives are dressed in these cloths," he says, referring to machiras, Indian cotton cloths, and silks with thread of gold, "no cloth of foreign manufacture can touch his person, but all must be made in the country."269

Above we noted an aphorism recorded by dos Santos, in reference to the men's hairstyles that André Fernandes called "not fit to be seen."270 "They make great sport of a man who wears no horns [sculpted from his hair]," dos Santos says, by way of introduction, "saying that he is like a woman, because a man being the male should have horns, thus comparing themselves to the wild animals among which the female has no horns." ${ }^{271}$ While, on the surface, this seems indicative of a society in which men leverage their greater physicality to dominate women in a very complete fashion, it contrasts rather starkly with de Barros's statement that the reason women are not brought on military campaigns and are given right-of-way on the roads is because "these are so loved and venerated."272

Granting that many societies that are highly patriarchal show a

${ }^{267}$ André Fernandes to Luiz Froes at Goa in Theal, Records II, 75-76.

${ }^{268}$ Monclaro, Account in Theal, Records III, 229.

${ }^{269}$ de Barros, Da Asia, 1:10:1 in Theal, Records VI, 270.

${ }^{270}$ André Fernandes to Froes in Theal, Records II, 76.

271 dos Santos, Ethiopia Oriental, 1:12 in Theal, Records VII, 207.

272 de Barros, Da Asia, 1:10:1 in Theal, Records VI, 272. 
comparable focus on superficial courtesy toward women while treating them abusively by institution and in practice, the connection between the love and veneration of women and the overt gestures of respect that are social norms is plausible. Women, after all, were relatively rare outside of the elites' compounds and would therefore have been highly valued. The 'motive' and/or the 'prize' in a great number of the folk stories collected by Hugh Tracy at the last turn of a century, is in fact nothing else but the return of wives to the father's compound, most vividly illustrated by the community of unmarried women living imprisoned underground by a witch, which the protagonists free and bring home to their village in the "The Snake Who Bit a Girl."273

After all, we also know that 'wife' to the mWene we Mutapa was among those titles the vaKaranga were observed to have "a great veneration for."274 This is a small, opaque issue, but it appears to be one more stick on the bonfire illuminating a relatively high status for women in vaKaranga society. And truly, one could imagine that a man might be careful of using his horns, regardless of how proud he is of them, or of how much time he spends measuring them against other men, if doing so might cost him his wife and half or more of the deposit he paid for her if her family agrees that he has been heavy-handed. ${ }^{275}$

Lastly, before we move on to women's roles in religion, is the issue of the privileges a wife is entitled to. This is an arcane assertion, stemming from a rather strange anecdote in dos Santos's Ethiopia Oriental. Its relevance and

\footnotetext{
${ }^{273}$ Hugh Tracey, The Lion on the Path: and Other African Stories (London: Routledge \& Kegan Paul, 1967), 6-22.

${ }^{274}$ dos Santos, Ethiopia Oriental, 1:20 in Theal, Records VII, 225.

${ }^{275}$ See Beach, Shona and Zimbabwe, 90 for instance, on this.
} 
value may be negligible, or it might be substantial. It has been included in this section for lack of a better place for it (as, to some extent, the preceding discussion of dress has been), and it has been reserved for the end of the section because, while it addresses the status of women (albeit in a highly tangential fashion), it is not clear what, if anything at all, it says about it. In short, it is here because it belongs somewhere in the conversation, but it is not at all clear where.

It has been noted above that the formal titles of 'wife' and 'great wife' to sovereigns were high honors in vaKaranga society, akin perhaps to a knighthood bestowed by the King or Queen of England. ${ }^{276}$ A Portuguese named Rodrigo Lobo, a prazeiro given title to a large island in the middle of the Zambezi by the quiTeve, was among those bestowed with this title, according to dos Santos. The island was famous for its easy hunting, and on one occasion a large cache of game was killed after being driven together by beaters. When a lion was found to be among the carcasses, Lobo was obliged to think fast. ${ }^{277}$ quiTeve at the time held the praise name 'Great Lion,' and the animals were therefore his personal mascot and protected except in hunts for his pleasure. Sensitivity to his new sovereign's culture and the clever punning his host-countrymen so admired, however, illustrate vividly the respect and privileges due to a 'Wife' of quiTeve.

Lobo presented the dead lion to quiTeve as a gift, along with twenty bolts of cloth. Exhibiting rather masterful understanding of vaKaranga society, Lobo

\footnotetext{
${ }^{276}$ dos Santos, Ethiopia Oriental, 1:20 in Theal, Recrods VII, 225.

${ }^{277}$ Ibid., 225-27.
} 
claimed he was engaged in women's duties (harvesting crops) when he killed "this rebellious and discourteous lion" with, he claims, a hoe (symbolically a woman's tool). ${ }^{278} \mathrm{He}$ added that he was sending the carcass to quiTeve "that he might take further vengeance upon it for the offence it had done to his wife. Quiteve accepted the present," dos Santos tells us, "and sent him word that he had done well to kill the lion, since it was discourteous to his wife."279

There is obviously a lot about this story that is unique to the circumstance, not least of which being the ethnicity of Rodrigo Lobo and the diplomatic concerns involved in punishing him. How much of the privilege indulged by quiTeve would have applied to a vaKaranga Wife? And how much more (or less) would have applied to a Tevan Queen? It is impossible to say, and the episode stands as more a question than an answer.

\footnotetext{
${ }^{278}$ dos Santos, Ethiopia Oriental, 1:20 in Theal, Recrods VII, 225-27.

${ }^{279}$ lbid.
} 


\section{Chapter 8: Women in Religious Life:}

Religion in vaKaranga life prior to European contact is even more opaque than other subjects, not only because the Portuguese immediately set about moralizing and converting the locals everywhere they went, but because, as Beach notes, some of the features of the religion in the sixteenth century that appear to be more or less accurately documented are no longer apparent by the 20th century. ${ }^{280}$

There is nothing on women in religion in the primary literature that has not been discussed in one section or another above, excepting a passing mention by Monclaro wherein an mWene we Mutapa, having gone to visit one of his wives' estates, "returned with a headache," whereon, "they say he ordered more than four hundred [of his reputed more than 3000 wives] to be put to death, asserting that they had cast spells upon him."281 This is likely apocryphal, especially coming from Monclaro, and hardly suggests more than that wives had a reputation for doing minor domestic sorcery around the home..$^{282}$

Monclaro also relates that the senior wives of sovereigns commit suicide by lucasse when their husband dies, "saying that they must go and serve him in the other world." ${ }^{283}$ However, Monclaro's particular willingness to report anything

\footnotetext{
${ }^{280}$ David Beach, The Shona and Zimbabwe 900-1850: An Outline of Shona History (London: Heinemann, 1980), 104.

${ }^{281}$ Fr. Francisco Monclaro, Account of the Journey Made by Fathers of the Company of Jesus with Francisco Barreto in the Conquest of Monomotapa in the Year 1569 in ed. \& trans. George Theal, Records of South-Eastern Africa: Collected in Various Libraries and Archive Departments in Europe III, (London: William Clowes and Sons, 1899-1903), 229.

${ }^{282}$ Michael Gelfand, The African Witch: With Particular Reference to Witchcraft Beliefs and Practice Among the Shona of Rhodesia (Edinburgh: E \& S Livingstone, 1967), 67.

${ }^{283}$ Monclaro, Account in Theal, Records III, 229.
} 
scandalous or salacious about the vaKaranga is here further filtered through the hearsay of a creole Muslim, leaving Monclaro himself dubious enough to record the provenance ("this I heard only from a negro who partakes a good deal of the Moor"). ${ }^{284}$ Dos Santos, paradoxically one of the most reliable sources and perhaps the most blatantly racist in the primary literature for this part of Africa, plagiarizes Monclaro's statement but goes on to discuss a major role the senior wives play in successions (see introduction). ${ }^{285}$

We discussed the curse supposed to affect the entire families of women who have sex out of wedlock, but perhaps it is relevant enough to note that it is believed that this curse can be countered by means of charms and talismans, while on the other hand, the wasting curse on the children of women who have pre-pubescent sex, apparently, cannot. ${ }^{286}$ The suggestion is that even if taboos against extramarital sex are exaggerated, as they very well could be by the writers we are dealing with, they can still be shown to be less severe than other taboos.

André Fernandes comments to a number of his correspondents on the greater popularity of Catholic teachings among vaKaranga women than men, although the reasons for this are rather hopelessly obscure. ${ }^{287}$ "The women show great devotion to the image of our Lady and all the other images," he tells Luiz Froes, which may suggest a fascination with the relatively sophisticated

\footnotetext{
${ }^{284}$ Monclaro, Account, in Theal, Records III 229-30.

285 João dos Santos, Ethiopia Oriental, 1:5 in Theal, Records VII, 191.

${ }^{286}$ André Fernandes to Jesuits in Portugal, 5 December, 1562 in Theal, Records II, 143; Damião de Goes, Chronica do Felicissimo Rei Dom Emanuel da Gloriosa Memoria (Chronicle of King Emanuel), 2:10 in Theal, Records III, 129.

${ }^{287}$ André Fernandes to the Jesuits of the College at Goa in Theal, Records II, 88.
} 
visual arts, with the appearance and dress of the almost entirely unknown women of Europe, or a number of other possibilities too invisible to guess. ${ }^{288}$ To the Father Provincial in Goa he notes that "things which appeal to their eyes make a great impression on them."289

Finally, there is the matter of the presumed diviner who accompanies the Mongaze army. There is little more to say about her, except to note the powers she was reputed to have, which are by no means an exhaustive list. We know only that she carried a gourd in which the components of a great spell were already mixed and rendered in a powdered form, and that she was thought to be immortal. ${ }^{290}$ The spell, we are told, was meant to render its targets somehow incapacitated, with de Couto and dos Santos agreeing that this was to be by blindness. The real effects cannot be known because the spell was interrupted by the Portuguese chief gunner, however, as the diviner was killed by the shot, we can say for certain that she was not immortal.

\footnotetext{
${ }^{288}$ André Fernandes to Luiz Froes at Goa in Theal, Records II, 74.

${ }^{289}$ André Fernandes in a letter to the Father Provincial in Goa in Theal, Records II, 65.

${ }^{290}$ Manuel de Faria e Sousa, Asia Portuguesa, 2:3:16, in Theal, Records I, 27; Diogo de Couto, Da Asia: Of the Deeds Which the Portuguese Performed in the Conquest and Discovery of the Lands and Seas of the East, Capitulo XXIII in Theal, Records VI, 376; dos Santos, Ethiopia Oriental 2:6, in Theal, Records VII, 263; Monclaro, Account in Theal, Records, III, 243.
} 


\section{Chapter 9: Women in vaKaranga Political Life:}

So now we come to the crux of the argument. In some manner or another, of course, almost all of what has been discussed above plays to the political power or status of vaKaranga women. In addition to the nine great queens listed by Bocarro and de Faria e Sousa, Bocarro includes a "Mungussy, [of] the kingdom of Inhacanemba, great wife of Monomotapa" in his list of the sub-rulers of Mutapa. ${ }^{291}$ There is nothing to say one way or the other if Mungussy is a male wife or a queen, as the Portuguese word reino ('realm,' as much as 'kingdom') is simply a masculine noun, and does not change classes based on the gender of the sovereign.

We recall that the queens, according to Bocarro, "have jurisdiction over their vassals, to punish or put them to death for their offences," and that their estates are alike to those of the highest lords, that they have "many lands and vassals," among whom are men, and that some have whole districts under their control. ${ }^{292}$ We know that the senior queens commanded the labor of junior queens who, according to Monclaro, did farm labor as well as household service.

We know that women have the right of way on the road, a very minor sort of power, and we can say that queens did not have the power to name their own successors. ${ }^{293}$ The Ambuya, the chief steward or chief major-domo was said to be responsible for doing so, at least as far as Mazarira was concerned. This may

\footnotetext{
${ }^{291}$ Antonio Bocarro, Decada Composto por Antonio Bocarro: Chronista de Sua Magestade, do Estado da India, do Feitos dos Portuguezes no Oriente, Capitulo CXXIII in ed. \& trans. George Theal, Records of South-Eastern Africa: Collected in Various Libraries and Archive Departments in Europe VII, (London: William Clowes and Sons, 1899-1903), 356.

292 lbid., 358. The noun form indicates a mixed group.

293 João de Barros, Da Asia : Dos Feitos Que os Portugueses Fizeram na Conquista e Descubrimento das Terras e Mres do Oriente, 1:10:1 in Theal, Records VI, 272.
} 
have been true for the rest of the wives, for Bocarro says that the mWene names their successors. We also know that the mWene we Mutapa sent no embassies without a representative of whichever queen had the trade minister portfolio for the foreign power. ${ }^{294}$

Antonio Caiado and Luiz Froes illustrated how the queen holding the position that would later be referred to as Mazarira was among the mWene we Mutapa's most trusted advisors, for not only does he summon her to the deliberations on how to deal with the perceived threat of Father Silveira, she is the only other person in the mWene's first meeting with Silveira. This meeting took place in "a house of his to which no one is ever admitted, and there [he] made him sit on a carpet between himself and his mother, while Antonio Caiado stood in the doorway to act as interpreter."295

It seems possible that, excluding the sovereign, whose succession is more complicated and will be discussed below, the claims of de Goes and de Barros, that the senior wife's sons inherit, is at least close to the mark. ${ }^{296}$ Keeping in mind that a man with multiple wives is likely also a man of property, his sons might well have enough land and property to distribute control, if not full ownership, to all or many of the junior wives' sons. ${ }^{297}$ Monclaro, it should be

\footnotetext{
${ }^{294}$ Bocarro, Decada, Capitulo CXXIII in Theal, Records III, 357-58; Manuel de Faria e Sousa, Asia Portuguesa, 2:3:15 in Theal, Records I, 24.

${ }^{295}$ Antonio Caiado, "Letter from Monomotapa to one of his friends in another part of that country" in Theal, Records II, 103; Luiz Froes, "Of the Voyage of the Father Dom Gonçalo to the Kingdom of Monomotapa and of his Happy Passing Away," in Theal, Recrods II, 120. It is difficult to decide if the sources are reliable, either in saying that Mazarira is a title rather than the contemporary queen's name, or in calling the earlier queen the mother of the contemporary mWene. ${ }^{296}$ Damião de Goes, Chronica do Felicissimo Rei Dom Emanuel da Gloriosa Memoria (Chronicle of King Emanuel), 2:10 in Theal, Records III, 129 and de Barros, Da Asia, 1:10:1 in Theal, Records VI, 269.

${ }^{297}$ Gerald Chikozho Mazarire, "'The Politics of the Womb': Women, Politics and the Environment
} 
noted, splits the difference somewhere between de Goes/de Barros and dos Santos's description of royal succession, referring to a "principal wife," but not claiming that she is the first. ${ }^{298}$

We recall, of course, that the queen is responsible for the cultivation of crops on a managerial level throughout the state, as evidenced by de Barros's testimony about inspections and by Rodrigo Lobo's use of the lie, recounted by dos Santos, that he was playing the role of quiTeve's wife at the time the lion attacked. ${ }^{299}$ Women also make what numerous scholars believe is the most valuable manufacture in the domestic economy, machiras cloth, the cotton homespun..$^{300}$

We know that women have the power to initiate divorces, contrary to what dos Santos tells us, because we have seen André Fernandes's testimony that a court case was triggered when a man died shortly after his wife left him. ${ }^{301}$ We also know that elite women are treated with "great veneration," because the respect shown to those honored by the sovereign is "as much courtesy" as is given to the sovereign's wife..$^{302}$

We know that vaKaranga queens had authority to speak on their husbands' behalf, given the evidence of d'Anhaya's order to Manoell Fernandes, and we know that vaKaranga queens held substantial power even in territories

\footnotetext{
in Precolonial Chivi, Southern Zimbabwe, c.1840 to 1900," Zambezia XXX, no. i (2003): 48.

${ }^{298}$ Fr. Francisco Monclaro, Account of the Journey Made by Fathers of the Company of Jesus with Francisco Barreto in the Conquest of Monomotapa in the Year 1569 in Theal, Records III, 229.

${ }^{299}$ de Barros, Da Asia, 1:10:1 in Theal, Records VI, 272; João dos Santos, Ethiopia Oriental, 1:20 inTheal, Records VII, 272.

300 lbid., 1:12, 207.

${ }^{301}$ André Fernandes to the Jesuits in Portugal, 5 December, 1562 in Theal, Records II, 145.

${ }^{302}$ dos Santos, Ethiopia Oriental, 1:20 inTheal, Records VII, 272.
} 
that were not large enough to delegate responsibility to governors and distribute estates. $^{303}$ Mureche of Barwe's marriage cannot have been terribly far from the normal balance of power in a relationship between elite men and their senior wives, otherwise her lineage would have been extremely unlikely to survive the arrival of the Portuguese, in hostile territory and among ethnic and linguistic foreigners as they were. ${ }^{304}$

The most important power women held in vaKaranga society was the power that queens had in the succession of sovereigns. Central Cattle Plan societies generally obey a loose set of rules for kin based succession, with an underlying "best fit to lead" philosophy and a consensus usually made obvious by the dying king's blessing, but sometimes disputed afterward in the 'colleges' of elders and of the dead king's wives. ${ }^{305}$

Dos Santos devotes more than a chapter to the role the college of wives plays in the succession, replete with an anecdote as detailed as that recounting Rodrigo Lobo's story. The account is at the top of this thesis, the block of text one might need four stomachs to digest. A skim of the italics, my editorial change, was designed to highlight the elements of the story we are interested in, and the story tells much about the power vaKaranga women were able to leverage, even in the face of male physical coercion. ${ }^{306}$

\footnotetext{
${ }^{303}$ Pero d'Anhaya, "An Order from Pero de Anhaia, Captain-Major of Sofala, to the King's Treasurers, 1506 January 7" in Antonio da Silva Rego, ed., Documentos Sobre os Portugueses em Moçambique e na África Central I, trans. T. W. Baxter (Lisbon: National Archives of Rhodesia and Nyasaland, 1962), 367; de Barros, Da Asia, 1:10:1 in Theal, Records VI, 272.

${ }^{304}$ David Beach, The Shona and Zimbabwe 900-1850: An Outline of Shona History (London: Heinemann, 1980), 163.

${ }^{305}$ dos Santos, Ethiopia Oriental, 1:5-6 in Theal, Records VII, 192-93; Caiado to a friend in Theal, Records II, 103; Beach, Shona and Zimbabwe, 59.

${ }^{306}$ dos Santos, Ethiopia Oriental, 1:5-6 in Theal, Records VII, 192-93.
} 
The sovereign, under normal circumstances, has indicated his chosen successor, and he is interred in a cave on a mountaintop with his predecessors on the same day he dies. The next day, the successor goes to take possession of the palace, which he can only do with the consent of the wives. When he is installed, a ceremony follows in which the high lords pledge fealty to the sovereign, who remains concealed behind a curtain until after the oath has been made, at which point he reveals himself, with the senior wives beside him to signify their consent. At times, according to dos Santos, intrigue, bribes and political machinations lead to other successors ascending, and a common form is to secure the consent of the wives and take possession of the palace in the night. 'Whoever enters by violence and takes possession against [the wives'] will lose his right of succession to the kingdom," dos Santos says, and "no one has the power to oppose the election made by the wives." ${ }^{307}$

As proof, dos Santos describes the succession of Danda, which took place when he was in the area. The sovereign had indicated one heir, but the wives admitted another, forcing the legitimate claimant to flee. The legitimate claimant had wide popular support and gathered an army, but, for whatever reason, he forced entry into the palace. Dos Santos does not specify what the legitimate manner of procedure would be, one might guess starvation if the possessor of the palace cannot be induced to give battle, but apparently even the legitimate claimant's own allies were scandalized at his breach of protocol and abandoned him, leaving the kingdom to the wives' pick. ${ }^{308}$

\footnotetext{
${ }^{307}$ dos Santos, Ethiopia Oriental, 1:5-6 in Theal, Records VII, 193.

${ }^{308}$ Ibid.
} 
It would certainly be difficult to credit this assertion if it were made in the absence of corroboration, particularly given that it comes from only one source. It seems, in its way, more far-fetched than some claims which have been dismissed as unlikely above. Dos Santos is, however, more blatantly derogatory, more openly disdainful of Africans in many regards, than any source quoted in this section, describing the birthing practices of vaKaranga women, for instance, as "as wild as savage beasts or sylvan animals... as if they were she-goats," and it is he who recounts the joke about men having horns. ${ }^{309}$ Even Monclaro, whose unreliability has been used almost as a watchword above, is more sensationalist than blatantly demeaning, at least by comparison with dos Santos. Dos Santos has, conversely, been considered among the more reliable sources in this study, furnishing more useful passages, at greater length and with profounder depth of detail than any other author. Given his particular propensity for displays of misogyny, and that the anecdote fits his pattern of explicit detail, which has many times been corroborated by twentieth century ethnography, this description of an unprecedented female role in succession politics should be viewed as a powerful final statement on the overall balance of gender power in vaKaranga society.

${ }^{309}$ dos Santos, Ethiopia Oriental, 1:15 in Theal, Records VII, 213. 


\section{Conclusions:}

vaKaranga society was clearly patriarchal. The self-described radical feminists who wrote about African and vaKaranga gender in the 1990s, however, have mischaracterized it in treating it as "extreme" in this regard. To some extent this is already evident in the secondary sources, which focus heavily on anthropological and twentieth century historical sources. It is not a coincidence, however, that the more use a scholar makes of the Portuguese documents, the more moderate their views tend to be on vaKaranga male dominance. The trend goes from Courville, who does not even include Theal's Records of South-East Africa in her bibliography, to Schmidt, who uses Records and da Silva Rego's Documentos Sobre os Portugueses em Moçambique e na Africa Central sparingly and authored the "extremely patriarchal" statement, through Lancaster, who is familiar enough with the Records that he might have spent his evenings in the field with a set of the books by his bed, reading them by firelight. ${ }^{310}$

The study has demonstrated some of the shortcomings of the existing historiography with respect to gender. Schmidt contradicts herself regarding women's ability to be muhondoro mediums, and she deemphasizes evidence that does not support her argument, even while recording numerous positions of power held by women-too numerous to be the anomalies she claims they

\footnotetext{
${ }^{310}$ Chet S. Lancaster, The Goba of the Zambezi: Sex Roles, Economics and Change (Norman: University of Oklahoma Press, 1981), 344; Elizabeth Schmidt, Peasants, Traders and Wives: Shona Women in the History of Zimbabwe, 1870-1939 (London: Heinemann, 1992), 259-74 cites only vol. 3 of Theal vs. six pages of bibliographic entries of interviews and British archival documents; Cindy Courville, "Re-Examining Patriarchy as a Mode of Production: The Case of Zimbabwe" in eds. Stanlie James and Abena Busia, Theorizing Black Feminisms: The Visionary Pragmatism of Black Women (London: Routlege, 1993), 42-43, cites neither da Silva Rego, nor Theal.
} 
are. ${ }^{311}$ Courville's gender associations with class are not supported, single men are far more marginalized than the 'peasantish' class of women, the village single or junior wives, with single women rare. ${ }^{312}$ Kuper's characterization of the brideprice exchange is very explicit, not 'women for cattle,' only wives. ${ }^{313}$ Beach argued that vaKaranga queens were independently powerful, not dependent on their husbands' statuses as Schmidt argued..$^{314}$ Lancaster recorded a history of Middle-Zambezi Goba that involved relatively minor social upheaval in the migration from patriarchal mainstream Shona society, to a matriarchy on the margins, a natural political leverage of powers, not a revolutionary seizure. ${ }^{315}$ This change, it is noted, was nowhere near drastic enough to make the MiddleZambezi Goba seem like outsiders to their patriarchal cousins on the south banks, and an overwhelming majority of Middle-Zambezi Goba social practices remain representative of mainstream Shona practices.

I have examined how Lane characterized senior wives as controllers of choice farmland, and how women dominated the mining workforce if not the management of the industry. ${ }^{316}$ And while we have acknowledged the nominal

\footnotetext{
${ }^{311}$ Schmidt, Peasants, Traders and Wives, 24-29.

${ }^{312}$ Courville, "Re-Examining Patriarchy as a Mode of Production" in James and Busia, Theorizing Black Feminisms, 32 says that her "perspective constructs a gender-relations-based class society, in which a 'class of patriarchs' owns and controls the means of production and a 'dependent class' of workers, comprised of wives, unmarried daughters and younger sons, provides the labor." I have shown that the class of owners includes roughly equal numbers of queens and patriarchal higher lieutenants, and that each hierarchical step zags back or forth across the gender divide.

${ }^{313}$ Adam Kuper, Wives for Cattle: Bridewealth and Marriage in Southern Africa (London: Routledge \& Kegan Paul, 1982).

${ }^{314}$ David Beach, The Shona and Zimbabwe 900-1850: An Outline of Shona History (London: Heinemann, 1980), 90.

${ }^{315}$ Lancaster, Goba of the Zambezi, 13-20.

${ }^{316}$ Melissa Leach, "Women's Crops in Women's Spaces: Gender Relations in Mende Rice Farming," in ed. Elizabeth Croll and David Parkin, Bush Base: Forest Farm (London: Routledge, Chapman \& Hall, Inc., 1992), 84, cited in Paul Lane, "Engendered Spaces and Bodily Practices in
} 
male ownership of these means of production, we have also shown how this ownership depended on continued female engagement on this property. ${ }^{317}$

In addition, I have shown how Beach refutes the assertion that women were not involved in the marketing and sale of the products of their labor, and I suggested that women played the major role in local commerce, while men engaged in long-distance trade. ${ }^{318}$ This suggestion was made by extrapolation of the pattern apparent in the record by which women have relative freedom of movement within their home territories (or their husbands' clans', rather), while men commonly travelled over much greater areas due to their roles as herders, hunters and warriors. We have also discussed the importance of Huffman's finding that senior wives husband the family's inanimate savings. ${ }^{319}$

I also discussed the fact that a man's obligation to his tezvara, his fatherin-law, does not end with the payment of his wife's rovora. This has shown the power a wife and her family can wield over their in-law, and illustrates the significantly higher value a wife is acknowledged to have versus inanimate (or inhuman) commodities. ${ }^{320}$ Furthermore, the importance of the constellation of women's management of land-laborers, control over their husband's stockpile of resources, and position as the guarantor of the familial alliance consummated by her marriage is underlined by the royal strategy of incestuous first marriages for concentrating and protecting the wealth of the royal clan. ${ }^{321}$

the Iron Age of Southern Africa," in ed. Susan Kent, Gender in African Prehistory (Walnut Creek: AltaMira Press, 1998), 180.

${ }^{317}$ William Rayner, The Tribe and Its Successors: An Account of African Traditional Life and European Settlement in Southern Rhodesia (London: Faber and Faber, 1962), 62.

${ }^{318}$ Beach, Shona and Zimbabwe, 91.

319 Thomas N. Huffman, "Expressive Space in the Zimbabwe Culture," Man, New Series, 19, no. 4 (Dec. 1984): 596.

${ }^{320}$ Beach, Shona and Zimbabwe, 90.

${ }^{321}$ lbid., 96. 
Next, I examined the account in Beach's survey, of a lineage founded by means of a dowry, in apparent contravention of the tradition of rovora, and of political good sense, concluding that the senior partner in the alliance, Mutapa, must have had some guarantee of influence in the territory that would seem to be unaccounted in the record (which Beach considers reliable, narratively, exclusively for answering such political questions). ${ }^{322}$ Given that the same mWene we Mutapa who gave Barwe to his daughter Mureche also gave away territory to four sons, including at least two territories inferior to Barwe, and that the only information on the transfer is the existence of a dowry and its recipient Mureche, there was little choice but to conclude that Mureche herself was guarantee enough that Barwe would remain independent of the power of the junior partner, Teve. ${ }^{323}$ This would not be possible in a society in which women were disproportionately controlled by men and whose status was "mediated by men." ${ }^{324}$ It is likely that it would only have been possible if Mureche was the ultimate sovereign (shadow or public) during her lifetime, guaranteeing that power passed to her own son, as we know it eventually did.

I explored the importance of wives, particularly junior wives, as multipliers of the clan's labor force, and the role a plurality of daughters could play in upward social mobility. ${ }^{325}$ Elder women's roles as the primary conduit for the reproduction of knowledge and the social memory, and their influence as

\footnotetext{
${ }^{322}$ Beach, Shona and Zimbabwe, 163.

${ }^{323}$ Ibid., 162.

${ }^{324}$ Schmidt, Peasants, Traders and Wives, 29.

${ }^{325}$ Rayner, Tribe and its Successors, 56; João dos Santos, Ethiopia Oriental, 1:15 in ed. \& trans. George Theal, Records of South-Eastern Africa: Collected in Various Libraries and Archive Departments in Europe VII, (London: William Clowes and Sons, 1899-1903), 212.
} 
stabilizing factors in the social contract, as the primary source of advice for newly married women, were also discussed. ${ }^{326}$

Exterior signifiers, like the prioritization of protection for male-associated markers of wealth, or much-quoted rhetorical statements, belied deeper negotiations between gender and status in which status takes precedence. ${ }^{327}$ I discussed how the perceived spiritual potency of women put them in positions to exert power in religious and other metaphysical roles, from diviners and witches, to midwives, to rainmakers to spirit mediums. ${ }^{328}$

The discussion of Bujis's example of female power in the makhadzi showed that the status of vaKaranga women in Mutapa not only extended to Khami, but survived to the twentieth century in a region that was only indirectly influenced by European society until the Scramble. ${ }^{329}$ Women held an influential advisory role in the succession of royal dynasties, according to Beach, and Huffman states that they continued to be executors of their brothers' estates in all classes in the late twentieth century. ${ }^{330}$ And the addition of symbolic femininity to a man's identity was used in a variety of ways to enhance his status. ${ }^{331}$

Through this point, we are only dealing with the evidence that exists in the secondary sources, much of which supports the argument that vaKaranga

\footnotetext{
${ }^{326}$ George Fortune, ed., Ngano, vol. 2 (Salisbury: University of Rhodesia, Department of African Languages, 1974), xi, cited in Schmidt, Peasants, Traders and Wives, 23.

${ }^{327}$ Thomas N. Huffman, "Archaeology and Ethnohistory of the African Iron Age," Annual Review of Anthropology, vol. 11 (1982): 140-41.

${ }^{328}$ Schmidt, Peasants, Traders and Wives, 24.

${ }^{329}$ Gina Buijs, "Gender and Person in African Societies: The Role of Hermeneutics," Alternation, 9, no. 1 (2002): 59 on Hugh Stayt, "Gender and Personhood," in The BaVenda (Oxford: Oxford University Press, 1931), 196-97.

${ }^{330}$ Beach, Shona and Zimbabwe, 91, Thomas N. Huffman, Snakes and Crocodiles: Power and Symbolism in Ancient Zimbabwe (Johannesburg: Wits University Press, 1996), 93.

${ }^{331}$ Beach, Shona and Zimbabwe, 90.
} 
society was significantly nearer to gender parity than Susan Kent's (among others') theory of the inverse relationship between sociopolitical complexity and egalitarianism would suggest it should be. I have not ignored contrary evidence, such as the overtly or barely concealed suppressive rhetoric or the fact that women rarely are supreme authorities, however, in the context of the other evidence, it is these features which seem anomalous and it is therefore these features the paper has sought to explain. ${ }^{332}$ Notably, these explanations have not been dismissive either: in explaining, I have attempted not to 'explain away.' These features are as meaningful as the others, and are clear indicators of male dominance. The only contention of this thesis is that they fail to tell the whole story, as some scholars have seemed to suggest they do.

vaKaranga males did not all accept women's status. The sense that he was consenting in the power over him of a creature he could easily dominate by the methods vaKaranga men (and indeed all human men) employed to coerce other men, somehow seems to have destabilized some men's sense of self. This is the most likely reason that superficial markers sometimes exaggerated the imbalance of gender authority. Basically, I'm suggesting that women's status simply challenged the male ego, explaining rhetorical statements like the one that women do not count, or that men should have horns. ${ }^{333}$

The historical record shows other instances of males challenging the power of women, most notably the succession struggle in Dande recounted by

\footnotetext{
${ }^{332}$ dos Santos, Ethiopia Oriental, 1:12 in Theal, Records VII, 207; Schmidt, Peasants, Traders and Wives, 23.

${ }^{333}$ Schmidt, Peasants, Traders and Wives, 15; dos Santos, Ethiopia Oriental, 1:12 in Theal, Records VII, 207.
} 
dos Santos. ${ }^{334}$ However, it more often shows women manipulating legitimate mechanisms of authority without visible resistance. In fact, the complete dissipation of support for the claimant-who goes beyond challenging the political decision of the wives to implicitly challenging the gender regime-is a powerful indicator of the widespread legitimacy of the non-physical coercive powers women wield. ${ }^{335}$ The breaking point for his supporters with regard to the social contract, we see, is not his challenge to the succession, but his violation of the sanctity of the wives' authority to grant entrance to their space (and, following Monclaro, perhaps their right to consent to their marriage). ${ }^{336}$ It is only then that these traitors, who took up arms against the reigning, if usurping, sovereign, again switched sides and gave themselves up to the usurper or fled.

I discussed at some length the roles of Mutapa queens, as recorded by Bocarro, de Faria e Sousa and the evidence of d'Anhaya's order showing that other vaKaranga queens acted as trade ministers and diplomats. ${ }^{337}$ I then discussed women's production roles in the economy, and the fact that women tended to manage other women's labor. ${ }^{338}$

\footnotetext{
${ }^{334}$ dos Santos, Ethiopia Oriental, 1:5-6 in Theal, Records VII, 193.

${ }^{335}$ Most notably that of sexual witchcraft, see Fr. Francisco Monclaro, Account of the Journey Made by Fathers of the Company of Jesus with Francisco Barreto in the Conquest of Monomotapa in the Year 1569 in Theal, Records III, 229; and Schmidt, Peasants, Traders and Wives, 26.

${ }^{336}$ Monclaro, Account in Theal, Records III, 230.

${ }^{337}$ Antonio Bocarro, Decada Composto por Antonio Bocarro: Chronista de Sua Magestade, do Estado da India, do Feitos dos Portuguezes no Oriente, Capitulo CXXIII in Theal, Records III, 357-58; Manuel de Faria e Sousa, Asia Portuguesa, 2:3:15 in Theal, Records I, 24; Pero d'Anhaya, "An Order from Pero de Anhaia, Captain-Major of Sofala, to the King's Treasurers, 1506 January 7" in Antonio da Silva Rego, ed., Documentos Sobre os Portugueses em Moçambique e na África Central I, trans. T. W. Baxter (Lisbon: National Archives of Rhodesia and Nyasaland, 1962), 367.

${ }^{338}$ Bocarro, Decada Capitulo CXXIII in Theal, Records III, 358; de Faria e Sousa, Asia Portuguesa 2:3:15, in Theal, Records I, 24; João de Barros, Da Asia: Dos Feitos Que os Portugueses Fizeram na Conquista e Descubrimento das Terras e Mres do Oriente, in Theal,
} 
A difference existed, I showed, between the exchange of non-human commodities for a wife, and a sale, and this was not the only context in which people changed hands in exchange for economic value, but in the record, only the unmarried were subject to such exchanges. ${ }^{339}$ This included, in a sense, the wife, with her status as unmarried ending when she arrived in her husband's home, at which point she was no longer subject to exchange. This led into a discussion of the relative and concrete values of women in the marketplace. While an unmarried male child would be worth his lifetime in work value, a female child was worth that as well as the work values of all the children she would bear in that lifetime, making her a 'force multiplier' that was evident in the numbers of livestock men were willing to trade for a single wife. ${ }^{340}$

Discussion of marriage led quickly into an illustration of the ways that Portuguese attitudes distorted the record from the very first word written. Much was shown to be useful in this regard as well, however. Disproportionate numbers of daughters were shown to be a means of social mobility, however, the disparity in economic values by gender does not appear in the literature to have led to gendered population control measures, nor does population control appear in the record in other ways. ${ }^{341}$ The 'inheritance' of wives by surviving brothers was more an indication of the corporate structure of the clan than a commoditization of the woman herself. ${ }^{342}$

Records, VI, 269, 272.

${ }^{339}$ André Fernandes to the Jesuits in Portugal, 5 December, 1562 in Theal, Records II, 145. 340 dos Santos, Ethiopia Oriental, 1:15 in Theal, Records VII, 212; Fernandes to the Jesuits of Portugal in Theal, Records II, 143.

${ }^{341}$ Excepting self-exposure by the elderly, dos Santos, Ethiopia Oriental, 1:15 in Theal, Records VII, 212.

${ }^{342}$ Fr. Dom Gonçalo Silveira, Letter to the Jesuits of the College at Goa in Theal, Records II, 94. 
A more generalized discussion of sexuality followed, starting with taboos against premarital and pre-pubescent sex, and the practice of celibate clientship among young elite males. ${ }^{343}$ Adultery was a capital crime, punishable for both partners, and incest was discussed in the context of clan totems as guarantors of genetic diversity. ${ }^{344}$ Further detail on the practice of royal incest was pursued, noting that it served to preserve the territorial integrity of the mWene's holdings by putting most royal land under the control of his sisters. ${ }^{345}$ Forbidding this practice to non-royals was suggested to be a means of keeping control of rivals' lands in constant flux. ${ }^{346}$

Women in the historical record had space set aside as their own in the concrete world of the royal compound, and in addition to had space set aside for them in the metaphysical realm of the settlement layout. ${ }^{347}$ Furthermore, they were in complete control of the royal compound during interregna. ${ }^{348}$

While it was accepted as a general rule that the statement that women did not accompany war parties was true, it was also noted that one (apparently mistaken) source claims women formed an elite standing military force, and three others describe a woman n'anga (or, possibly, a witch) accompanying the Mongaze army in a major engagement. ${ }^{349}$ Women's control of their appearance

\footnotetext{
${ }^{343}$ André Fernandes to the Jesuits in Portugal in Theal, Records II, 143; Damião de Goes, Chronica do Felicissimo Rei Dom Emanuel da Gloriosa Memoria (Chronicle of King Emanuel), 2:10 in Theal, Records III, 129-30; de Faria e Sousa, Asia Portuguesa, 2:3:15 in Theal, Records I, 23.

${ }^{344}$ de Barros, Da Asia, 1:10:1 in Theal, Records VI, 269.

${ }^{345}$ Beach, Shona and Zimbabwe, 90, 96.

${ }^{346}$ dos Santos, Ethiopia Oriental, 1:5, in Theal, Records, VII, 191.

${ }^{347}$ Thomas Huffman, "Archaeology and Ethnohistory;" Bocarro, Decada Capiltulo CXXII in Theal, Records III, 356; de Faria e Sousa, Asia Portuguesa, 2:3:15, in Theal, Records, 23.

${ }_{348}$ dos Santos, Ethiopia Oriental, 1:5 in Theal, Records VII, 192-93.

${ }^{349}$ Duarte Barbosa, Livro em que Dá Relacão do que Viu e Ouviu no Oriente (manuscript) in
} 
and dress is noted as a minor point with rather substantial testimony in the record, with their greater use of expensive metal and bead accessories a particular point of note..$^{350}$

The outward displays of respect for women in vaKaranga society are treated as issues of space, for lack of a better place to discuss them. ${ }^{351}$ The episode of Rodrigo Lobo killing a lion, among other accounts, suggest that these superficial features are indicative of substantive respect rather than false optics masking deeper-seated objectification. ${ }^{352}$

Lamentably, there was little in the historical record that could add to our understanding of women's places in religion, except to suggest that slight degrees of magnitude are indicated in the severity of taboo violations, and that consensual premarital sex was less severely censured than pre-pubescent virginity was protected. ${ }^{353}$

vaKaranga queens do not appear to have had the power to name their own successors, however they were widely seen and attested as important and influential advisors to sovereigns. ${ }^{354}$ Their status was great enough to overcome

Theal, Records I, 96; de Barros, Da Asia, 1:10:1 in Theal, Records VI, 272; de Faria e Sousa, Asia Portuguesa, 2:3:16, in Theal, Records I, 27; Diogo de Couto, Da Asia: Of the Deeds Which the Portuguese Performed in the Conquest and Discovery of the Lands and Seas of the East Capitulo XXIII in Theal, Records VI, 376; dos Santos, Ethiopia Oriental 2:6, in Theal, Records VII, 263; Monclaro, Account in Theal, Records, III, 243.

${ }^{350}$ de Barros, Da Asia, 1:10:1 in Theal, Records VI, 270; Monclaro, Account in Theal, Records III, 229; André Fernandes to Luiz Froes at Goa in Theal, Records II, 75-76; Barbosa, Livro, in Theal, Records I, 95; dos Santos, Ethiopia Oriental, 1:12 in Theal, Records VII, 207.

${ }^{351}$ de Barros, Da Asia, 1:10:1 in Theal, Records VI, 272.

352 dos Santos, Ethiopia Oriental, 1:20 in Theal, Records VII, 225-27.

${ }^{353}$ de Goes, Chronicle of King Manuel in Theal, Records III, 129; André Fernandes to the Jesuits in Portugal in Theal, Records II, 143.

${ }^{354}$ Bocarro, Decada Capiltulo CXXII in Theal, Records III, 357-58; de Faria e Sousa, Asia Portuguesa, 2:3:15, in Theal, Records, 24; Luiz Froes, "Of the Voyage of the Father Dom Gonçalo to the Kingdom of Monomotapa and of his Happy Passing Away," in Theal, Records II, 120. 
the most overt physical coercion, in certain circumstances, and we saw the critical role the former sovereign's wives collectively played in a disputed succession. ${ }^{355}$ The episode that illustrated this showed more, however, than a formal role in a catalytic decision that only came about every few years. The power of these queens was not protected by any physical or structural thing, but rather by some intangible social contract that, when broken, caused such scandal that the widely popular chosen heir of the seDanda precipitously lost legitimacy and was abandoned by the majority of his supporters.

What this suggests is that the metaphysical potency of the feminine half of the spirit world was so feared that violations of taboos protecting feminine perquisites become almost as impossible socially as violations of physics or biology are. This is a dynamic seen in many of Herbert's 'transformational' activities, in which female spiritual proximity to men, particularly when the womb is active, as during menstruation or childbirth, is considered dangerous to the success of the metaphysical masculine action being carried out, or to the man himself. ${ }^{356}$ The apparent inevitability of the melting away of the chosen claimant's power is astounding, given the confidence he seems to have had in his physical and political support in going into the royal compound.

The social hierarchy of vaKaranga society is clearly gendered, and the pinnacle is, as a rule, a position reserved for a man. Below this rank, however, power is negotiated between gender and status in a stepped pyramid that zigzags back and forth between the genders, with the wives of higher ranking males

\footnotetext{
${ }^{355}$ dos Santos, Ethiopia Oriental, 1:5 in Theal, Records VII, 192-93.

${ }^{356}$ Eugenia Herbert, Iron, Gender and Power: Rituals of Transformation in African Societies (Bloomington: Indiana University Press, 1993), 221.
} 
equal or higher in power to their counterparts, their husbands' immediate inferiors. This social structure functions all the way down to the 'peasant' level, where married women compare on roughly equal terms with unmarried men. Only unmarried women have a lower formal status, and they occupy an inverse place in which their insouciance inspires fear and a sort of dark notoriety that other women, in particular, find fascinating. ${ }^{357}$

Yes, it must be admitted that these positions are determined by the marriage, however in a society that has already institutionalized elitism, most pairings are predetermined by position and status. Romance and marriage were as strange concepts in vaKaranga society at the time as they were elsewhere in the world, perhaps less so, slightly, because a man with the resources for a second wife can afford (both economically and anthropologically) to pay her court. This makes marriage an opportunity for clan-wide social mobility, not only for the woman's family, who stand to gain materially from the exchange, but for the woman herself, who has the opportunity to find a marriage into an economic role suited to her talents and thrive, or even to marry a man of a wealthier clan and live the life of a richer woman than her own mother, have sons and daughters who live wealthier lives. In fact, given the circumstances, it is essentially to be expected that, as wealthier men had geometrically more wives than their subordinates, marriages generally sent women into better socioeconomic circumstances than life with their own clans, who would need the raw commodities more than they needed a pair of hands and no usable womb.

${ }^{357}$ J. R. Crawford, Witchcraft and Sorcery in Rhodesia (Oxford: Oxford University Press, 1967), 60. 
So if vaKaranga society can be said to have been a house of cards, with different suits for the different non-monetized commodities clans probably specialized in producing (I say this from intuition, not from any evidence), then we must acknowledge that the top card was always a king, as far as the record, which is not useless on this point, is concerned, although a queen-sovereign might theoretically have occurred or been permitted to occur if it did transpire. ${ }^{358}$ Immediately below the king card, in this house, is a row made up either entirely, or substantially of queen cards, with 'jacks' either beneath them or the other type interspersed. The metaphor cannot be extended to the commons, unfortunately, but the structure did so, with the wives of the jacks above or interspersed with commoner men according to the same basic pattern as the queens to the jacks, presumably. This is, at any rate, the way things look from the perspective of the elite women this thesis has mainly dealt with. If the structure is more complex, or different entirely, from this, it will likely be because a funded field study has been able to do what this study could not, which is to thoroughly pursue available avenues of primary source information. Barring some drastic reordering of the evidence in that light, however, women's lives in vaKaranga society appear, from the earliest documentary evidence, to be part of a regime that furnishes them with measurable independent status and power.

${ }^{358}$ Beach, Shona and Zimbabwe, 59-60. 
Bibliography:

\section{Primary sources:}

de Anhaia, Pero. 31 January, 1506. An Order from Pero de Anhaia, CaptainMajor of Sofala, to the King's Treasures, at Sofala, 1506 January 31. In Documentos Sobre os Portugueses em Moçambique e na Africa Central Vol. 1. edited by Antonio da Silva Rego, translated by T.W. Baxter, 385-87. Lisbon: National Archives of Rhodesia and Nyasaland, 1962.

Buzurg ibn-Shahriyar, The Book of the Wonders of India: Mainland, Sea and Islands, trans. G.S.P. Freeman-Grenville (London: East-West Publications, Ltd., 1981).

General Act of the Conference of Berlin Concerning the Congo. The American Journal of International Law Vol. 3, No. 1, Supplement: Official Documents (Jan., 1909): 7-25.

Strong, S. A. ed., "Kitab al-Sulwa fi akhbar Kulwa," Journal of the Royal Asiatic Society, LVII (1895)

Theal, George McCall. Kaffir Folk-Lore: A Selection from the Traditional Tales Current Among the People Living on the Eastern Border of the Cape Colony. London: S. Sonnenschein, Le Bas \& Lowery, 1886.

Tracey, Hugh. The Lion on the Path: and Other African Stories. London: Routledge \& Kegan Paul, 1967.

The following archival records, some originally published in manuscript form, others never published, were reprinted in-full in: Records of South-Eastern Africa: Collected in Various Libraries and Archive Departments in Europe. 9 Vol. edited \& translated by George A. Theal. London: William Clowes and Sons, 1899-1903.

Vol. 1: Barbosa, Duarte. Completed 1516, first published 1813. Livro em que dá relacão do que viu e ouviu no Oriente. Lisbon: Academia das Ciências de Lisboa, 85-99.

de Faria e Sousa, Manuel. 1666 \& 1674. Asia Portuguesa. 3 vols. Lisbon: $1-46$.

Vol. 2: Caiado, Antonio. Last week of March, 1561. Letter written by Antonio Caiado from Monomotapa to one of his friends in another part of the same country. Zimbabwe ya Mutapa, Present-day Zimbabwe-Moçambique border: 99-104. 
da Silveira, (Father Dom) Gonçalo. 9 August, 1560. Letter from the Father Dom Gonçalo da Silveira to the Fathers and Brothers of the College at Goa. (llha de) Moçambique: 88-96.

Fernandes, (Father) André. 24 June, 1560. Letter from André Fernandes to the Father Provincial in India. Otonge, Present-Day Moçambique: 5568.

--- 25 June, 1560. Letter from André Fernandes to the Brother Luiz Froes at the College of Goa. Otonge, Present-Day Moçambique: 68-77.

--- 26 June, 1560. Letter from André Fernandes to the Fathers and Brothers of the College at Goa. Otonge, Present-Day Moçambique: 77-88.

---5 December, 1562. Letter from the Father André Fernandes to the Brothers and Fathers of the Society of Jesus in Portugal. Goa: 129-52.

Froes, Luiz. 15 December, 1561. Of the Voyage of the Father Dom Gonçalo to the Kingdom of Monomotapa and of his happy passing away. Goa: College of St. Paul, 104-28.

Vol. 3: Bocarro, Antonio. c. 1649. Decada: His Majesty's Cronicle for the State of India of the Performances of the Portuguese in the East. Lisbon: Academia das Ciências de Lisboa, 254-435.

de Goes, Damião. 1566 Chronicle of the Most Fortunate King Emanuel of Glorious Memory. Lisbon: 1-142.

Monclaro, (Father) Francisco. After 1569. Account of the Journey Made by the Fathers of the Company of Jesus with Francisco Barreto in the Conquest of Monomotapa in the Year 1569. 157-253.

Vol. 6: de Barros, João. 1552. Da Asia: Dos Feitos que os Portuguezes Fizeram na Conquista e Descubrímento des Terras e Mares do Oriente. Vol. 1. Lisbon: 1-306.

de Couto, Diogo. Before 1616. Of Asia: Of the Achievements Made by the Portuguese in the Conquest and Discovery of the Lands and Seas of the Orient. Lisbon: 307-410.

Vol. 7: dos Santos, (Father) João. 1609. Ethiopia Oriental. Evora: The Society of St. Dominic, 1-370. 


\section{Secondary sources:}

Abraham, D.P. "The Early Political History of the Kingdom of Mwene Mutapa, 850-1589." In Historians in Tropical Africa: Proceedings of the Leverhulme Inter-collegiate History Conference. Salisbury: University College of Rhodesia and Nyasaland, 1962.

Amadiume, Ifi. Male Daughters, Female Husbands: Gender and Sex in an African Society. London: Zed Books, 1987.

--- Reinventing Africa: Matriarchy, Religion and Culture. London: Zed Books, 1997.

Beach, David. The Shona and Zimbabwe 900-1850: An Outline of Shona History. London: Heinemann, 1980.

Bent, James Theodore. The Ruined Cities of Mashonaland: Being a Record of Excavation and Exploration in 1891. London: Longmans, Green, and Co., 1896.

Berger, Iris. "Women in East and Southern Africa" In Women in Sub-Saharan Africa: Restoring Women to History, edited by Iris Berger and E. Frances White, 5-61. Bloomington: Indiana University Press, 1999.

Bourdillon, Michael. The Shona Peoples. Gwelo: Mambo Press, 1976.

Buijs, Gina. "Gender and Person in African Societies: The Role of Hermeneutics." Alternation, 9 , no. 1 (2002): 57-73.

Caton-Thompson, Gertrude. The Zimbabwe Culture: Ruins and Reactions. New York: Negro Universities Press, 1931.

Courville, Cindy. "Re-Examining Patriarchy as a Mode of Production: The Case of Zimbabwe." In Theorizing Black Feminisms: The Visionary Pragmatism of Black Women, edited by Stanlie James and Abena Busia, 31-49. London: Routlege, 1993.

Crawford, J. R. Witchcraft and Sorcery in Rhodesia. Oxford: Oxford University Press, 1967.

Ehret, Christopher. An African Classical Age: Eastern and Southern Africa in World History, 1000 B.C. to A.D. 400. Charlotsville: University Press of Virginia, 1998.

Ferreira Duarte, João. "The Politics of Non-Translation: A Case Study in Anglo- 
Portuguese Relations." TTR : traduction, terminologie, rédaction 13, no. 1 (2000): 95-112.

Fortune, George ed., Ngano, vol. 2. Salisbury: University of Rhodesia, Department of African Languages, 1974.

French Jr, John RP. "Field Experiments: Changing Group Productivity." In Experiments in Social Process: A Symposium on Social Psychology, edited by James Miller, 96-118. New York: McGraw-Hill, 1950.

Gardner, Guy. Mapungubwe: Ancient Bantu Civilization on the Limpopo. Leo Fouché and Pieter Johannes Coertze ed. Pretoria: J. L. Van Schaik, 1963.

Garlake, Peter. Great Zimbabwe. New York: Stein and Day, 1973.

Gelfand, Michael. The African Witch: With Particular Reference to Witchcraft Beliefs and Practice Among the Shona of Rhodesia. Edinburgh: E \& S Livingstone, 1967.

Goody, Jack. "Polygyny, Economy and the Role of Women." In The Character of Kinship, edited by Jack Goody, 175-90. Cambridge: Cambridge University Press, 1974.

Grant, Michael (M.R.). "The Sourcing of Southern African Tin Artefacts." Journal of Archaeological Science 26, no. 8 (1999): 1111-17.

Guy, Jeff. "Gender Oppression in Southern Africa's Precapitalist Societies." In Women and Gender in Southern Africa to 1945, edited by Cheryl Walker, 33-47. Claremont: David Philip Publishers, 1990.

Hall, Martin. The Changing Past: Farmers, Kings and Traders in Southern Africa, 200-1860. Cape Town: David Philip, 1987.

Hall, Richard Nicklin and W. G. Neal. The Ancient Ruins of Rhodesia: Monomotapae Imperium. London: Methuen \& Co., 1904.

Herbert, Eugenia. Iron, Gender and Power: Rituals of Transformation in African Societies. Bloomington: Indiana University Press, 1993.

Huffman, Thomas N. "Expressive Space in the Zimbabwe Culture." Man, New Series, 19, no. 4 (Dec. 1984): 593-612.

--- "Ancient Mining and Zimbabwe." Journal of the South African Institute of Mining and Metallurgy 74, no. 6 (1974): 238-42.

--- "Archaeology and Ethnohistory of the African Iron Age." Annual Review of 
Anthropology, vol. 11 (1982): 133-50.

--- "Where You Are the Girls Gather to Play: The Great Enclosure at Great Zimbabwe." Frontiers: Southern African Archeology Today (1984): 252-65.

--- Snakes and Crocodiles: Power and Symbolism in Ancient Zimbabwe. Johannesburg: Wits University Press, 1996.

Hunt, Nancy Rose. "Placing African Women's History and Locating Gender." Social History 14, no. 3 (October 1989): 359-79.

Kent, Susan ed. Gender in African Prehistory. Walnut Creek: AltaMira Press, 1998.

Hall, Simon. "A Consideration of Gender Relations in the Late Iron Age "Sotho" Sequence of the Western Highveld, South Africa." In Gender, edited by Kent, 235-58.

Kent, Susan. "Gender and Prehistory in Africa." In Gender, edited by Kent, 9-21.

Lane, Paul. "Engendered Spaces and Bodily Practices in the Iron Age of Southern Africa." In Gender, edited by Kent, 179-203.

MacLean, Rachel. "Gendered Technologies and Gendered Activities in the Interlacustrine Early Iron Age." In Gender, edited by Kent, 163-77.

Segobye, Alinah. "Daughters of Cattle: The Significance of Herding in the Growth of Complex Societies in Southern Africa Between the 10th and $15^{\text {th }}$ Centuries AD." In Gender, edited by Kent, 227-33.

Klein, Richard. "The Large Mammals of Southern Africa: Late Pliocene to Recent." In Southern African Prehistory and Paleoenvironments, edited by Richard Klein, 107-46. Rotterdam: A.A. Balkema, 1984.

Kuper, Adam. Wives for Cattle: Bridewealth and Marriage in Southern Africa. London: Routledge \& Kegan Paul, 1982.

Leach, Melissa. "Women's Crops in Women's Spaces: Gender Relations in Mende Rice Farming." In Bush Base: Forest Farm, edited by Elizabeth Croll and David Parkin, 76-95. London: Routledge, Chapman \& Hall, Incorporated, 1992.

Mason, Revil. "Background to the Transvaal Iron Age-New Discoveries in Olifantspoort and Broederstroom," Journal of the South African Institute of Mining and Metallurgy 74 (1974) 
Mazarire, Gerald Chikozho. "'The Politics of the Womb': Women, Politics and the Environment in Precolonial Chivi, Southern Zimbabwe, c.1840 to 1900," Zambezia XXX, no. i (2003): 35-50

Musisi, Nakanyike. "Women, 'Elite Polygyny,' and Buganda State Formation" Signs 12, no. 4, special issue on Women, Family, State and Economy in Africa (Summer 1991): 757-86

Nowell, Charles. The Rose-Colored Map: Portugal's Attempt to Build an African Empire from the Atlantic to the Indian Ocean. Lisbon: Junta de Investigações Científicas do Ultramar, 1982.

Pacheco, Albino Manoel. Uma Viagem de Tete ao Zumbo. Moçambique Imprensa Nacional, 1883.

Phillipson, David. The Later Prehistory of Eastern and Southern Africa. London: Heinemann, 1977.

Phimister, lan. "Pre-colonial Gold Mining in Southern Zambezia: A Reassessment," African Social Research 21 (1976)

Pikirayi, Innocent. The Archaeological Identity of the Mutapa State: Towards an Historical Archaeology of Northern Zimbabwe. Uppsala: Societas Archaeologica Upsaliensis, 1993.

--- The Zimbabwe Culture: Origins and Decline of Southern Zambezian States. Walnut Creek: AltaMira Press, 2001.

Randall-Maclver, David. Medieval Rhodesia. Abingdon: Frank Cass \& Co., 1906.

Rayner, William. The Tribe and Its Successors: An Account of African Traditional Life and European Settlement in Southern Rhodesia. London: Faber and Faber, 1962.

Rodney, Walter. How Europe Underdeveloped Africa. Washington: Howard University Press, 1982.

Schapera, Isaac and Astley John Hilary Goodwin. "Work and Wealth." In The Bantu-Speaking Tribes of South Africa, edited by Isaac Schapera, 143-78. London: Routlege and Kegan Paul, 1937.

Schmidt, Elizabeth. Peasants, Traders and Wives: Shona Women in the History of Zimbabwe, 1870-1939. London: Heinemann, 1992.

Scott, Joan. "Gender: A Useful Category of Historical Analysis," The American 
Historical Review, 91, no. 5 (1986)

Stayt, Hugh. "Gender and Personhood," in The BaVenda. Oxford: Oxford University Press, 1931.

Strobel, Margaret. "African Women," Signs 8, no. 1 (Autumn 1982)

Sudarkasa, Niara. "'The Status of Women' in Indigenous African Societies," Femenist Studies 12, no. 1, (Spring 1986): 91-103

Summers, Roger. Ancient Mining in Rhodesia and Adjacent Areas. Salisbury: Trustees of the National Museums of Rhodesia, 1969.

Van Warmelo, Nicolaas J. and W. M. D. Phophi. Venda Law. Pretoria: Government Printer, 1948.

Vogel, Joseph. "'Ruins in a Wild Land,"' foreward to Innocent Pikirayi, The Zimbabwe Culture: Origins and Decline of Southern Zambezian States. Walnut Creek: AltaMira Press, 2001.

Vogel, Joseph, ed. Encyclopedia of Precolonial Africa: Archeology, History, Languages, Cultures and Environments. Walnut Creek: AltaMira Press, 1997.

Huffman, Thomas N. "Architecture and Settlement Patterns." In Encyclopedia, edited by Vogel, 149-55.

Swan, Lorraine. "Southeastern African Gold Mining and Trade." In Encyclopedia, edited by Vogel, 539-40.

Voigt, Elizabeth. Mapungubwe: An Archaeozoological Interpretation of an Iron Age Community. Pretoria: Transvaal Museum, 1983.

Weissberger, Barbara F. Isabella Rules: Constructing Queenship, Wielding Power. Minneapolis: University of Minnesota Press, 2004. 